Engineer Research and

Development Center

\title{
Documenting Presence and Movements of Piscivorous Birds along the Illinois River and within the Chicago Area Waterway System
}

Michael P. Guilfoyle, Brian S. Dorr, Katie Hanson-Dorr, July 2017

Richard A. Fischer, and Anthony M. Friona

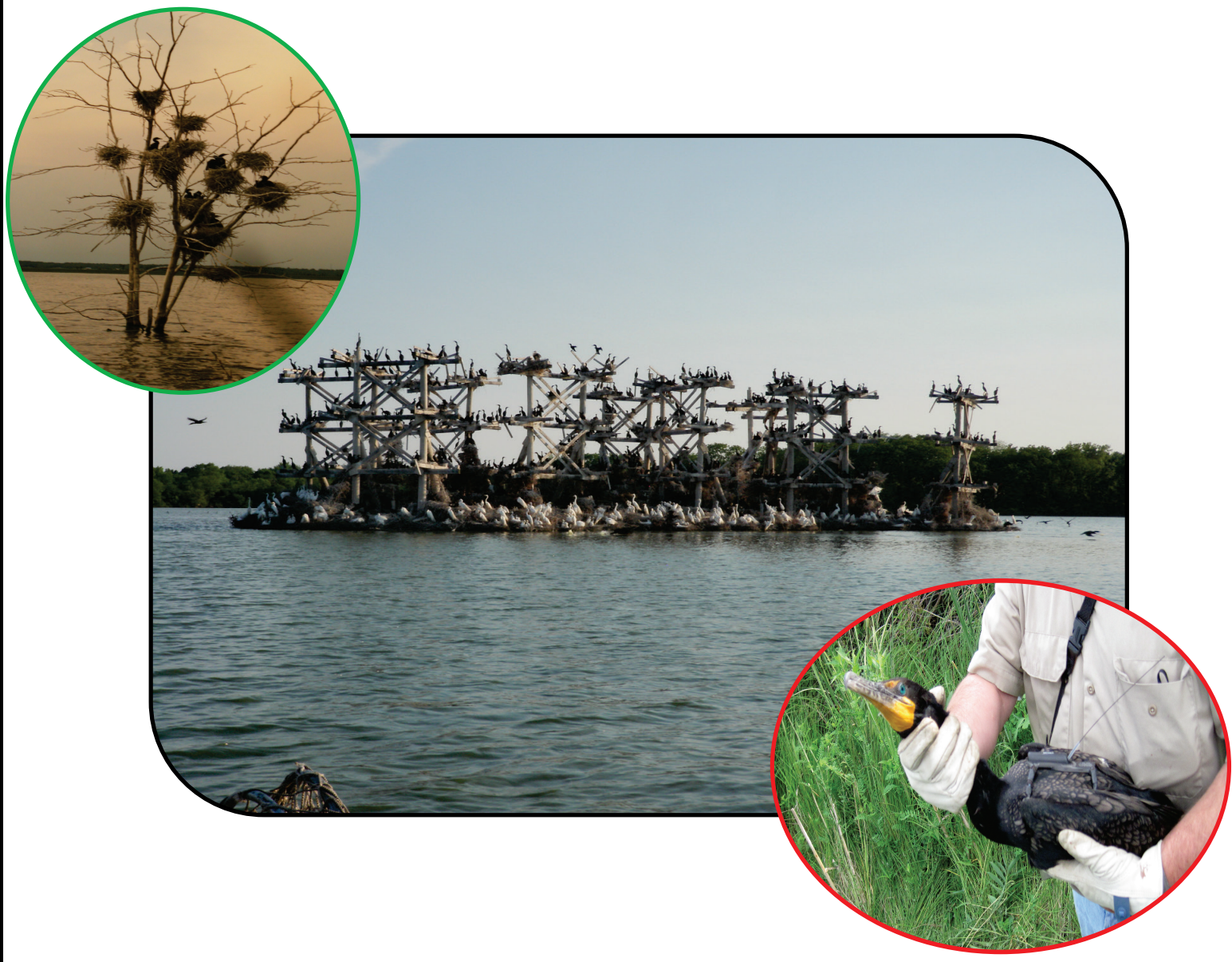


The U.S. Army Engineer Research and Development Center (ERDC) solves the nation's toughest engineering and environmental challenges. ERDC develops innovative solutions in civil and military engineering, geospatial sciences, water resources, and environmental sciences for the Army, the Department of Defense, civilian agencies, and our nation's public good. Find out more at www.erdc.usace.army.mil.

To search for other technical reports published by ERDC, visit the ERDC online library at http://acwc.sdp.sirsi.net/client/default. 


\section{Documenting Presence and Movements of Piscivorous Birds along the Illinois River and within the Chicago Area Waterway System}

Michael P. Guilfoyle, Richard A. Fischer, and Anthony M. Friona

Environmental Laboratory

U.S. Army Engineer Research and Development Center

3909 Halls Ferry Road

Vicksburg, MS 39180-6199

Brian S. Dorr and Katie Hanson-Dorr

USDA Wildlife Services

National Wildlife Research Center

125 Stone Blvd.

Mississippi State University, MS 39762

Final report

Approved for public release; distribution is unlimited.

Prepared for U.S. Army Corps of Engineers

Washington, DC 20314-1000

Under Work Unit 33143

Under Project W81G6612907866, "Asian Carp Environmental DNA Calibration (ECALS) project" 


\section{Abstract}

This technical report summarizes research conducted on piscivorous birds along the Illinois River and in the Chicago Area Waterway System (CAWS) to assess the potential role of these birds as vectors of invasive carp (bighead carp (Hypophthalmichthys noblis) and silver carp (H. molitrix)) DNA (deoxyribonucleic acid). To prevent these carp from invading the Great Lakes, the U.S. Army Corps of Engineers has spent considerable time and resources constructing electrical barriers in the Chicago Sanitary and Ship Canal around Romeoville, IL, just south of the Chicago metropolitan area. Since the construction of these barriers, intensive monitoring of fish populations and invasive carp environmental DNA (eDNA) have been used to document the possible presence of carp above the barrier. The Asian Carp eDNA Calibration Study (ECALS) was designed to improve our understanding and interpretations of eDNA monitoring efforts in the Chicago Area Waterway System (CAWS). Existing online bird population data sources were analyzed, and 30 Double-Crested Cormorants (Phalacrocorax auritus) were captured and satellite-tagged. The results from these projects are evidence that piscivorous birds are likely contributing - at least in part - to the presence of invasive carp DNA in the Chicago Area Waterway System.

DISCLAIMER: The contents of this report are not to be used for advertising, publication, or promotional purposes. Citation of trade names does not constitute an official endorsement or approval of the use of such commercial products. All product names and trademarks cited are the property of their respective owners. The findings of this report are not to be construed as an official Department of the Army position unless so designated by other authorized documents. 


\section{Contents}

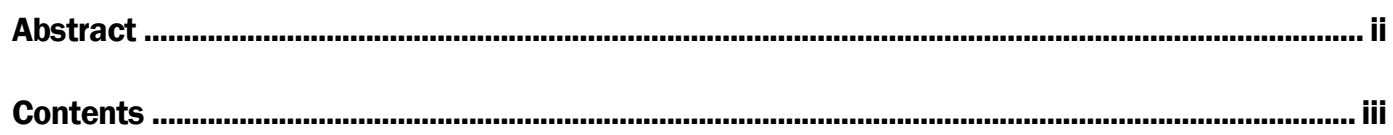

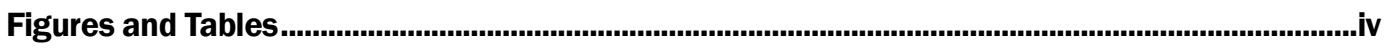

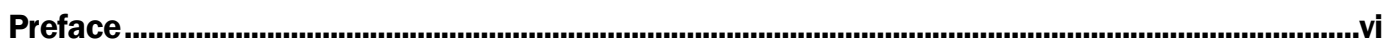

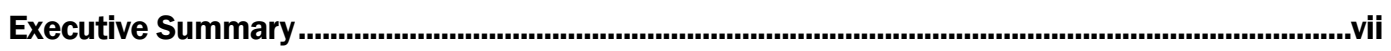

1 Presence of Piscivorous Birds along the Illinois River and in the CAWS

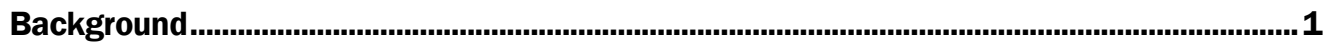

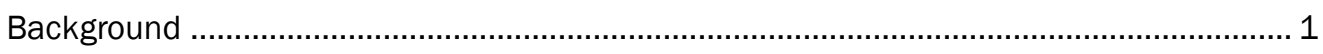

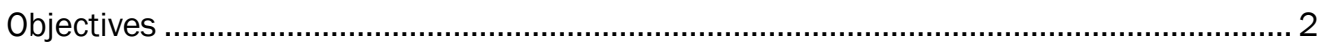

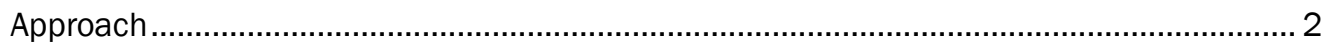

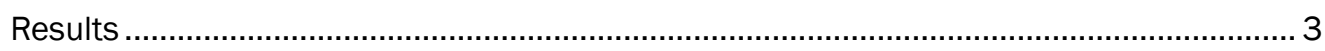

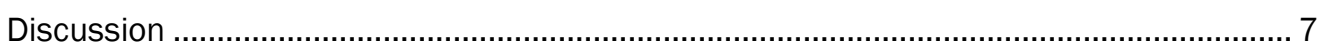

2 Seasonal Movements of the Double-Crested Cormorant along the Illinois River .................. 9

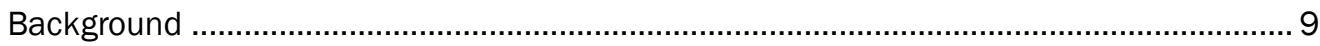

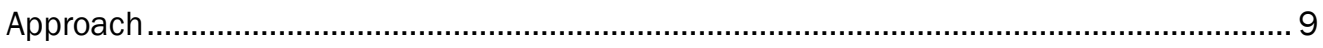

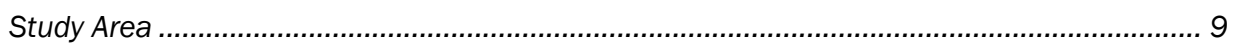

Capture and Tagging of Double-Crested Cormorants ........................................................ 12

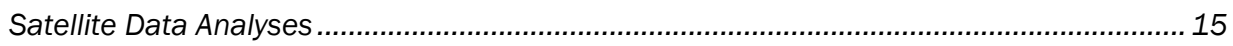

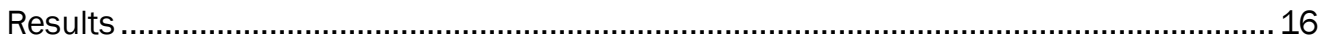

Movements of Satellite Tagged Cormorants ....................................................................... 16

Daily Movements, Bearing, and Home Range Results .................................................... 24

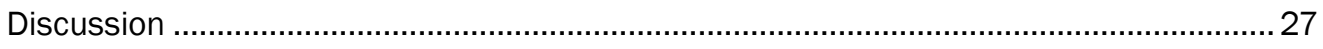

Other Seasonal and Demographic Information about Cormorants ................................... 30

Ideas for Future Research Involving Piscivorous Birds and Asian Carp eDNA ...................... 33

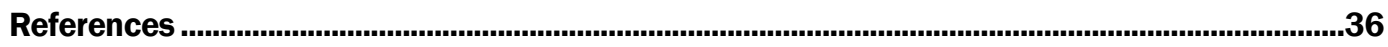

Appendix A: eBird Distributions of the 10 Most Common Piscivorous Birds from

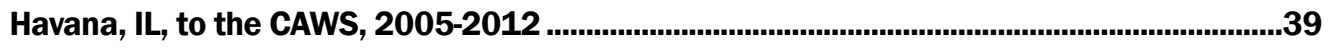

Appendix B Seasonal 95\% and 50\% Kernel Home Range Polygons for All Cormorants

Captured and Tagged at Baker's Lake and the TNC Emiquon Preserve, 2012.

Report Documentation Page 


\section{Figures and Tables}

\section{Figures}

Figure 1. Location of two colonies along the Illinois River and the CAWS where 30 DoubleCrested Cormorants were captured and affixed with satellite transmitter tags in May 2012.

Figure 2. One of several small Double-Crested Cormorant nesting sites found within TNC Emiquon Preserve, near Havana, IL (about $70 \mathrm{~km}$ south of Peoria, IL).

Figure 3. Artificial nesting structure at the Baker's Lake colony site, Barrington, IL.

Figure 4. A USDA/WS/NWRC biologist sets a trap on an active nest of a Double-Crested Cormorant at TNC Emiquon Preserve colony site

Figure 5. A USDA/WS/NWRC biologist records data at the processing station established on the shore of Baker's Lake, May 2012, during efforts to capture and tag Double-Crested Cormorants.

Figure 6. A Sirtrack Argos Satellite PPT transmitter is affixed to a Double-Crested Cormorant at the Baker's Lake colony site, May 2012.

Figure 7. Breeding home range polygons of Double-Crested Cormorant movements from Baker's Lake (blue outline) and the TNC Emiquon Preserve (red outline), May 26 - July 12, 2012.

Figure 8. Migration home range polygons of Double-Crested Cormorant movements from Baker's Lake (blue outline) and the TNC Emiquon Preserve (red outline), July 13 - October 31, 2012.

Figure 9. Wintering home range polygons of Double-Crested Cormorant movements from Baker's Lake (blue outline) and TNC Emiquon Preserve (red outline), November 1 -

December 24, 2012.

Figure A1. Distribution of eBird American White Pelican observations from Havana, IL, to the CAWS, 2005-2012.

Figure A2. Distribution of eBird Double-Crested Cormorant observations from Havana, IL, to the CAWS, 2005-2012.

Figure A3. Distribution of eBird Great Blue Heron observations from Havana, IL, to the CAWS, 2005-2012.

Figure A4. Distribution of eBird Great Egret observations from Havana, IL, to the CAWS, 2005-2012.

Figure A5. Distribution of eBird Snowy Egret observations from Havana, IL, to the CAWS, 2005-2012.

Figure A6. Distribution of eBird Little Blue Heron observations from Havana, IL, to the CAWS, 2005-2012.

Figure A7. Distribution of eBird Green Heron observations from Havana, IL, to the CAWS, 2005-2012.

Figure A8. Distribution of eBird Black-Crowned Night-Heron observations from Havana, IL, to the CAWS, 2005-2012.

Figure A9. Distribution of eBird Bald Eagle observations from Havana, IL, to the CAWS, 2005-012.

Figure A10. Distribution of eBird Osprey observations from Havana, IL, to the CAWS, 2005-2012. 
Figure B1. 95\% kernel home range polygons for 14 breeding cormorants from Baker's Lake, May 26 - July 12, 2012.

Figure B2. 50\% kernel home range polygons for 14 breeding cormorants from Baker's

Lake, May 26 - July 12, 2012.

Figure B3. 95\% kernel home range polygons for 15 breeding cormorants from TNC

Emiquon Preserve, May 26 - July 12, 2012.

Figure B4. 50\% kernel home range polygons for 15 breeding cormorants from TNC

Emiquon Preserve, May 26 - July 12, 2012.

Figure B5. 95\% kernel home range polygons for 8 migrating cormorants from Baker's

Lake, July 12 - October 31, 2012.

Figure B6. 50\% kernel home range polygons for 8 migrating cormorants from Baker's

Lake, July 13 - October 31, 2012.

Figure B7. 95\% kernel home range polygons for 8 migrating cormorants from TNC Emiquon Preserve, July 12 - October 31, 2012.

Figure B8. 50\% kernel home range polygons for 8 migrating cormorants from TNC

Emiquon Preserve, July 12 - October 31, 2012.

Figure B9. 95\% kernel home range polygons for 4 wintering cormorants from Baker's

Lake, November 1 - December 24, 2012.

Figure B10.50\% kernel home range polygons for 4 wintering cormorants from Baker's Lake, November 1 - December 24, 2012.

Figure B11. 95\% kernel home range polygons for 4 wintering cormorants from TNC Emiquon Preserve, November 1 - December 24, 2012.

Figure B12. 50\% kernel home range polygons for 4 wintering cormorants from TNC

Emiquon Preserve, November 1 - December 24, 2012.

\section{Tables}

Table 1. Data downloaded from eBird showing the estimated1 number of observations and number of birds (with mean and standard deviations) for the top ten most abundant piscivorous birds from 2005 to 2012 on three sections of the Illinois and Des Plaines Rivers (Havana to Hennepin, Hennepin to Romeoville, and Romeoville to Chicago). 4

Table 2. Dates and number of observed locations (by season) and movements and fates of all Double-Crested Cormorants captured and fitted with Sirtrack ${ }^{\circledR}$ Argos Satellite PPT tags in 2012.

Table 3. Number of cormorants, total and mean active days, and total and mean number of satellite locations recorded by 30 tagged cormorants from Baker's Lake, Barrington, IL, and TNC Emiquon Preserve, near Havana, IL, 2012.

Table 4. Comparison of mean step distance $(\mathrm{m})$ and bearing of cormorants among seasons within each colony (ANOVA and Tukey's Multiple Range Test) ${ }^{1}$, and comparison of step distance and bearing between colonies (T-Test) ${ }^{2}$

Table 5. Comparison ${ }^{1}$ of seasonal $95 \%$ and $50 \%$ mean kernel home range size $\left(\mathrm{km}^{2}\right)$ and perimeter length $(\mathrm{km})$ among cormorants from Baker's Lake and TNC Preserve.

Table 6. Comparison ${ }^{1}$ of mean step distance $(\mathrm{m})$ and bearing among sexes by season for cormorants the Baker's Lake and TNC Emiquon Preserve.

Table 7. Comparison ${ }^{1}$ of mean $95 \%$ and $50 \%$ mean kernel home range size $\left(\mathrm{km}^{2}\right)$ and perimeter length $(\mathrm{km})$ among sexes for cormorants from the Baker's Lake and TNC 


\section{Preface}

This study was conducted under the Asian carp environmental DNA Calibration (ECALS) project, project number W81G6612907866. This project was a joint effort by the U.S. Army Corps of Engineers (Chicago District), the U.S. Army Research and Development Center, Environmental Laboratory (ERDC-EL), the Environmental Protection Agency (EPA), and the Great Lakes Research Initiative (GLRI) through the Asian Carp Regional Coordinating Committee. Ms. Kelly Baerwaldt was program manager of the research project. Dr. Edmund Russo was the ERDC-EL liaison during the study.

This report was prepared under general guidance of Dr. Richard F. Lance, principle investigator of vectors in the ECALS project, ERDC-EL; Dr. Jennifer Seiter-Moser, Chief, Ecological Resources Branch, ERDC-EL; Mr. Mark Farr, Chief, Ecosystem Evaluation \& Engineering Division, ERDC-EL; Dr. Al Cofrancesco, Technical Director, Civil Works, Environmental Engineering and Sciences, ERDC-EL; and Dr. Beth Fleming, Director, ERDC-EL.

At the time of publication, COL Bryan S. Green was Commander of ERDC, and Dr. David W. Pittman was Director of ERDC. 


\section{Executive Summary}

The Asian Carp Environmental DNA (eDNA) Calibration Study (ECALS) was initiated to better understand the results of eDNA monitoring that was conducted in the Chicago Area Waterway System (CAWS) from 2009 to 2012. Dozens of samples with positive results for invasive carp DNA (Merkes et al. 2014) - yet few to no carp captured during concurrent fish monitoring efforts - deserve an explanation. One possible explanation is the accumulation of invasive carp DNA through foraging and fecal deposition behaviors by piscivorous birds in the region. This report details results from research conducted between 2012 and 2013 that examines the potential role of piscivorous birds as potential vectors of invasive carp DNA in the CAWS. Chapter 1 presents the results of an analysis of bird observation data downloaded for the years 2005 to 2012 from eBird, an online checklist program used by amateur and professional birders. These data document that tens of thousands of piscivorous birds are utilizing the riverine habitat year-round from Peoria to Chicago, IL. Of the 10 most common piscivorous birds in the region, the Double-Crested Cormorant, was determined to be the most likely species to act as a vector for invasive carp DNA because of its predatory and wandering behavior, and its large regional breeding population. Chapter 2 presents the results of 30 DoubleCrested Cormorants captured and fitted with satellite tags that monitored daily movements from May to December 2012. Fifteen birds were captured at both Baker's Lake in the Chicago metropolitan area, and The Nature Conservancy Emiquon Preserve, approximately $70 \mathrm{~km}$ south of Peoria, IL (near to the northern extent of the invasive carp spawning population). Results of this research show that cormorants move great distances during the breeding season and are likely vectors of invasive carp DNA in the CAWS. Results show that cormorants include invasive carp in their diets; however, movement data from satellites did not provide a clear indication where carp may be incorporated into the diet. More research is needed to provide a more comprehensive understanding of the role that piscivorous birds may have in the deposition of invasive carp DNA into the CAWS. Better seasonal population abundance, distribution, and habitat utilization data are needed, plus a better understanding of when invasive carp are incorporated into the diet, and the proportion of carp in the diet. The number of carp DNA copies deposited daily through fecal deposition, plus degradation rates of this DNA once in the water column, is poorly understood. In addition, the potential role of thousands of migrating or non-breeding cormorants needs to be accounted for in 
existing models of invasive carp DNA deposition rates ${ }^{1}$. A better understanding of piscivorous birds as vectors of invasive carp DNA may provide insights into the effectiveness of the existing electric barriers and other control efforts to prevent the movement of invasive carp into the Great Lakes. Finally, further understanding of secondary sources of target DNA during eDNA monitoring may provide insights into the value and limitations of future eDNA monitoring for other species.

1 Guilfoyle, M. P., and M. T. Schultz. (In review). The contribution of double-crested cormorants (Phalacrocorax auritus) to silver carp (Hypophthalmichthys molitrix) DNA loads in the Chicago Area Waterway System. The Journal of Great Lakes Research. 


\section{Presence of Piscivorous Birds along the Illinois River and in the CAWS Background}

\section{Background}

Invasive carp, including both the bighead carp (Hypophthalmichthys nobilis) and silver carp (H. molitrix), have expanded their ranges since the $1990 \mathrm{os}$ north along the Mississippi, Illinois, and Des Plaines Rivers to approximately $60 \mathrm{~km}$ southwest of Lake Michigan. To prevent the carp from invading the Great Lakes, the U.S. Army Corps of Engineers (USACE) has invested considerable resources establishing an Electric Dispersal Barrier (EDB) System near Romeoville, IL, in the Chicago Sanitary and Ship Canal (CSSC) within the Chicago Area Waterway System (CAWS). This barrier system consists of steel electrodes that generate a DC current, creating an electric field that prevents fish from moving across the barrier (Sparks et al. 2010). A demonstration barrier has been in operation since 2002, and Barriers IIA and IIB became operational in 2009 and 2011, respectively. To test the effectiveness of the barrier system, the USACE, U.S. Fish and Wildlife Service (USFWS), and the U.S. Geological Survey (USGS), have collaborated in establishing monitoring protocols to detect whether carp have moved north of the barrier system. In addition to fish community monitoring, the USACE has invested considerable efforts to monitor environmental DNA (eDNA) by testing water samples for the presence of invasive carp DNA above the barrier system and throughout the CAWS. Only one adult bighead carp and no silver carp have been recorded north of the barrier (Merkes et al. 2014), and no records exist of any established carp populations within the CAWS (U.S. Fish and Wildlife Service (USFWS) 2015). However, between 2009 and 2013, 257 of 5,899 water samples collected in the CAWS were positive for silver carp, and 43 of 5,939 samples were positive for bighead carp (Monitoring and Response Work Group (MRWG 2013).

To understand the role of potential secondary vectors affecting carp eDNA monitoring, the Asian Carp Regional Control Committee (ACRCC) established a framework of major tasks to generate better understanding of eDNA monitoring and the influence of potential eDNA vectors. This report presents results from the Environmental DNA Calibration Study (ECALS) research that tests the potential role of piscivorous birds as vectors of invasive carp eDNA in the CAWS. 


\section{Objectives}

The team had two primary objectives: (1) Document the presence and relative abundance of piscivorous birds along the Illinois River, from The Nature Conservancy (TNC) Emiquon Preserve (approximately $70 \mathrm{~km}$ south of Peoria, IL) north to Romeoville, IL (location of the Dispersal Barrier System) and into the CAWS and (2) Locate, capture, and affix satellite tags on 30 Double-Crested Cormorants (Phalacrocorax auritus) to document seasonal movement patterns and determine their potential role as carp DNA vectors in the CAWS.

\section{Approach}

eBird (http://www.ebird.org) is an online checklist program developed and supported by the Cornell Lab of Ornithology and National Audubon Society. This program permits recreational and professional birders to upload and document bird observations and photographs while birding. These observations contribute to an extremely large database that will serve to provide constant, up-to-date data on the distribution and relative abundance of birds throughout North America. For this project, the team downloaded all seasonal information on ten of the most common piscivorous birds utilizing the CAWS and surrounding region. These birds include the Double-Crested Cormorant, Bald Eagle (Haliaeetus leucocephalus), American White Pelican (Pelecanus erythrorthynchos), Osprey (Pandion haliaetus), Little Blue Heron (Egretta caerula), Green Heron (Butorides virescens), Snowy Egret (Egretta thula), Great Egret (Ardea alba), Great Blue Heron (Ardea herodias), and Black-Crowned Night-Heron (Nycticorax nycticorax) (see Appendix A).

Recorded observations were downloaded from eBird for each season (winter: December-February; spring: March-May; summer: June-August, and fall: September-November) from 2005 until 2012. Only data from specific counties that border or include the Illinois River from Havana, IL, (just south of the TNC Emiquon Preserve) to the CAWS were included. These include Mason, Fulton, Tazewell, Peoria, Woodford, Marshall, Putnam, La Salle, Grundy, Will, Lake and Cook counties. Additionally, these counties were grouped to provide information on piscivorous birds along three main sections of the Illinois River: (1) Havana to Hennepin (includes Mason, Fulton, Tazewell, Peoria, Woodford and Putnam Counties); (2) Hennepin to Romeoville (includes La Salle, Will and Grundy Counties); and (3) Romeoville to Chicago CAWS (includes Cook, 
Dupage, and Lake Counties). Counts provided by eBird potentially encompass the entire county, not simply the river and immediate floodplain habitats. Consequently, online individual observations in the river and immediate floodplain were located and entered manually for the American White Pelican and the Bald Eagle for all sections between 2005 and 2012. Comparing these data with the downloaded county-wide data provided by eBird indicated manually entered data were usually about 20 to $48 \%$ less than the county-wide counts. Therefore, observations along the Illinois River and in the CAWS were conservatively estimated by comparing $35 \%$ of the total observations for each species based on the eBird county-wide counts.

\section{Results}

eBird Data from 2005-2012: An estimated 189,807 piscivorous bird observations were recorded along the Illinois River from 2005 to 2012 (Table 1). The Double-Crested Cormorant was the most common species, with over 70,000 observations, followed closely by the American White Pelican, with over 65,000 observations (Table 1). Greater than 20,000 observations of the Great Blue Heron and the Great Egret were recorded, followed by the Black-crowned Night-Heron $(4,809)$, and the Bald Eagle $(2,904)$ (Table 1). Over 2,700 observations of the Green Heron were recorded, while much fewer observations were recorded for the Osprey (599) and the Little Blue Heron (259); the Snowy Egret was the leastcommon piscivorous bird with only 137 observations during the time period (Table 1).

For most bird species, the spring and the summer seasons had the greatest number of recorded observations. Only the Bald Eagle had the greatest number of observations during the winter season; observation data were too sparse to determine seasonal patterns for the Snowy Egret and the Little Blue Heron (Table 1). Six of 10 species (Double-Crested Cormorant, Great Blue Heron, Great Egret, Little Blue Heron, Green Heron, Black-Crowned Night-Heron, and the Osprey) have more observations recorded in the Romeoville to Chicago section, whereas only the American White Pelican and Snowy Egret had the greatest observations in the Havana to Hennepin section (Table 1). The Great Blue Heron, Great Egret, Green Heron, BlackCrowned Night-Heron, Bald Eagle, and the Osprey had similar counts in the Havana to Hennepin and Hennepin to Romeoville sections relative to the greater counts in the Romeoville to Chicago section. Counts for the Little Blue Heron were least in the Hennepin to Romeoville section (Table 1). 
Table 1. Data downloaded from eBird showing the estimated1 number of observations and number of birds (with mean and standard deviations) for the top ten most abundant piscivorous birds from 2005 to 2012 on three sections of the Illinois and Des Plaines Rivers (Havana to Hennepin, Hennepin to Romeoville, and Romeoville to Chicago).

\begin{tabular}{|c|c|c|c|c|c|c|c|c|c|c|c|c|}
\hline \multirow{2}{*}{$\begin{array}{l}\text { Bird Species } \\
\text { River Section }\end{array}$} & \multicolumn{3}{|c|}{$\begin{array}{c}\text { American White Pelican } \\
\text { (Pelecanidae erythrorrhynchos) }\end{array}$} & \multicolumn{3}{|c|}{$\begin{array}{l}\text { Double-Crested Cormorant } \\
\text { (Phalacrocorax auritus) }\end{array}$} & \multicolumn{3}{|c|}{$\begin{array}{l}\text { Great Blue Heron } \\
\text { (Ardea herodias) }\end{array}$} & \multicolumn{3}{|c|}{$\begin{array}{l}\text { Great Egret } \\
\text { (Ardea alba) }\end{array}$} \\
\hline & $\begin{array}{l}\text { No. } \\
\text { Obs. }\end{array}$ & Sum & Mean \pm STD & $\begin{array}{l}\text { No. } \\
\text { Obs. }\end{array}$ & Sum & Mean \pm STD & $\begin{array}{l}\text { No. } \\
\text { Obs. }\end{array}$ & Sum & Mean+STD & $\begin{array}{l}\text { No. } \\
\text { Obs. }\end{array}$ & Sum & Mean \pm STD \\
\hline $\begin{array}{l}\text { Havana to Hennepin: } \\
\text { Spring }\end{array}$ & 99 & 8,220 & $82.7 \pm 149.0$ & 98 & 4,037 & $41.0 \pm 94.7$ & 221 & 891 & $4.0 \pm 10.7$ & 54 & 433 & $8.0 \pm 17.1$ \\
\hline Summer & 82 & 33,029 & $401.6 \pm 1065.7$ & 111 & 2,929 & $26.3 \pm 57.7$ & 253 & 2,268 & $9.0 \pm 16.4$ & 166 & 6,255 & $37.7 \pm 88.0$ \\
\hline Fall & 97 & 15,729 & $162.8+448.7$ & 72 & 1,832 & $25.3 \pm 78.8$ & 169 & 735 & $4.4 \pm 6.5$ & 89 & 876 & $9.8+21.0$ \\
\hline Winter & 27 & 123 & $13.5 \pm 27.2$ & 5 & 14 & $2.9 \pm 3.5$ & 47 & 193 & $4.1 \pm 7.2$ & $n / a^{2}$ & $n / a$ & $n / a$ \\
\hline Sub-Total & 305 & 57,101 & $198.7 \pm 2798.4$ & 287 & 8,812 & $30.7 \pm 77.3$ & 690 & 4,087 & $5.9 \pm 12.4$ & 309 & 7,564 & $24.5 \pm 67.4$ \\
\hline $\begin{array}{l}\text { Hennepin to Romeoville: } \\
\text { Spring }\end{array}$ & 82 & 4,524 & $55.5 \pm 100.7$ & 236 & 4,715 & $19.9 \pm 95.2$ & 358 & 1,471 & $4.1 \pm 10.7$ & 166 & 1,260 & $7.6 \pm 31.3$ \\
\hline Summer & 41 & 1,451 & $35.7 \pm 51.4$ & 192 & 9,017 & $47.0 \pm 135.0$ & 303 & 1,871 & $6.2 \pm 9.6$ & 224 & 2,392 & $10.7 \pm 25.03$ \\
\hline Fall & 57 & 2,230 & $38.8 \pm 73.1$ & 109 & 6,179 & $56.6 \pm 131.9$ & 186 & 643 & $3.5 \pm 4.3$ & 106 & 725 & $6.9 \pm 13.1$ \\
\hline Winter & 13 & 34 & $2.7 \pm 6.7$ & 50 & 445 & $8.9 \pm 13.4$ & 140 & 427 & $3.0 \pm 5.0$ & $\mathrm{n} / \mathrm{a}$ & $n / a$ & $n / a$ \\
\hline Sub-Total & 193 & 8,239 & $42.9 \pm 81.4$ & 587 & 20,353 & $34.7 \pm 114.5$ & 987 & 4,412 & $4.5 \pm 8.8$ & 496 & 4,377 & $8.8 \pm 25.6$ \\
\hline $\begin{array}{l}\text { Romeoville to Chicago: } \\
\text { Spring }\end{array}$ & 23 & 676 & $29.3+46.6$ & 1,216 & 16,732 & $13.8 \pm 62.4$ & 1,539 & 4,271 & $2.8 \pm 6.0$ & 563 & 1,878 & $3.3 \pm 13.7$ \\
\hline Summer & 9 & 52 & $5.5 \pm 7.4$ & 1,084 & 10,222 & $9.4 \pm 49.9$ & 1,797 & 5,519 & $3.3 \pm 8.8$ & 936 & 5,192 & $5.5 \pm 23.7$ \\
\hline Fall & 9 & 127 & $13.9 \pm 24.5$ & 916 & 14,098 & $15.4 \pm 114.1$ & 918 & 2,057 & $2.2 \pm 5.9$ & 340 & 2,143 & $6.3 \pm 26.5$ \\
\hline Winter & $n / a$ & $\mathrm{n} / \mathrm{a}$ & $n / a$ & 74 & 189 & $2.6 \pm 3.8$ & 165 & 247 & $1.5 \pm 1.5$ & $n / a$ & $n / a$ & $n / a$ \\
\hline Sub-Total & 41 & 855 & $20.5 \pm 37.9$ & 3,290 & 41,241 & $12.5 \pm 76.8$ & 4,419 & 12,094 & $2.8 \pm 7.1$ & 1,839 & 9,213 & $5.0+21.8$ \\
\hline TOTAL & 539 & 66,195 & $127.0 \pm 484.6$ & 4,164 & 70,406 & $17.9 \pm 134.7$ & 6,096 & 20,593 & $3.5 \pm 8.3$ & 2,644 & 21,154 & $8.0 \pm 32.0$ \\
\hline Bird Species & \multicolumn{3}{|c|}{$\begin{array}{l}\text { Snowy Egret } \\
\text { (Egretta thula) }\end{array}$} & \multicolumn{3}{|c|}{$\begin{array}{l}\text { Little Blue Heron } \\
\text { (Egretta caerulea) }\end{array}$} & \multicolumn{3}{|c|}{$\begin{array}{c}\text { Green Heron } \\
\text { (Butorides virescens) }\end{array}$} & \multicolumn{3}{|c|}{$\begin{array}{l}\text { Black-Crowned Night-Heron } \\
\text { (Nycticorax nycticorax) }\end{array}$} \\
\hline River Section & $\begin{array}{l}\text { No. } \\
\text { Obs. }\end{array}$ & Sum & Mean \pm STD & $\begin{array}{l}\text { No. } \\
\text { Obs. }\end{array}$ & Sum & Mean +STD & $\begin{array}{l}\text { No. } \\
\text { Obs. }\end{array}$ & Sum & $\begin{array}{l}\text { Mean } \\
\pm \text { STD }\end{array}$ & $\begin{array}{l}\text { No. } \\
\text { Obs. }\end{array}$ & Sum & Mean \pm STD \\
\hline
\end{tabular}




\begin{tabular}{|c|c|c|c|c|c|c|c|c|c|c|c|c|}
\hline $\begin{array}{l}\text { Havana to Hennepin: } \\
\text { Spring }\end{array}$ & N.S. & N.S. ${ }^{2}$ & N.S. & N.S. & N.S. & N.S. & 32 & 46 & $1.5 \pm 0.8$ & N.S. & N.S. & N.S. \\
\hline Summer & N.S. & N.S. & N.S. & N.S. & N.S. & N.S. & 67 & 118 & $1.8+1.7$ & N.S. & N.S. & N.S. \\
\hline Bird Species & \multicolumn{3}{|c|}{$\begin{array}{l}\text { Snowy Egret } \\
\text { (Egretta thula) }\end{array}$} & \multicolumn{3}{|c|}{$\begin{array}{l}\text { Little Blue Heron } \\
\text { (Egretta caerulea) }\end{array}$} & \multicolumn{3}{|c|}{$\begin{array}{c}\text { Green Heron } \\
\text { (Butorides virescens) }\end{array}$} & \multicolumn{3}{|c|}{$\begin{array}{l}\text { Black-Crowned Night-Heron } \\
\text { (Nycticorax nycticorax) }\end{array}$} \\
\hline River Section & $\begin{array}{l}\text { No. } \\
\text { Obs. }\end{array}$ & Sum & Mean \pm STD & $\begin{array}{l}\text { No. } \\
\text { Obs. }\end{array}$ & Sum & Mean +STD & $\begin{array}{l}\text { No. } \\
\text { Obs. }\end{array}$ & Sum & $\begin{array}{l}\text { Mean } \\
+ \text { STD }\end{array}$ & $\begin{array}{l}\text { No. } \\
\text { Obs. }\end{array}$ & Sum & Mean \pm STD \\
\hline Fall & N.S. & N.S. & N.S. & N.S. & N.S. & N.S. & 8 & 8 & $1.0 \pm 0.6$ & N.S. & N.S. & N.S. \\
\hline Winter & $n / a$ & $n / a$ & $n / a$ & $n / a$ & $n / a$ & $n / a$ & $n / a$ & $n / a$ & $n / a$ & $n / a$ & $n / a$ & $n / a$ \\
\hline Sub-Total & 40 & 100 & $2.5 \pm 23.9$ & 24 & 58 & $2.4 \pm 3.3$ & 107 & 172 & $1.6 \pm 1.4$ & 26 & 64 & $2.5 \pm 1.7$ \\
\hline $\begin{array}{l}\text { Hennepin to Romeoville: } \\
\text { Spring }\end{array}$ & N.S. & N.S. & N.S. & N.S. & N.S. & N.S. & 24 & 26 & $1.1 \pm 0.6$ & 13 & 41 & $3.2 \pm 4.9$ \\
\hline Summer & N.S. & N.S. & N.S. & N.S. & N.S. & N.S. & 92 & 168 & $1.8 \pm 0.6$ & 42 & 88 & $2.1 \pm 1.8$ \\
\hline Fall & N.S. & N.S. & N.S. & N.S. & N.S. & N.S. & 14 & 21 & $1.5 \pm 0.9$ & 21 & 58 & $2.8 \pm 1.9$ \\
\hline Winter & $n / a$ & $n / a$ & $n / a$ & $n / a$ & $n / a$ & $n / a$ & $n / a$ & $n / a$ & $n / a$ & $\mathrm{n} / \mathrm{a}$ & $n / a$ & $n / a$ \\
\hline Sub-Total & 4 & 5 & $1.0 \pm 05$ & 4 & 4 & $0.9 \pm 0.5$ & 130 & 215 & $1.7 \pm 1.5$ & 76 & 187 & $2.5 \pm 2.6$ \\
\hline $\begin{array}{l}\text { Romeoville to Chicago: } \\
\text { Spring }\end{array}$ & N.S. & N.S. & N.S. & 33 & 45 & $1.4 \pm 0.7$ & 584 & 881 & $1.5 \pm 1.3$ & 491 & 2,540 & $5.2 \pm 20.5$ \\
\hline Summer & N.S. & N.S. & N.S. & 84 & 144 & $1.7 \pm 1.5$ & 771 & 1,277 & $1.7 \pm 1.5$ & 492 & 1,695 & $3.4 \pm 9.6$ \\
\hline Fall & N.S. & N.S. & N.S. & $n / a$ & $n / a$ & $n / a$ & 164 & 206 & $1.3 \pm 1.2$ & 170 & 291 & $1.7 \pm 2.1$ \\
\hline Winter & $n / a$ & $n / a$ & $n / a$ & $n / a$ & $n / a$ & $n / a$ & $n / a$ & $n / a$ & $n / a$ & 20 & 32 & $1.6 \pm 0.9$ \\
\hline Sub-Total & 33 & 39 & $1.2 \pm 0.7$ & 122 & 197 & $1.6 \pm 1.3$ & 1,519 & 2,364 & $1.6 \pm 1.4$ & 1,173 & 4,558 & $3.9 \pm 14.7$ \\
\hline TOTAL & 77 & 137 & $1.9 \pm 1.7$ & 150 & 259 & $1.7 \pm 1.8$ & 1,756 & 2,751 & $1.6 \pm 1.4$ & 1,275 & 4,809 & $3.8 \pm 14.1$ \\
\hline Bird Species & \multicolumn{3}{|c|}{$\begin{array}{c}\text { Bald Eagle } \\
\text { (Haliaeetus leucocephalus) }\end{array}$} & \multicolumn{3}{|c|}{$\begin{array}{c}\text { Osprey } \\
\text { (Pandion haliaetus) }\end{array}$} & & & & & & \\
\hline River Section & $\begin{array}{l}\text { No. } \\
\text { Obs. }\end{array}$ & Sum & Mean \pm STD & No. Obs. & Sum & Mean \pm STD & & & & & & \\
\hline $\begin{array}{l}\text { Havana to Hennepin: } \\
\text { Spring }\end{array}$ & 90 & 283 & $3.1 \pm 4.4$ & 10 & 9 & $1.0 \pm 0.4$ & & & & & & \\
\hline Summer & 41 & 88 & $2.1 \pm 2.4$ & 9 & 11 & $1.2 \pm 0.6$ & & & & & & \\
\hline
\end{tabular}




\begin{tabular}{|c|c|c|c|c|c|c|}
\hline \multirow{2}{*}{$\begin{array}{l}\text { Bird Species } \\
\text { River Section }\end{array}$} & \multicolumn{3}{|c|}{$\begin{array}{c}\text { Bald Eagle } \\
\text { (Haliaeetus leucocephalus) }\end{array}$} & \multicolumn{3}{|c|}{$\begin{array}{r}\text { Osprey } \\
\text { (Pandion haliaetus) }\end{array}$} \\
\hline & $\begin{array}{l}\text { No. } \\
\text { Obs. }\end{array}$ & Sum & Mean \pm STD & No. Obs. & Sum & Mean \pm STD \\
\hline Fall & 71 & 208 & $2.9 \pm 3.4$ & 9 & 11 & $1.2 \pm 0.5$ \\
\hline Winter & 114 & 639 & $5.6 \pm 10.6$ & $n / a$ & $n / a$ & $\mathrm{n} / \mathrm{a}$ \\
\hline Sub-Total & 316 & 1,218 & $3.8 \pm 7.1$ & 28 & 31 & $1.1 \pm 0.5$ \\
\hline $\begin{array}{l}\text { Hennepin to Romeoville: } \\
\text { Spring }\end{array}$ & 68 & 111 & $1.6 \pm 1.9$ & 12 & 19 & $1.6 \pm 1.1$ \\
\hline Summer & 26 & 30 & $1.2 \pm 0.6$ & 17 & 22 & $1.3 \pm 0.8$ \\
\hline Fall & 34 & 48 & $1.4 \pm 0.9$ & 13 & 16 & $1.2 \pm 0.6$ \\
\hline Winter & 168 & 1,236 & $7.3 \pm 20.6$ & $n / a$ & $\mathrm{n} / \mathrm{a}$ & $\mathrm{n} / \mathrm{a}$ \\
\hline Sub-Total & 296 & 1,425 & $4.8+15.8$ & 42 & 57 & $1.4 \pm 0.8$ \\
\hline $\begin{array}{l}\text { Romeoville to Chicago: } \\
\text { Spring }\end{array}$ & 50 & 66 & $1.3 \pm 0.9$ & 144 & 175 & $1.2 \pm 0.6$ \\
\hline Summer & 10 & 10 & $1.0 \pm 0.2$ & 130 & 212 & $1.6 \pm 1.2$ \\
\hline Fall & 65 & 90 & $1.4 \pm 1.0$ & 81 & 124 & $1.5 \pm 1.6$ \\
\hline Winter & 73 & 95 & $1.3 \pm 0.6$ & $n / a$ & $n / a$ & $\mathrm{n} / \mathrm{a}$ \\
\hline Sub-Total & 198 & 261 & $1.3 \pm 0.8$ & 355 & 511 & $1.4 \pm 1.1$ \\
\hline TOTAL & 810 & 2,904 & $5.3 \pm 10.6$ & 425 & 599 & $1.9 \pm 1.1$ \\
\hline
\end{tabular}

1 Total numbers and observations for the American white pelican and the bald eagle within the immediate river and adjacent floodplain varied between $20 \%-48 \%$ of the total

numbers/observations for each section (based on total cumulative counts of all

numbers/observations for each county comprising each section); therefore, estimated

numbers and observations presented in this table are based on $35 \%$ of the total

numbers/observation.

${ }^{2}$ N.S.: represents numbers/observations less than 50 per season for any specific section; $n / a$ :

represents seasons when no observation of a species is recorded. 
Although the eBird data included observations throughout all the counties, when the data are projected in ArcMAP, most distributions appear concentrated along the Illinois River and other open water habitats (Appendix A; Figures A1-A10). Numerous small rivers, streams, ponds, and lakes are distributed throughout the Chicago area, which may explain why distributions appear much more dispersed in the CAWS (Appendix A; Figures A1-A10).

\section{Discussion}

During 2005 to 2012, the Double-Crested Cormorant was the most common piscivorous bird in the region during the breeding season, followed closely by the American White Pelican, and other, less common species, including the Great Egret and Great Blue Heron. The Bald Eagle was the most common winter piscivorous species. In general, among the piscivorous birds detected in the Chicago area, the Double-Crested Cormorant is the species most likely to act as a potential vector of Asian carp DNA in the CAWS. Several reasons for this view include: (1) cormorants are aggressive and opportunistic predators of fish (Dorr et al. 2014); (2) cormorants are the most common piscivorous species during the breeding season in the Chicago area (see Table 1); (3) they often make long flights (>30 km) daily (Dorr et al. 2012, King et al. 2012a), increasing the likelihood that they could forage in invasive carp-infested waters and return to the breeding colony; (4) cormorants are well-known for producing large quantities of fecal material in and around nesting colonies; (5) viable carp DNA have been found in cormorant fecal material (ACRCC 2013, 2014; Merkes et al. 2014); and (6) populations within the Chicago area have invasive carp DNA present in throat and cloacal swabs (Guilfoyle et al. 2017). In addition, all other piscivorous birds breeding in the Chicago area have much lower population counts based on the eBird data. The American White Pelican was found to have similar high counts from Havana, IL, to Chicago, IL, but virtually all observation of pelicans were in the Havana to Hennepin section (Table 1). In the Chicago area from 2005 to 2012, only 855 pelicans were observed compared to $>40,000$ cormorants during the same time period (Table 1).

In addition, tens of thousands of cormorants have been observed during spring and fall migration (Table 1). Since birds move from southern wintering areas to northern breeding areas during the spring, migrating cormorants during this period are more likely potential invasive carp DNA vectors since they are probably traveling from invasive carp-infested 
regions. However, fall migrants are traveling from northern regions that currently do not support Asian carp populations and therefore are less likely to act as invasive carp DNA vectors in the CAWS. The role of breeding cormorants as invasive carp DNA vectors are investigated here since breeding birds could potentially travel to and from carp-infested areas on a daily basis. Further research will be needed to evaluate the role of cormorants as carp DNA vectors during the migration seasons ${ }^{1}$ (Guilfoyle et al. 2017).

It is important to note that while eBird provides an important index of relative abundance for various bird species, these data have not been collected under controlled, statistically valid protocols that can provide statistically relevant and repeatable comparisons among species or trends in the region. Additional research into the potential role of the DoubleCrested Cormorant and other piscivorous birds in the region as vectors of invasive carp DNA in the CAWS will require a more comprehensive monitoring program that can provide scientifically verifiable population size estimates, distributions in the region, and daily habitat use by foraging, breeding, and roosting birds (Bart et al. 2012).

\footnotetext{
1 Guilfoyle, M. P., and M. T. Schultz. (In review). The contribution of double-crested cormorants (Phalacrocorax auritus) to silver carp (Hypophthalmichthys molitrix) DNA loads in the Chicago Area Waterway System. The Journal of Great Lakes Research.
} 


\section{Seasonal Movements of the Double- Crested Cormorant along the Illinois River}

\section{Background}

In order to understand the role of potential vectors affecting invasive carp eDNA monitoring, ACRCC established a framework of major tasks to generate better understanding of eDNA monitoring and the influence of potential eDNA vectors. This report presents results from ECALS research that tests the potential role of piscivorous birds as invasive carp DNA vectors in the CAWS. In this activity, the team's objective was to locate, capture, and affix satellite tags on 30 Double-Crested Cormorants to document movement patterns and determine their potential role as invasive carp eDNA vectors in the CAWS during the breeding season. Fifteen of the tagged cormorants were captured at Baker's Lake, a colony north of the Electrical Dispersal Barrier (EDB) by approximately $50 \mathrm{~km}$. This area is largely devoid of invasive carp, with no known spawning activity (USFWS 2015). Therefore, invasive carp is unlikely to be included in the diet of these birds. Another fifteen cormorants were tagged at TNC Emiquon Preserve, located south of Peoria, IL, adjacent to the Illinois River with a known abundant and spawning population of invasive carp (USFWS 2015). Therefore, invasive carp was expected to be a component of the cormorant diet at this colony.

\section{Approach}

\section{Study Area}

From May 25 to May 29, 2012, the team captured 30 Double-Crested cormorants at two locations: 1) TNC Emiquon Preserve approximately $70 \mathrm{~km}$ south of Peoria, IL (Figures 1 and 2), and 2) Baker's Lake, in Barrington, IL, part of the Cook County Forest Preserve (Figure 3). The team eliminated a third site, Lake Renwick (also part of the Cook County Forest Preserve), because it was not possible to obtain permission to access this site. Initially, the team intended to capture and tag 10 birds at each of the three sites; however, 15 birds were captured and tagged at both the TNC Emiquon Preserve and Baker's Lake, respectively. The TNC Emiquon Preserve is located in an area with a large known Asian carp spawning population (USFWS 2015) ${ }^{1}$, while the Baker's Lake site is

\footnotetext{
${ }^{1}$ Baerwaldt, K. L., A. Benson, and K. Irons. 2013. Asian carp distribution in North America. Unpublished report, U.S. Army Corps of Engineers, Chicago District.
} 
located $56 \mathrm{~km}$ north of the EDB, and therefore in an area with few or no recorded Asian carp and no spawning activities (but as part of the Chicago area, this site was located near the CAWS with eDNA samples positive for invasive carp).

Figure 1. Location of two colonies along the Illinois River and the CAWS where 30 Double-Crested Cormorants were captured and affixed with satellite transmitter tags in May 2012.

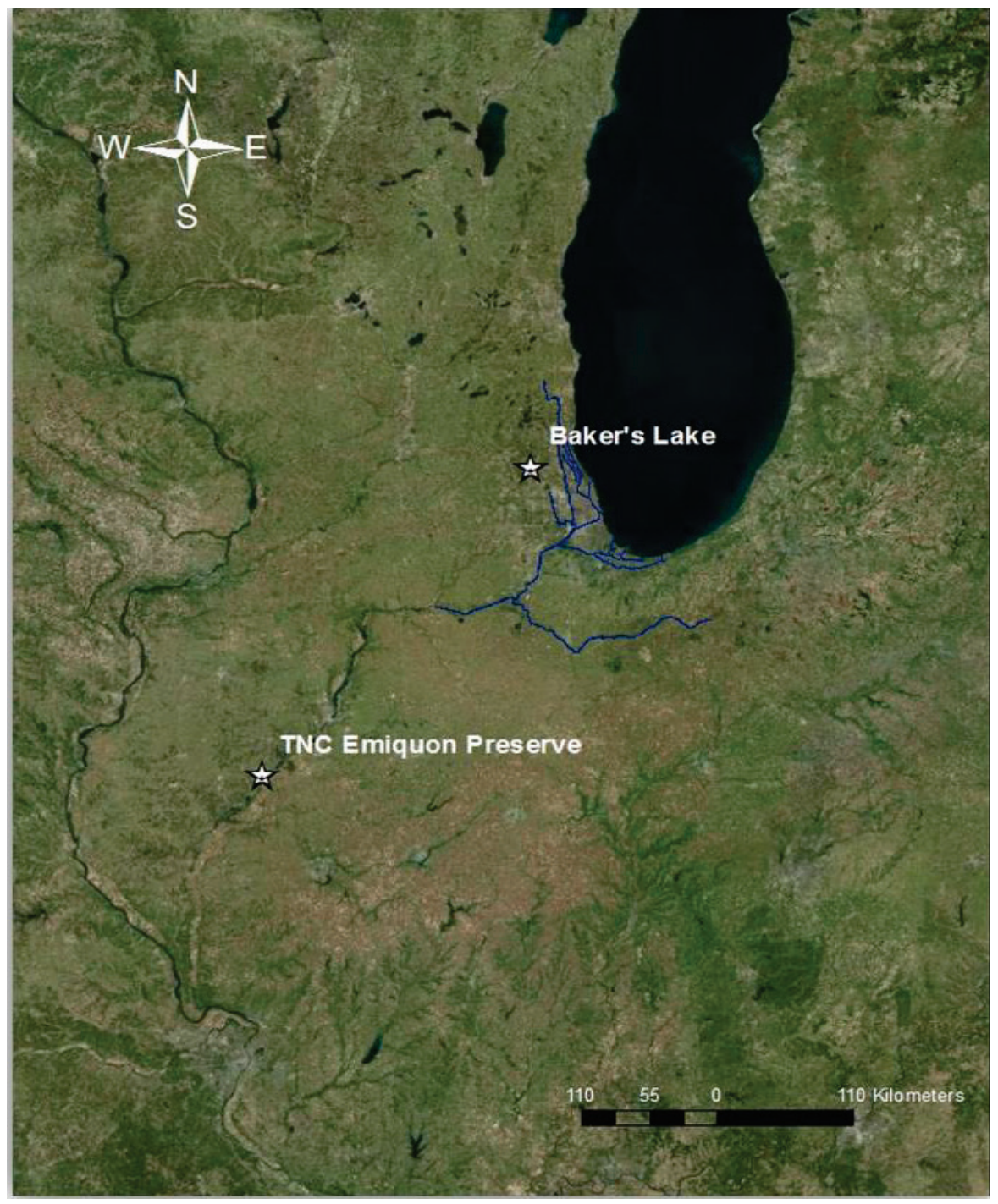


Figure 2. One of several small Double-Crested Cormorant nesting sites found within TNC Emiquon Preserve, near Havana, IL (about $70 \mathrm{~km}$ south of Peoria, IL). 
Figure 3. Artificial nesting structure at the Baker's Lake colony site, Barrington, IL.

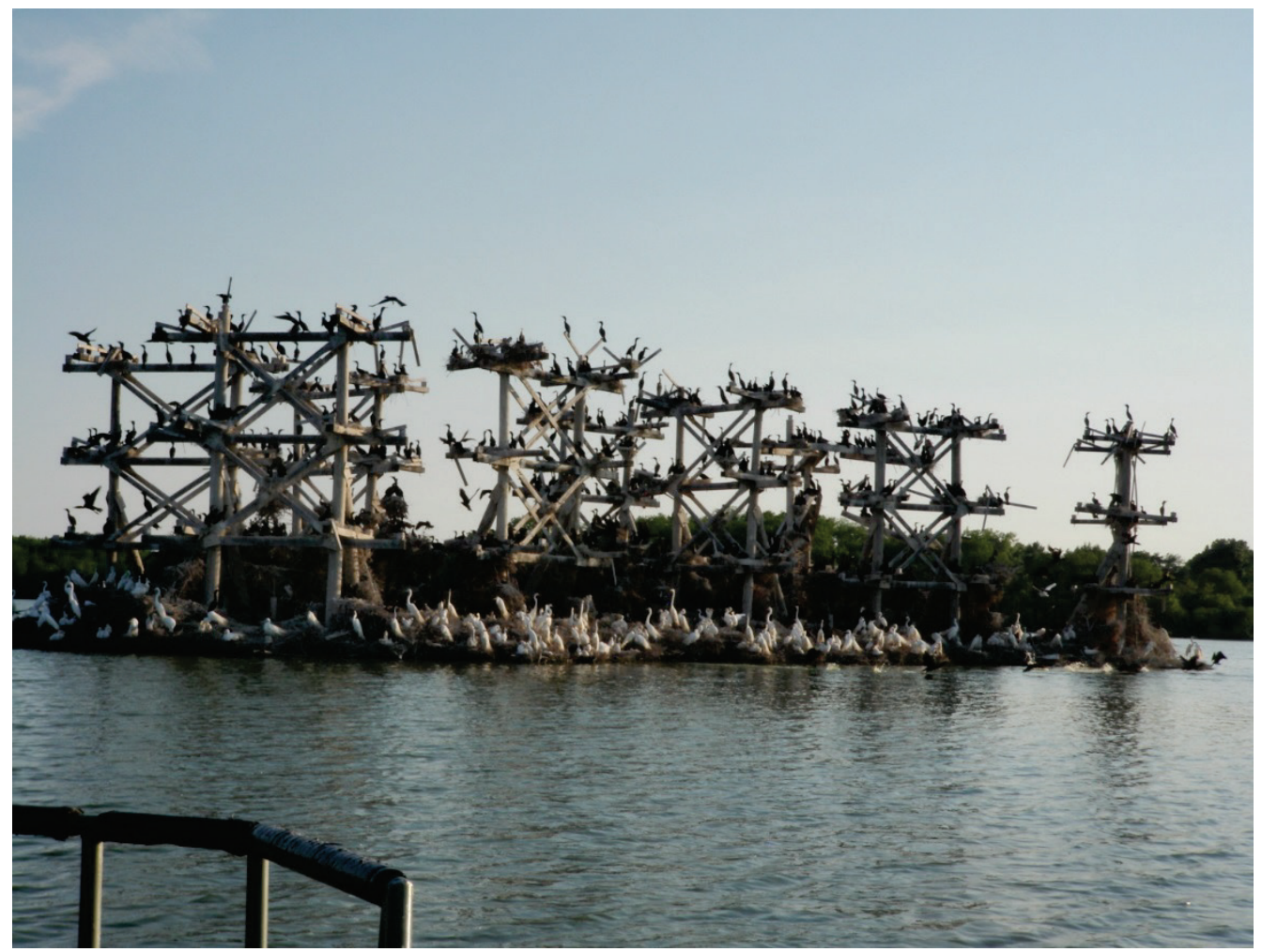

\section{Capture and Tagging of Double-Crested Cormorants}

The team captured birds at colony sites during the breeding season in May 2012. At both sites, the rookeries were either located in trees (TNC Emiquon Preserve; Figure 2) or artificial structures (Baker's Lake; Figure 3). The team used a small boat to travel to the rookery site, where No. 3 Victor $\AA$ Softcatch padded coil spring traps were used. These traps were modified with weaker springs to reduce the initial impacts of the padded jaws and minimize any potential harm to the birds (King and Tobin 2000). Traps were placed directly on an active nest, immediately adjacent to an active nest, or in the vicinity of an active nest (Figure 4). After trap placement, the team moved away from the rookery (usually about 50-100 $\mathrm{m}$ ) and observed the traps until a capture was detected (rarely more than 10 or 15 min after trap placement). After capture, the bird was freed from the trap, placed in a burlap sack, and processed by collecting specific data: total weight $(\mathrm{kg})$, wing chord (mm), culmen length ( $\mathrm{mm}$ ) and tarsus length (mm) (Figure 5). The team also used cotton swabs to collect DNA material from the throat and cloaca; plus, a tail and three breast feathers were collected. These samples were used to test for the presence of invasive carp DNA; plus cormorant DNA in feathers was used to sex the birds (results presented in Guilfoyle et al. 2017). The team placed all samples into vials that were 
marked with the date, time, cormorant ID number, and colony. After processing, the team released all birds onsite. Cormorant capture efforts were conducted with permits through the U.S. Department of Agriculture, Wildlife Services (USDA-WS), National Wildlife Research Center's (NWRC) Institutional Animal Care and Use Committee Protocol QA-2003 and the U.S. Department of Interior, U.S. Geological Survey, Federal Bird Banding Permit 20873.

Figure 4. A USDA/WS/NWRC biologist sets a trap on an active nest of a Double-Crested Cormorant at TNC Emiquon Preserve colony site.

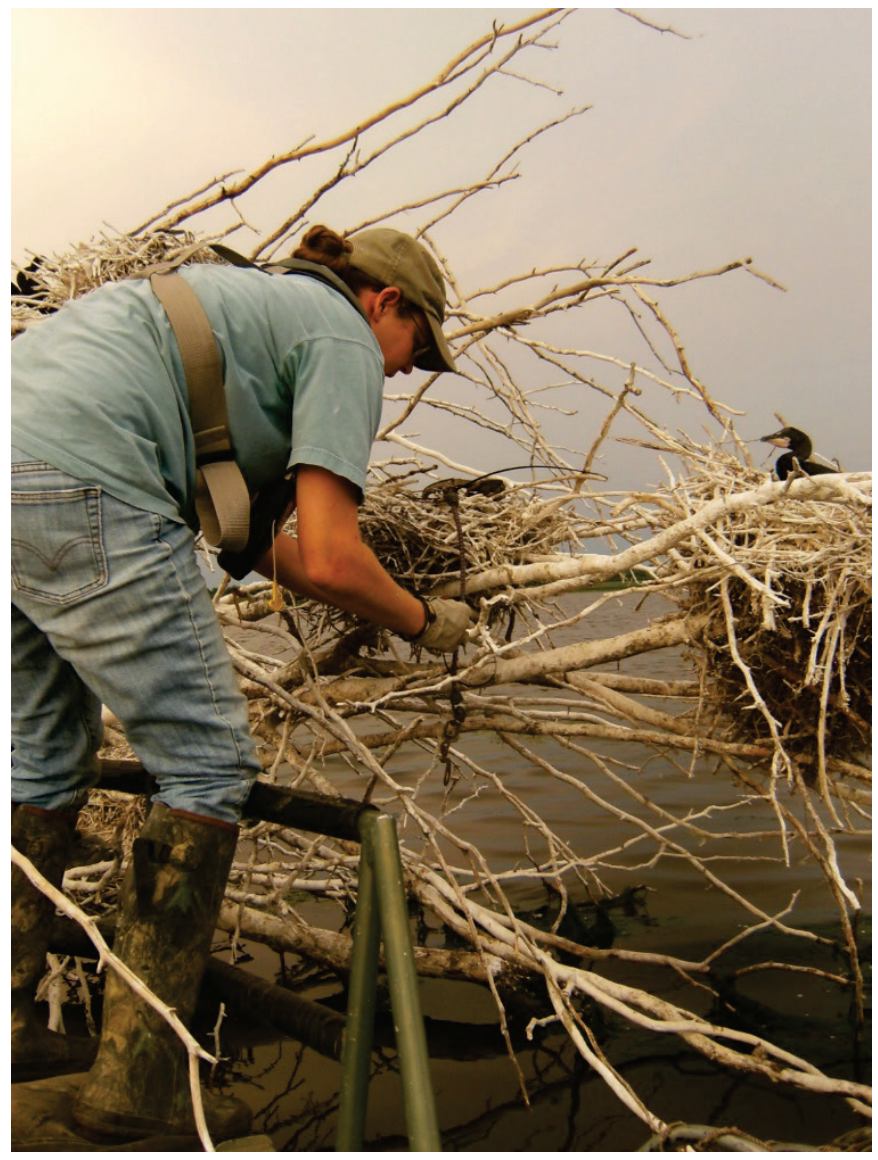


Figure 5. A USDA/WS/NWRC biologist records data at the processing station established on the shore of Baker's Lake, May 2012, during efforts to capture and tag Double-Crested Cormorants.

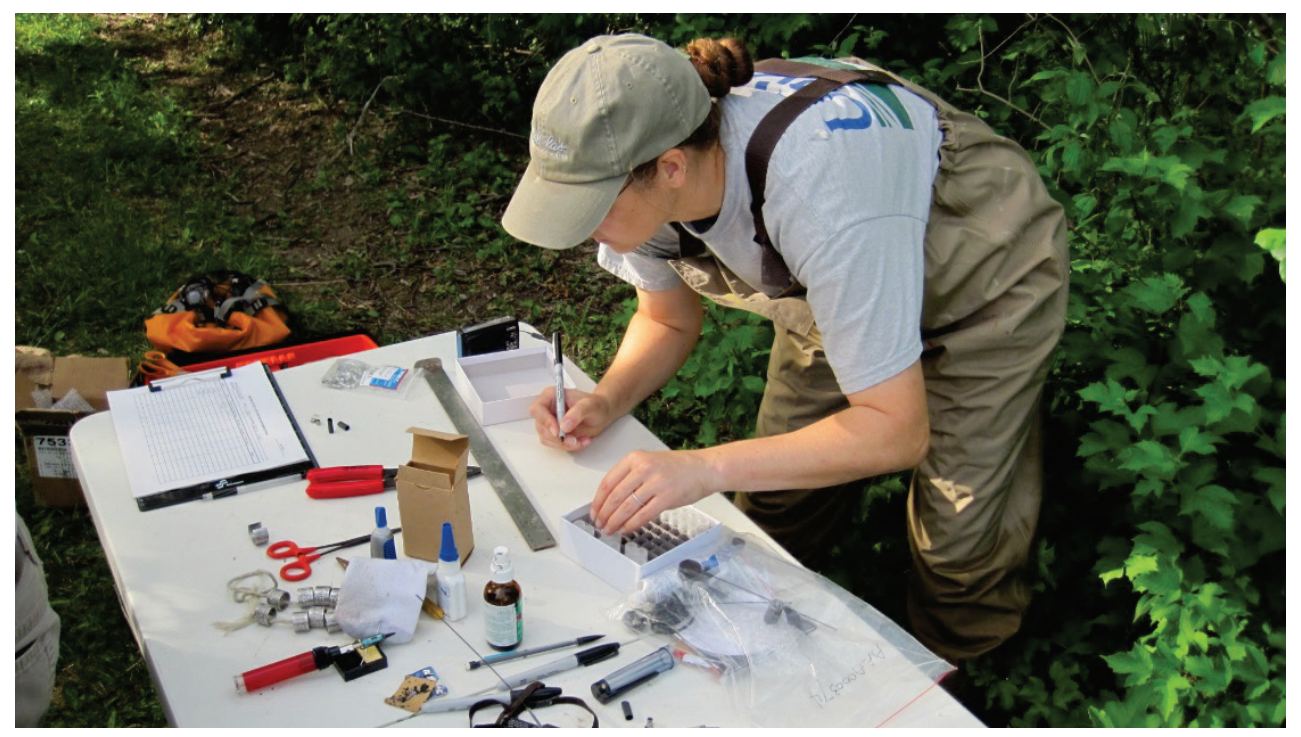

The team affixed all captured cormorants with Sirtrack® Argos Satellite Platform Transmitting Terminal (PTT) Harness Transmitters (model: $\mathrm{K}_{3} \mathrm{H}$ 174A KiwiSat 303) (Figure 6). These satellite tags use Doppler technology from orbiting satellites to estimate the location of transmitting tags on the Earth's surface. To maximize battery life, the satellite tags were programmed to transmit every other day for 14 hours. This permitted the team to observe early morning and late evening foraging movements for up to 6 months. The team used the data download capability available through CLS America, Inc. to regularly download all location data through an online website (CLS America, Inc. 2008). Downloaded data from Argos provided location error estimates provided in six location classes (LC): $\mathrm{LC}_{3}=<150 \mathrm{~m}, \mathrm{LC} 2=150$ to $<350 \mathrm{~m}, \mathrm{LC} 1=350$ to $\leq 1000 \mathrm{~m}, \mathrm{LCo}=>1000$, LCA and LCB- no estimate of location accuracy (CLS America, Inc. 2008). After the last satellite tag ended transmission (on December 24, 2012), all downloaded data were uploaded into ARCGIS 9.2 database for spatial analysis; data were then loaded into ARCGIS 10.1 for further analyses and presentation purposes. 
Figure 6. A Sirtrack Argos Satellite PPT transmitter is affixed to a Double-Crested Cormorant at the Baker's Lake colony site, May 2012.

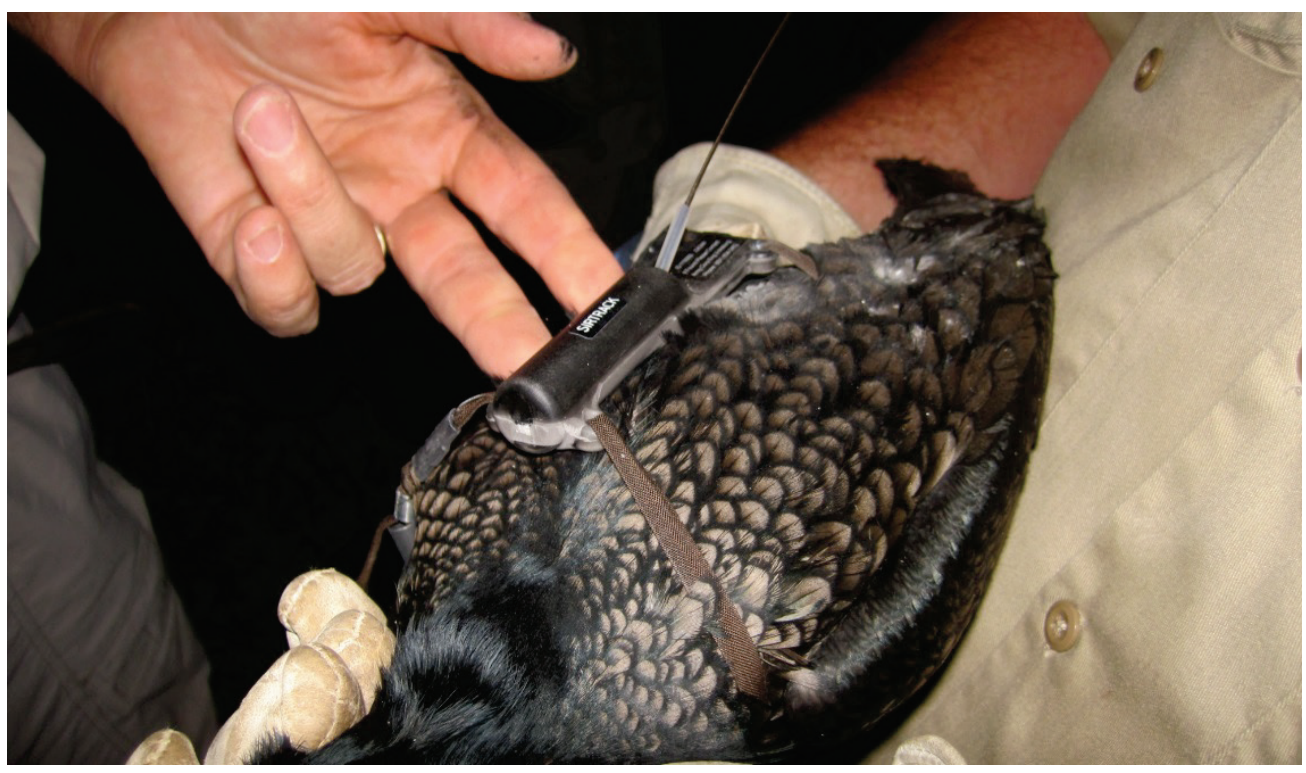

\section{Satellite Data Analyses}

All satellite transmissions were downloaded online weekly (http://argossystem.clsamerica.com/cwi/Logon.do) and maintained in a database using Microsoft Excel@, 2007. The team used the Argos Kalman Filtering algorithm option from CLS America, Inc., to increase the number and accuracy of locations. All location data were then loaded into ARCGIS 9.2 and 10.1 for analyses and presentation. After the last transmission (12-24-2012), these data were merged with data on daily movements (distance and bearing) (ARCGIS 9.2), and 50\% and 95\% kernel home-range-size data (ARCGIS 10.1) using SAS Enterprise Guide (2006-2010 SAS Institute, Inc.). The team performed kernel home ranges estimates for birds in each season having $\geq 50$ locations (Kernohan et al. 2001); thus, breeding season home ranges were constructed for 14 birds from Baker's Lake and 15 birds from TNC Emiquon Preserve; migration home ranges were constructed for 8 birds from each colony, and wintering home ranges were constructed for 4 birds from each colony. A biweight kernel estimation procedure (Laver 2005) was used to develop the 50\% and 95\% kernel home range estimates. This procedure provides a statistical approach to eliminating outliers, and is more similar to the adaptive-kernel estimator used by Kernohan et al. (2001); therefore, kernel home range may be larger than those presented by Dorr et al. (2012). The team used Hawth's Ecological Tools to examine movements, mean daily distance $(\mathrm{m})$, and direction of movements during 
the breeding (May 26 -July 12), migration (July 13 -October 31), and winter (November 1-December 24) seasons (Dorr et al. 2012).

Descriptive data, including the number of active transmitters per season, total and mean number of active days per colony, and total and mean number of satellite locations, were determined for each bird at each colony during each season. Mean total daily movements $(\mathrm{m})$ and bearing values (o$360^{\circ}$ ) based on satellite locations were statistically compared by season among both colonies using a T-Test procedure, and an ANOVA with Tukey's Multiple Range Tests were used to compare these metrics within each colony among the different seasons. Comparisons were made for seasonal mean 50\% and 95\% kernel home range size $\left(\mathrm{km}^{2}\right)$ for each tagged bird by colony and gender using a T-Test procedure. Comparison of mean daily movements, bearing, and 50\% and 95\% home range size among genders were also performed using a T-Test procedure. All statistical analyses were conducted using SAS Enterprise Guide (2006-2010 SAS Institute, Inc.).

\section{Results}

\section{Movements of Satellite Tagged Cormorants}

The team monitored movements of tagged Double-Crested Cormorants from the moment when tagged until the tag stopped transmitting. The battery life of transmitters was estimated at approximately 180 days or 6 months. Therefore, those tags that stopped transmitting in late October and later likely ended transmissions due to normal operating capabilities. Numerous tags ceased transmissions much earlier in the summer. Not all the diagnostic signals from those tags have been analyzed, but some tags likely failed due to bird mortality, tag malfunction, or harness failure. Some birds may have perished due to the record hot months of June and July in 2012. Cormorants also are notorious for behaviors that can cause significant damage to tags, including frequent plunge diving and scraping tags against rocks and other debris. Although the tags were largely waterproof, any seepage of water through the seals could have shortcircuited some tags, resulting in transmission failures.

For this study, the team was generally focused on cormorant behaviors and movements during the breeding season. Therefore, to address the question of whether cormorants may be acting as vectors of invasive carp eDNA, the team focused on those birds whose movement data are available at least until mid- July, although the authors provide movement 
results for all birds during the duration of the study (see Table 2). The requirement of these birds to meet both their nutritional needs and those of their young was thought to induce some birds (particularly, the birds in Baker's Lake) to travel distances sufficient to provide opportunities to forage on invasive carp. By returning back to the rookery, the birds would thereby be acting as vectors of carp eDNA through dissemination of carp tissues (e.g., while regurgitating food to young or by the excretion of fecal material throughout the CAWS).

The team recorded 24,030 satellite locations during the breeding (10,144 locations), migration (11,980 locations), and wintering (1,906 locations) seasons (Table 2). Eight birds tagged at TNC Emiquon Preserve and 8 birds tagged at Baker's Lake yielded movement data to mid-July or later; movements of all these birds are shown in Figures 7 - 9. During this study, birds exhibited a wide range of movements, with many taking long flights of hundreds - and even over a thousand - kilometers away from the capture/tagging location (Table 2; Figures 7 - 9).

During the breeding season, birds from TNC Emiquon Preserve and Baker's Lake tended to move in opposite directions (Figure 7). TNC Preserve birds moved northwest through Iowa and south to Missouri. Multiple birds spent time in the Davenport/Clinton, IA area (Figures 7 and 8), and 3 birds spent time near the Greenville/Greenwood, MS area (1 bird on the LA side of the river) (Figures 8 and 9). Several birds visited the Harry S. Truman Reservoir, MO, and Lake Eufaula, OK (Figures 8 and 9). Baker's Lake birds tended to move north, northeast, and east (Figure 7). Multiple birds tagged at Baker's Lake spent considerable time along the Lake Michigan coast, with several of these birds following the coast north to Green Bay, WI, and Chambers Island, WI; one bird spent a large portion of its time in Canada (Figures 7 and 8), while another bird moved east to Detroit, MI (Figure 8). Several birds from the TNC Emiquon Preserve wintered in the Mississippi Delta region of Mississippi and Louisiana, while birds from Baker's Lake wintered primarily along the Louisiana coast (Figure 9); two birds from Baker's Lake passed through Mobile, AL (Figures 8 and 9). One bird from the TNC site (Tag 119199) wintered along the Louisiana Coast very close to two birds from Baker's Lake (Tags 119195 and 119202; Table 2 and Figure 9). Figures (B1-B12) showing the $95 \%$ and $50 \%$ kernel home range extent for each tagged cormorant during each season at each site are available in Appendix B. Movement of all birds are described in Table 2. 
Table 2. Dates and number of observed locations (by season) and movements and fates of all Double-Crested Cormorants captured and fitted with Sirtrack $\circledast$ Argos Satellite PPT tags in 2012.

\begin{tabular}{|c|c|c|c|c|c|c|c|}
\hline \multirow[b]{2}{*}{ Rookery Site } & \multirow[b]{2}{*}{ Satellite Tag \# } & \multirow{2}{*}{$\begin{array}{c}\text { Last Transmission } \\
\text { Date }\end{array}$} & \multicolumn{3}{|c|}{ Number of Observed Locations } & \multirow[b]{2}{*}{ Total } & \multirow[b]{2}{*}{ Summary of Movements } \\
\hline & & & Breeding & Migration & Winter & & \\
\hline Baker's Lake & 119191 & $5 / 30 / 2012$ & 17 & 0 & 0 & 17 & $\begin{array}{l}\text { Transmission ended within } 48 \text { hours after tagged; never } \\
\text { left Baker's Lake area. }\end{array}$ \\
\hline Baker's Lake & 119193 & $6 / 7 / 2012$ & 121 & 0 & 0 & 121 & Movements $\leq 40 \mathrm{~km}$ around vicinity of Baker's Lake/CAWS. \\
\hline Baker's Lake & $119194^{*}$ & $12 / 12 / 2012$ & 483 & 1,119 & 200 & 1,802 & $\begin{array}{l}\text { Movement }>350 \mathrm{~km} \text { north along Lake Michigan coast to } \\
\text { Naubinway, Canada ( } 6 \text { weeks); post-breeding: south }>150 \mathrm{~m} \\
\text { to Manitowoc, WI; then south }>150 \mathrm{~km} \text { to Waukegan, IL } \\
\text { (CAWS area); then inland }>25 \mathrm{~km} \text { to Fox Lake ( } 6 \text { weeks); } \\
\text { fall/winter: south }>400 \mathrm{~km} \text { to Carlyle Reservoir, IL ( } 4 \text { weeks); } \\
\text { south }>70 \mathrm{~km} \text { to Rend Lake, IL ( } 4 \text { weeks), then south }>400 \\
\text { km to Tunica, MS ( } 1 \text { week); then south }>450 \mathrm{~km} \text { to Mobile, } \\
\text { AL. }\end{array}$ \\
\hline Baker's Lake & $119195^{*}$ & $12 / 6 / 2012$ & 424 & 972 & 176 & 1,572 & $\begin{array}{l}\text { Movements } 15-40 \mathrm{~km} \text { within Baker's Lake/CAWS area; post- } \\
\text { breeding: east }>400 \mathrm{~km} \text { to Detroit, MI, along Lake Erie coast } \\
\text { ( } 8 \text { weeks); fall/winter: another } 3 \text { weeks in Detroit, MI; then } \\
1,300 \mathrm{~km} \text { south to Mobile, AL; then }>80 \mathrm{~km} \text { west to Biloxi, } \\
\text { MS; then > } 220 \mathrm{~km} \text { west to coastal LA ( } 20 \text { mi. west of Theroit, } \\
\text { LA) (5 weeks). }\end{array}$ \\
\hline Baker's Lake & $119196^{*}$ & $9 / 7 / 2012$ & 472 & 584 & 0 & 1,056 & $\begin{array}{l}\text { Initial movements } \leq 50 \mathrm{~km} \text { between Baker's Lake and Lake } \\
\text { Forest along coast; then }>100 \mathrm{~km} \text { along Lake Michigan Coast } \\
\text { to Milwaukee, WI; north along coast }>100 \mathrm{~km} \text { to Manitowoc, } \\
\text { Wl; then north }>100 \text { to Chambers Island area, WI (near } \\
\text { Canada Border) for } 3 \text { weeks; post-breeding: movement }>85 \\
\text { km south to Green Bay, WI (4 weeks); then south back to } \\
\text { Busse Lake (within } 15 \mathrm{~km} \text { of Baker's Lake) in the CAWS. }\end{array}$ \\
\hline Baker's Lake & 119197 & $7 / 13 / 2012$ & 490 & 0 & 0 & 490 & $\begin{array}{l}\text { Movements } 25-100 \mathrm{~km} \text { in vicinity of Baker's Lake and } \\
\text { Waukegan, IL; along coast of Lake Michigan. }\end{array}$ \\
\hline Baker's Lake & 119200 & $6 / 25 / 2012$ & 317 & 0 & 0 & 317 & $\begin{array}{l}\text { Movements } 25-60 \mathrm{~km} \text { in vicinity of Baker's Lake and Lake } \\
\text { Forest, along coast of Lake Michigan. }\end{array}$ \\
\hline Baker's Lake & 119201 & $6 / 25 / 2012$ & 281 & 0 & 0 & 281 & $\begin{array}{l}\text { Movements } \geq 50 \mathrm{~km} \text { south to Yorkville and Plainfield, IL; last } \\
\text { location at Lake Renwick. }\end{array}$ \\
\hline
\end{tabular}




\begin{tabular}{|c|c|c|c|c|c|c|c|}
\hline \multirow[b]{2}{*}{ Rookery Site } & \multirow[b]{2}{*}{ Satellite Tag \# } & \multirow{2}{*}{$\begin{array}{c}\text { Last Transmission } \\
\text { Date }\end{array}$} & \multicolumn{3}{|c|}{ Number of Observed Locations } & \multirow[b]{2}{*}{ Total } & \multirow[b]{2}{*}{ Summary of Movements } \\
\hline & & & Breeding & Migration & Winter & & \\
\hline Baker's Lake & $119202^{*}$ & $12 / 10 / 2012$ & 466 & 1,048 & 297 & 1,811 & $\begin{array}{l}\text { Movement }>20 \mathrm{~km} \text { from Baker's Lake to Lake Forest along } \\
\text { the Lake Michigan coast; then north } 200 \mathrm{~km} \text { to Green Bay, } \\
\text { Wl; }>100 \mathrm{~km} \text { north to Chamber's Island, WI; return to Green } \\
\text { Bay ( } 5 \text { weeks): post-breeding: } 8 \text { weeks in Green Bay area; } \\
\text { fall/winter: } 4 \text { more weeks in Green Bay; then south }>1,100 \\
\text { km to West Helena, AR; then south }>220 \mathrm{~km} \text { to Tallulah, LA } \\
\text { ( } 2 \text { weeks); then }>300 \mathrm{~km} \text { south to coastal LA (around the } \\
\text { Vermilion and West Cote Blanche Bays) ( } 3 \text { weeks). }\end{array}$ \\
\hline Baker's Lake & $119206^{*}$ & $10 / 7 / 2012$ & 460 & 869 & 0 & 1,329 & $\begin{array}{l}\text { Movements between 10-60 km within the Baker's } \\
\text { Lake/CAWS area; post-breeding: movement about } 25-30 \mathrm{~km} \\
\text { south to Naperville, IL and Fox River ( } 8 \text { weeks); fall/winter: } \\
\text { movement > } 20 \mathrm{~km} \text { south to Plainfield, IL (around Lake } \\
\text { Renwick); another } 20 \mathrm{~km} \text { south of Joliet, IL, along Des Plaines } \\
\text { River. }\end{array}$ \\
\hline Baker's Lake & $119207^{*}$ & $8 / 4 / 2012$ & 455 & 236 & 0 & 691 & $\begin{array}{l}\text { Most movements } \leq 25 \mathrm{~km} \text { near Baker's Lake; divided time } \\
\text { between Baker's Lake, Deep Quarry Lake, and the Fox River } \\
\text { near Eglin, IL. }\end{array}$ \\
\hline Baker's Lake & 119208 & $6 / 29 / 2012$ & 344 & 0 & 0 & 344 & $\begin{array}{l}\text { Movements } \leq 25 \mathrm{~km} \text {; most time spent near Fish Lake about } \\
20 \mathrm{~km} \text { north of Baker's Lake. }\end{array}$ \\
\hline Baker's Lake & $119212^{*}$ & $7 / 29 / 2012$ & 503 & 169 & 0 & 672 & $\begin{array}{l}\text { Movements of } 25-60 \mathrm{~km} \text { north of Baker's Lake at Waukegan, } \\
\text { IL; along coast of Lake Michigan and inland at Fox Lake. } \\
\text { Satellite tag returned during spring 2013; found at Lake } \\
\text { Bogue Homa, near Laurel, MS. }\end{array}$ \\
\hline Baker's Lake & $119214^{*}$ & $12 / 4 / 2012$ & 219 & 594 & 135 & 948 & $\begin{array}{l}\text { Movements } \leq 25 \mathrm{~km} \text {; remained in and around the Baker's } \\
\text { Lake area for duration of study and all seasons. }\end{array}$ \\
\hline \multirow[t]{2}{*}{ Baker's Lake } & 119215 & $6 / 15 / 2012$ & 226 & 0 & 0 & 226 & $\begin{array}{l}\text { Large movements } \geq 100 \mathrm{~km} \text { north to Milwaukee, Wl, along } \\
\text { coast of Lake Michigan. }\end{array}$ \\
\hline & & Subtotal & 5,278 & 5,591 & 808 & 11,677 & \\
\hline TNC Emiquon & 119192 & $6 / 23 / 2012$ & 301 & 0 & 0 & 301 & Movements $\leq 20 \mathrm{~km}$ within vicinity of TNC site. \\
\hline TNC Emiquon & $119198^{*}$ & $9 / 17 / 2012$ & 454 & 644 & 0 & 1,098 & Movements $\leq 25 \mathrm{~km}$ within vicinity of TNC site. \\
\hline
\end{tabular}




\begin{tabular}{|c|c|c|c|c|c|c|c|}
\hline \multirow[b]{2}{*}{ Rookery Site } & \multirow[b]{2}{*}{ Satellite Tag \# } & \multirow{2}{*}{$\begin{array}{l}\text { Last Transmission } \\
\text { Date }\end{array}$} & \multicolumn{3}{|c|}{ Number of Observed Locations } & \multirow[b]{2}{*}{ Total } & \multirow[b]{2}{*}{ Summary of Movements } \\
\hline & & & Breeding & Migration & Winter & & \\
\hline TNC Emiquon & $119199^{*}$ & $12 / 24 / 2012$ & 462 & 1,137 & 393 & 1,992 & $\begin{array}{l}\text { Large movements } \geq 150 \mathrm{~km} \text { north through WI and MN; } \\
\text { remained in MN for breeding and post-breeding season ( } 6 \\
\text { weeks); fall migration/winter: large movements } \geq 200 \mathrm{~km} \\
\text { south to Cedar Rapids, MO; south to AR near Memphis, TN; } \\
\geq 200 \mathrm{~km} \text { south to LA just west of Greenville, MS; } \geq 200 \mathrm{~km} \text { to } \\
\text { coastal LA. }\end{array}$ \\
\hline TNC Emiquon & 119203 & $6 / 27 / 2012$ & 303 & 0 & 0 & 303 & Large movements $\geq 200$ km south IL, close to St. Louis, MO. \\
\hline TNC Emiquon & 119204 & $6 / 7 / 2012$ & 116 & 0 & 0 & 116 & Movement $>25$ to $\leq 80 \mathrm{~km}$; remained in vicinity of TNC site. \\
\hline TNC Emiquon & 119205 & $6 / 5 / 2012$ & 111 & 0 & 0 & 111 & Movements $\leq 25 \mathrm{~km}$; remained in vicinity of TNC site. \\
\hline TNC Emiquon & $119209^{*}$ & $11 / 8 / 2012$ & 427 & 936 & 0 & 1,363 & $\begin{array}{l}\text { Large movements } \leq 200 \mathrm{~km} \text { north to Davenport/Clinton, IA; } \\
\text { then south } \leq 600 \mathrm{~km} \text { to Lake Eufaula, OK; post-breeding: } \leq 25 \\
\text { km movements in vicinity of Lake Eufaula; fall/winter: } \\
\text { movements } 25-75 \mathrm{~km} \text { in vicinity of Lake Eufaula. }\end{array}$ \\
\hline TNC Emiquon & 119210 & $7 / 21 / 2012$ & 424 & 108 & 0 & 532 & $\begin{array}{l}\text { Large movements } \leq 200 \mathrm{~km} \text { west to } \mathrm{MO} \text {; then } 5 \text { weeks at } \\
\text { Harry S. Truman Reservoir, MO. }\end{array}$ \\
\hline TNC Emiquon & 119211 & $6 / 25 / 2012$ & 309 & 0 & 0 & 309 & Movements $\leq 25 \mathrm{~km}$ in vicinity of TNC site. \\
\hline TNC Emiquon & $119213^{*}$ & $12 / 14 / 2012$ & 482 & 1050 & 304 & 1,836 & $\begin{array}{l}\text { Movements } \geq 150 \mathrm{~km} \text { north to Davenport/Clinton, IA; then } \\
\text { southwest to MO; west beyond Kansas City, MO; southeast to } \\
\text { Harry S. Truman, MO; return back to TNC site; post-breeding: } \\
\text { remained in vicinity of TNC site; fall/winter: large movement } \\
\geq 500 \mathrm{~km} \text { south to Greenville/Greenwood, MS - remained for } \\
8 \text { weeks. }\end{array}$ \\
\hline TNC Emiquon & $119216^{*}$ & $12 / 4 / 2012$ & 419 & 953 & 139 & 1,511 & $\begin{array}{l}\text { Movements between } 25-50 \mathrm{~km} \text { in vicinity of TNC site for } \\
\text { breeding/post-breeding; fall/winter: large movements } \geq 300 \\
\text { km southwest to Harry S. Truman Reservoir, MO ( } 4 \text { weeks); } \\
\geq 200 \mathrm{~km} \text { to Great Lake O' the Cherokees, OK; }>200 \mathrm{~km} \\
\text { south to Robert S. Kerr Reservoir, OK, then } \geq 350 \mathrm{~km} \text { to } \\
\text { Dallas, TX. }\end{array}$ \\
\hline TNC Emiquon & $119217^{*}$ & $12 / 12 / 2012$ & 430 & 992 & 262 & 1,684 & $\begin{array}{l}\text { Large movements }>300 \mathrm{~km} \text { south to central LA and } \\
\text { Greenville/Greenwood MS area; post-breeding-fall/winter: } \\
\text { movements } 25-60 \mathrm{~km} \text {, remains around } \\
\text { Greenville/Greenwood, MS (about } 10 \text { weeks). }\end{array}$ \\
\hline TNC Emiquon & 119218 & $6 / 7 / 2012$ & 96 & 0 & 0 & 96 & Movements $\leq 15 \mathrm{~km}$ in vicinity of TNC site. \\
\hline
\end{tabular}




\begin{tabular}{|c|c|c|c|c|c|c|c|}
\hline \multirow[b]{2}{*}{ Rookery Site } & \multirow[b]{2}{*}{ Satellite Tag \# } & \multirow{2}{*}{$\begin{array}{l}\text { Last Transmission } \\
\text { Date }\end{array}$} & \multicolumn{3}{|c|}{ Number of Observed Locations } & \multirow[b]{2}{*}{ Total } & \multirow[b]{2}{*}{ Summary of Movements } \\
\hline & & & Breeding & Migration & Winter & & \\
\hline TNC Emiquon & 119219 & $6 / 5 / 2012$ & 120 & 0 & 0 & 121 & Movements $\leq 25 \mathrm{~km}$ in vicinity of TNC site. \\
\hline \multirow[t]{3}{*}{ TNC Emiquon } & $119220^{*}$ & 9/7/2012 & 412 & 569 & 0 & 981 & $\begin{array}{l}\text { Large movements } \geq 100 \mathrm{~km} \text { to Davenport/Clinton, IA, return } \\
\text { to TNC site; return to Davenport, IA for } 3 \text { weeks; back to TNC } \\
\text { site; post-breeding: movement } \geq 250 \mathrm{~km} \text { to St. Louis, MO; to } \\
\text { Memphis, TN and North, MS; returned north near Dyersburg, } \\
\text { TN. }\end{array}$ \\
\hline & & Subtotal & 4,866 & 6,389 & 1,098 & 12,353 & \\
\hline & & Total & 10,144 & 11,980 & 1,906 & 24,030 & \\
\hline
\end{tabular}

*Birds with sufficient transmitter duration (till July 11, 2012) plus number of locations to permit future analyses on movement frequency, average distance, and habitat use during the breeding season. 
Figure 7. Breeding home range polygons of Double-Crested Cormorant movements from Baker's Lake (blue outline) and the TNC Emiquon Preserve (red outline), May 26

- July 12, 2012.

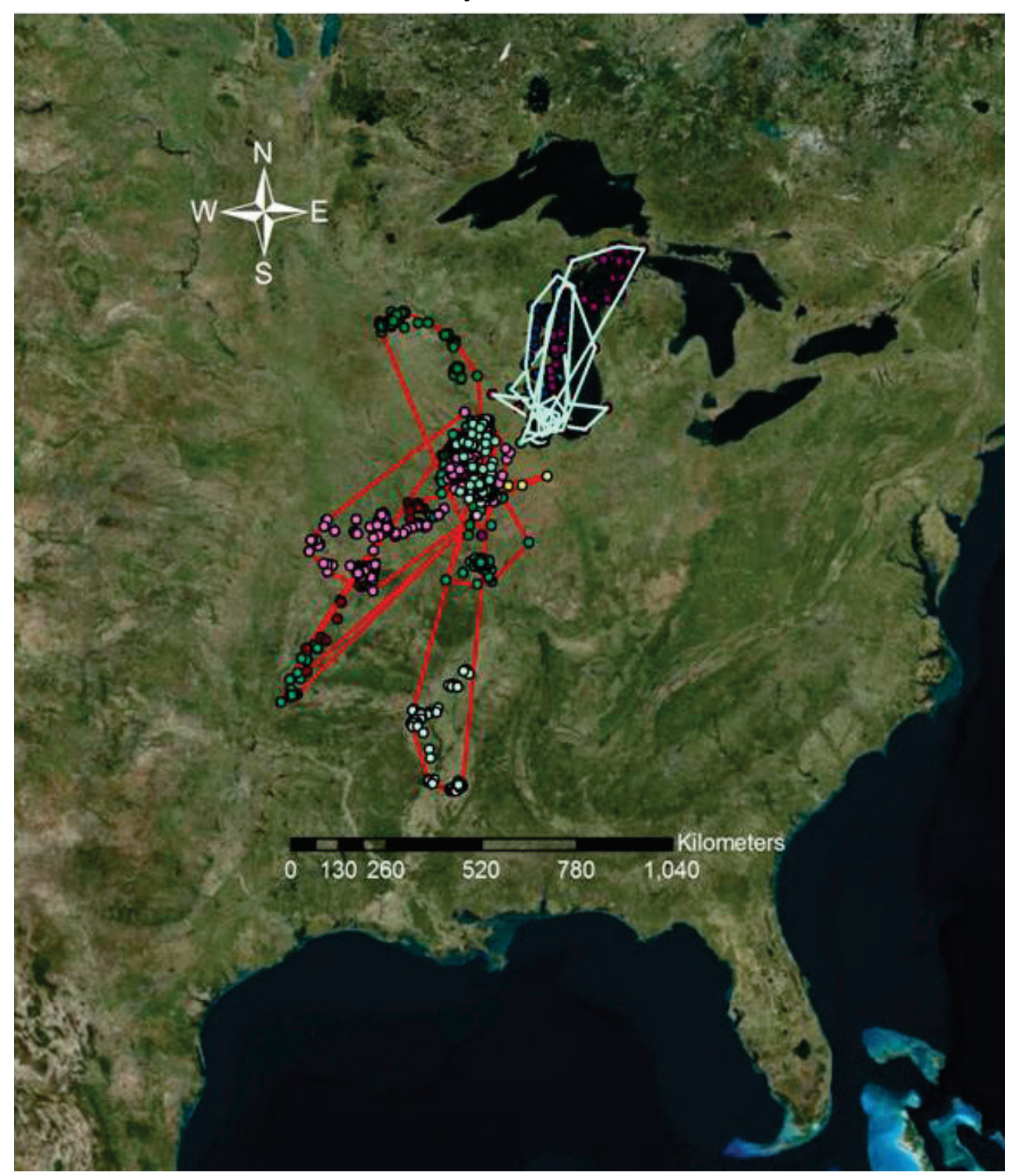


Figure 8. Migration home range polygons of Double-Crested Cormorant movements from Baker's Lake (blue outline) and the TNC Emiquon Preserve (red outline), July 13 - October 31, 2012.

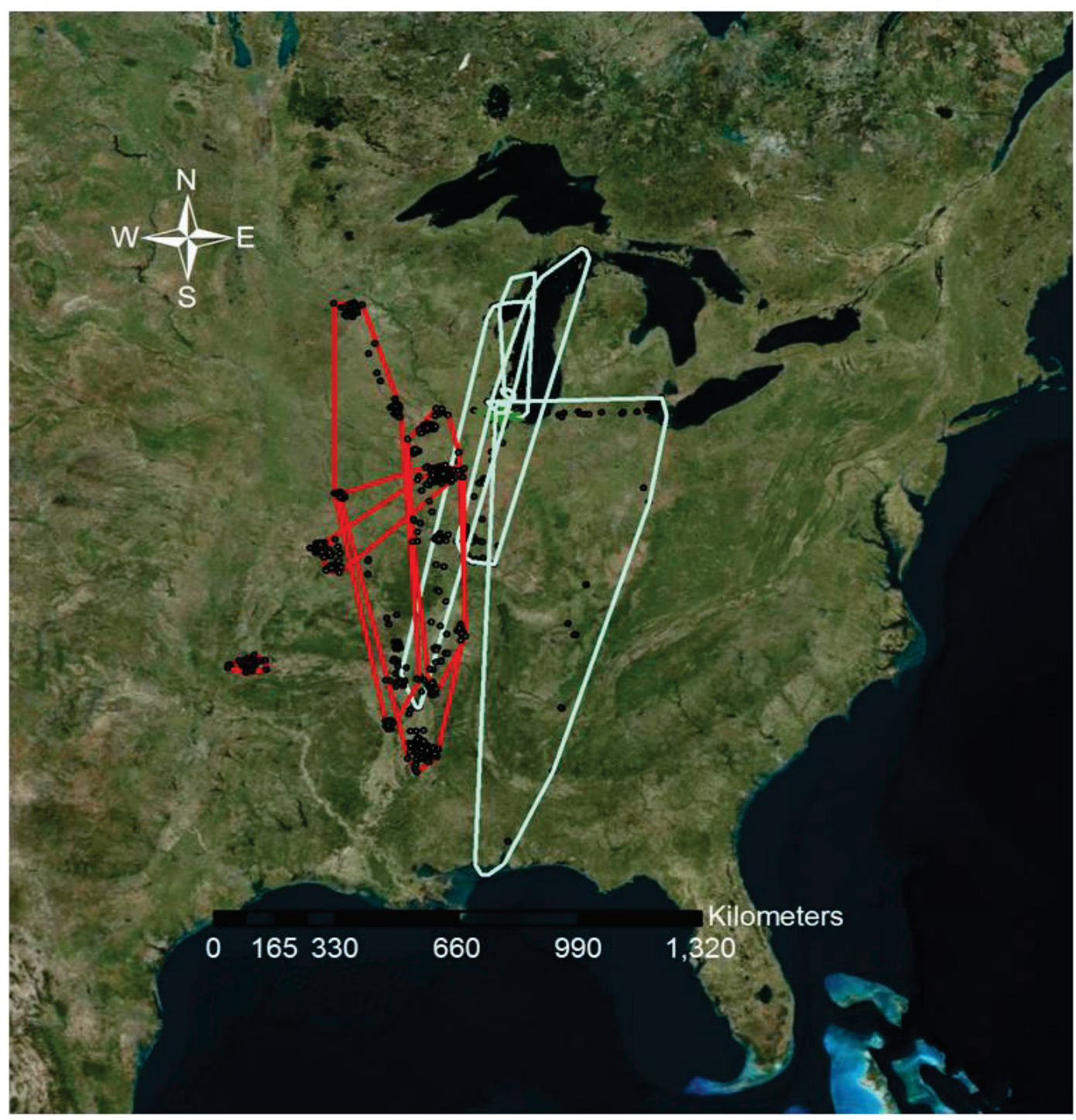


Figure 9. Wintering home range polygons of Double-Crested Cormorant movements from Baker's Lake (blue outline) and TNC Emiquon Preserve (red outline), November 1 - December $24,2012$.

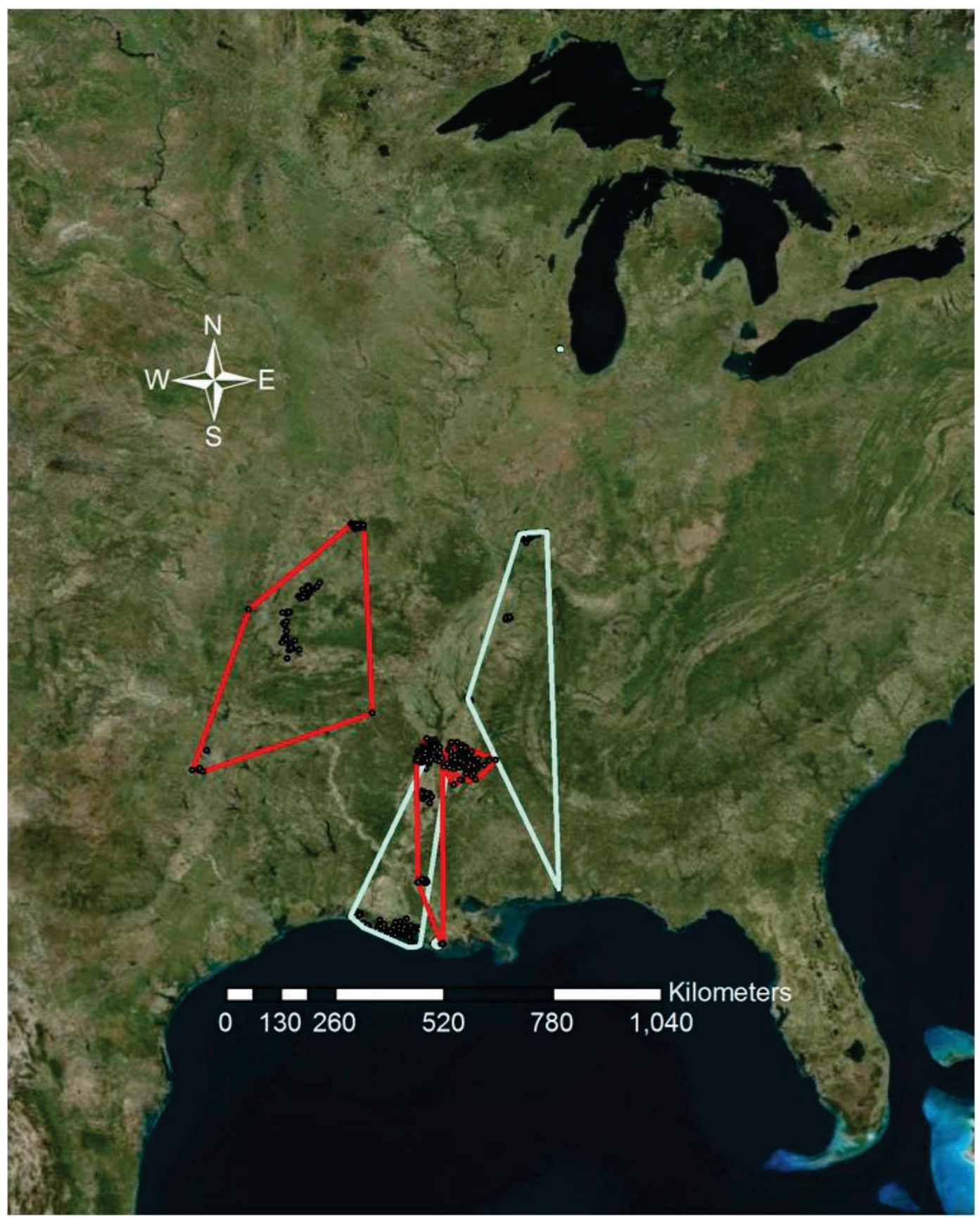

\section{Daily Movements, Bearing, and Home Range Results}

Cormorants from Baker's Lake and TNC Preserve exhibited similar patterns. Fourteen cormorants from Baker's Lake, and 15 cormorants from TNC Preserve maintained active transmitters during the breeding season; 8 birds from each site were active and transmitting during the migration 
season, while 4 birds for each site were active during the wintering season (Table 3). The number and mean of active days, and the number and mean of total locations per site were very similar for both colonies (Table 3). Birds from Baker's Lake moved significantly farther distances during the breeding season than during the migration and wintering seasons; while TNC Preserve birds moved significantly more during the winter than both breeding and migration seasons; mean breeding season movements were farther than migration movements (Table 3). No differences were observed in mean distance of birds at each colony during the breeding and migration seasons, but TNC Preserve birds moved farther than Baker's Lake birds during the wintering season (Table 3). No seasonal differences were observed for bearing either among the seasons or between colonies (Table 4). Also, likely due to small sample sizes and high variation, no significant differences were observed among 50\% and 95\% mean kernel home range size $\left(\mathrm{km}^{2}\right)$ or perimeter length $(\mathrm{km})$ estimates among the colonies during any season (Table 5).

Table 3. Number of cormorants, total and mean active days, and total and mean number of satellite locations recorded by 30 tagged cormorants from Baker's Lake, Barrington, IL, and TNC Emiquon Preserve, near Havana, IL, 2012.

\begin{tabular}{|l|c|c|c|c|c|}
\hline Colony & $\begin{array}{c}\text { No. } \\
\text { Cormorants }\end{array}$ & $\begin{array}{c}\text { Total No. } \\
\text { Active } \\
\text { Days }\end{array}$ & $\begin{array}{c}\text { Mean No. } \\
\text { Active Days } \\
\text { (SE) }\end{array}$ & $\begin{array}{c}\text { Total No. } \\
\text { Locations }\end{array}$ & $\begin{array}{c}\text { Mean No. } \\
\text { Locations (SE) }\end{array}$ \\
\hline Baker's Lake & & & & & \\
\hline Breeding & 14 & 279 & $19.93(1.52)$ & 5,261 & $375.79(33.08)$ \\
\hline Migration & 8 & 314 & $22.43(6.65)$ & 5,591 & $698.88(128.25)$ \\
\hline Wintering & 4 & 76 & $5.43(2.93)$ & 808 & $202.0(34.39)$ \\
\hline TOTAL & 14 & 669 & $47.79(9.76)$ & 11,660 & $448.46(54.82)$ \\
\hline TNC Preserve & & & & & \\
\hline Breeding & 15 & 259 & $17.27(1.90)$ & 4,866 & $324.40(37.35)$ \\
\hline Migration & 8 & 343 & $22.87(6.66)$ & 6,389 & $798.63(120.37)$ \\
\hline Wintering & 4 & 87 & $5.80(2.61)$ & 1,098 & $274.50(52.78)$ \\
\hline TOTAL & 15 & 689 & $45.93(10.31)$ & 12,353 & $457.52(59.30)$ \\
\hline
\end{tabular}


Table 4. Comparison of mean step distance $(\mathrm{m})$ and bearing of cormorants among seasons within each colony (ANOVA and Tukey's Multiple Range Test) ${ }^{1}$, and comparison of step distance and bearing between colonies (T-Test) ${ }^{2}$.

\begin{tabular}{|l|c|c|c|}
\hline Colony & $\begin{array}{c}\text { No. } \\
\text { Locations }\end{array}$ & Mean Step Distance $(\mathrm{m})(\mathrm{SE})$ & Mean Bearing (SE) \\
\hline Baker's Lake & & & \\
\hline Breeding & 4,988 & $6,686.20(149.60)^{\mathrm{a}^{* * *}}$ & $178.60(1.45)$ \\
\hline Migration & 5,277 & $5,235.49(144.88)^{\mathrm{b}}$ & $175.47(1.42)$ \\
\hline Wintering & 733 & $4,654.33(234.28)^{\mathrm{b}}$ & $182.51(3.72)$ \\
\hline TNC Preserve & & & \\
\hline Breeding & 4,633 & $6,575.60(170.60)^{b^{* * *}}$ & $179.86(1.50)$ \\
\hline Migration & 6,046 & $5,075.48(103.09)^{\mathrm{c}^{* * *}}$ & $177.56(1.31)$ \\
\hline Wintering & 1,011 & $8,182.94(559.79)^{a^{* * *} \dagger}$ & $181.28(3.20)$ \\
\hline
\end{tabular}

${ }^{1}$ Different letters denote significant differences among season; ${ }^{*}<0.05,{ }^{* *}<0.001,{ }^{* * *}<0.001$.

2Significant difference of higher mean value; $\uparrow<0.05$.

Table 5. Comparison ${ }^{1}$ of seasonal $95 \%$ and $50 \%$ mean kernel home range size $\left(\mathrm{km}^{2}\right)$ and perimeter length $(\mathrm{km})$ among cormorants from Baker's Lake and TNC Preserve.

\begin{tabular}{|l|c|c|c|c|c|}
\hline Colony & $\mathrm{n}$ & $\begin{array}{c}\text { Mean Size }\left(\mathrm{km}^{2}\right) \\
95 \% \text { Kernel HR (SE) }\end{array}$ & $\begin{array}{c}\text { Mean 95\% } \\
\text { Perimeter length } \\
(\mathrm{km})(\mathrm{SE})\end{array}$ & $\begin{array}{c}\text { Mean Size }\left(\mathrm{km}{ }^{2}\right) \\
50 \% \text { Kernel HR } \\
(\mathrm{SE})\end{array}$ & $\begin{array}{c}\text { Mean } 50 \% \\
\text { Perimeter } \\
\text { Length (km) (SE) }\end{array}$ \\
\hline Baker's Lake & & & & & \\
\hline Breeding & 14 & $4,928.55(2,341.47)$ & $443.50(110.30)$ & $596.45(274.88)$ & $108.50(30.17)$ \\
\hline Migration & 8 & $8,653.92(5,002.92)$ & $185,259(184,728)$ & $\begin{array}{c}1,459.44 \\
(880.90)\end{array}$ & $188.10(66.52)$ \\
\hline Wintering & 4 & $9,187.77(7,411.37)$ & $440.80(257.50)$ & $\begin{array}{c}1,963.94 \\
(1,740.59)\end{array}$ & $\begin{array}{c}196.80 \\
(152.40)\end{array}$ \\
\hline TNC Preserve & & & & $\begin{array}{c}2,979.03 \\
(1,109.49)\end{array}$ & $208.60(68.89)$ \\
\hline Breeding & 15 & $19,054.35(7,061.22)$ & $785.30(239.40)$ & $\begin{array}{c}1,225.79 \\
(526.58)\end{array}$ & $134.10(48.57)$ \\
\hline Migration & 8 & $13,372.93(5,876.19)$ & $806.40(321.90)$ & $\begin{array}{c}2,956.22 \\
(3,125.51)\end{array}$ & $254.10(144.3)$ \\
\hline Wintering & 4 & $13,666.14(11,106.17)$ & $652.90(271.30)$ & & \\
\hline
\end{tabular}

1T-Test between colonies by season; no significant differences observed.

During the breeding and migration seasons, females moved significantly farther than males from both colonies, while no difference was observed during the wintering season (Table 6). No differences in bearing of movements by the sexes were observed during any season (Table 6). During the breeding season, males had larger mean home range sizes than females, yet 
the only statistical difference was observed during the breeding season for the 50\% home range polygons (Table 7). During the migration and wintering seasons, females tended to have larger home ranges, but results were not statistically different (Table 7). No statistical differences in home range perimeter length were observed among the sexes during any season (Table 7). As with prior analyses, results may be affected by low sample sizes and high individual variation among the birds.

Table 6. Comparison ${ }^{1}$ of mean step distance $(\mathrm{m})$ and bearing among sexes by season for cormorants the Baker's Lake and TNC Emiquon Preserve.

\begin{tabular}{|l|c|c|c|c|c|}
\hline \multirow{2}{*}{ Season } & Sex & No. Birds & No. Locations & $\begin{array}{c}\text { Mean Step Distance } \\
(\mathrm{m})(\mathrm{SE})\end{array}$ & $\begin{array}{c}\text { Mean Bearing } \\
(\mathrm{SE})\end{array}$ \\
\hline \multirow{3}{*}{ Breeding } & $\mathrm{F}$ & 14 & 4,429 & $7,227.80(175.20)^{\dagger}$ & $178.70(1.54)$ \\
\cline { 2 - 6 } & $\mathrm{M}$ & 15 & 5,192 & $6,125.50(146.20)$ & $179.70(1.41)$ \\
\hline \multirow{3}{*}{ Migration } & $\mathrm{F}$ & 7 & 5,414 & $5,498.30(121.70)^{\dagger}$ & $175.60(1.40)$ \\
\cline { 2 - 7 } & $\mathrm{M}$ & 9 & 5,909 & $4,830.90(124.10)$ & $177.5(1.33)$ \\
\hline \multirow{2}{*}{ Wintering } & $\mathrm{F}$ & 4 & 694 & $6,704.40(744.50)$ & $184.30(3.77)$ \\
\cline { 2 - 7 } & $\mathrm{M}$ & 4 & 1,050 & $6,696.90(282.9)$ & $180.10(3.16)$ \\
\hline
\end{tabular}

1T-Test: significant difference of higher mean value; $\dagger<0.05$.

Table 7. Comparison ${ }^{1}$ of mean $95 \%$ and $50 \%$ mean kernel home range size $\left(\mathrm{km}^{2}\right)$ and perimeter length $(\mathrm{km})$ among sexes for cormorants from the Baker's Lake and TNC Emiquon Preserve.

\begin{tabular}{|l|c|c|c|c|c|c|}
\hline \multirow{3}{*}{ Season } & Sex & $\begin{array}{c}\text { No. } \\
\text { Birds }\end{array}$ & $\begin{array}{c}\text { Mean Size }\left(\mathrm{km}^{2}\right) \text { 95\% } \\
\text { Kernel HR (SE) }\end{array}$ & $\begin{array}{c}\text { Mean 95\% } \\
\text { Perimeter length } \\
(\mathrm{km})(\mathrm{SE})\end{array}$ & $\begin{array}{c}\text { Mean } 50 \% \\
\text { Kernel HR (SE) }\end{array}$ & $\begin{array}{c}\text { Perimeter } \\
\text { Length } \\
(\mathrm{km})(\mathrm{SE})\end{array}$ \\
\hline Breeding & $\mathrm{F}$ & 14 & $4,882.82(2,378.06)$ & $410.20(118.30)$ & $559.40(275.84)$ & $88.99(27.31)$ \\
\cline { 2 - 7 } & $\mathrm{M}$ & 15 & $19,097.03(7,044.48)$ & $816.50(232.30)$ & $3,013.61(1,103.89) \dagger$ & $266.70(67.67)$ \\
\hline Migration & $\mathrm{F}$ & 7 & $12,134.04(6,331.69)$ & $211,891(211.077)$ & $1,669.80(989.68)$ & $170.80(74.94)$ \\
\cline { 2 - 8 } & $\mathrm{M}$ & 9 & $10,141.85(4,894.65)$ & $587.90(240.60)$ & $1,088.15(482.07)$ & $120.60(42.31)$ \\
\hline \multirow{2}{*}{ Wintering } & $\mathrm{F}$ & 4 & $20,895.37(10,986.19)$ & $788.80(311.70)$ & $4,645.93(2,592.85)$ & $363.80(174.0)$ \\
\cline { 2 - 7 } & $\mathrm{M}$ & 4 & $1,958.54(1,074.44)$ & $304.90(105.90)$ & $274.63(159.64)$ & $87.10(39.55)$ \\
\hline
\end{tabular}

${ }^{1 T}$-Test between seasons by sex; significant difference of higher mean value; $\dagger<0.05$.

\section{Discussion}

The Double-Crested Cormorant is an abundant and wide-spread piscivorous bird that is well known for aggressive predation on lake and riverine fish (Dorr et al. 2014, Wires and Cuthbert 2006). Over the past 
40 years, the population of this species has increased and expanded rapidly throughout North America and Canada, causing conflicts due to perceived or actual impacts on sport fisheries and aquaculture (Nettleship and Duffy 1995, Tobin 1999, Wires and Cuthbert 2006, Dorr and Somers 2012). Cormorants are known to be voracious but opportunistic predators on a variety of fish species; prey diversity is usually dependent upon availability (Dorr et al. 2010a, 2010b, Dorr et al. 2014, Ridgway 2010, Andrews et al. 2012). Moreover, cormorants are well-known for making variable, yet frequent long-distance movements $(>30 \mathrm{~km})$ while foraging (Dorr et al. 2012, Dorr et al. 2014, King et al. 2012a,b). The combination of high cormorant abundance in the central Illinois-Great Lakes region, aggressive predatory behavior on fish, and tendency to embark on longdistance flights, led the group to hypothesize that cormorants may potentially be an avian vector of invasive carp eDNA in the CAWS.

First, the team used eBird observational data to document that the DoubleCrested Cormorant is the most abundant piscivorous bird in the Chicago metropolitan area during the breeding season (see Chapter 1, Table 1). Second, the team verified that cormorants from both colonies were foraging on invasive carp from the results of the DNA analyses performed on the throat and cloacal swabs (Guilfoyle et al. 2017). Finally, based on the satellite-derived movements, the team determined that the cormorants do indeed make long-distance flights (mean flight step distance $>65 \mathrm{~km}$ for cormorants from both colonies during the breeding season; see Table 4). Such flights are necessary from the birds in the Baker's Lake colony that are approximately $115^{+} \mathrm{km}$ from carp-spawning areas north of Peoria, IL (USFWS 2015) ${ }^{1}$, and approximately $56 \mathrm{~km}$ north of the EDB. These data support the idea that cormorants, and perhaps other piscivorous birds in the central Illinois-Great Lakes Region, are capable of being invasive carp DNA vectors throughout the CAWS. However, it should be noted that the tagged birds from Baker's Lake did not make noticeable flights to and from areas with known carp populations. In fact, the breeding cormorants from Baker's Lake and the TNC Emiquon Preserve colonies had distinctly different and non-overlapping movements and home ranges (see Figure 7). Based on the throat/cloacal swab results, cormorants from Baker's Lake were feeding on invasive carp, but movement data from the satellite tags do not provide a clear picture of where the birds may be foraging on carp. The only area with overlapping home ranges of some breeding cormorants from

\footnotetext{
1 Baerwaldt, K. L., A. Benson, and K. Irons. 2013. Asian carp distribution in North America. Unpublished
} report, U.S. Army Corps of Engineers, Chicago District. 
Baker's Lake and known distribution of carp is within the area below the EDB near Lockport, $\mathrm{IL}^{1}$; however, these data do not explain where all the cormorants may be foraging on carp.

The results have been supported and augmented by additional research from the USACE ECALS effort (ACRCC 2013, 2014, Merkes el al. 2014). Results from caged Bald Eagles, American White Pelicans, White Ibises (Eudocimus albus), and Double-Crested Cormorants indicate that birds fed a meal of invasive carp will still have detectable invasive carp DNA in their feces for up to 7 days later (ACRCC 2013, Merkes et al. 2014).

Standing water samples from the captive bird habitat also show that birds could contaminate a ponded water source with invasive carp eDNA, likely through feces discharge (ACRCC 2013). Bird feces deposited on sterile cooking sheets (to simulate barge or boat surfaces) and fully exposed to the elements revealed detectable traces of invasive carp eDNA for up to 28 days (ACRCC 2013, Merkes et al. 2014). In addition, it is possible that invasive carp DNA can bind with organic molecules, forming recalcitrant DNA that may persist in the aquatic environment for up to 90 days (Dejean et al. 2011, ACRCC 2014). These results are particularly pertinent to cormorants that can form large colonies in the CAWS (see Figure 3 above). Continuous foraging on carp, plus the repeated excretions of fecal material on the large artificial nesting structure on Baker's Lake and elsewhere (e.g., Lake Renwick, in Romeoville, IL), likely provide a source of carp DNA contamination of surrounding water bodies for many days after initial carp consumption and defecation by the cormorants. With every rain event, carp DNA is likely flushed from such structures and into the water system (Klimaszyk et al. 2008, 2014). Moreover, a nutrient loading model for Double-Crested Cormorants was developed by Guilfoyle and Schultz ${ }^{2}$ and indicates that tens of millions to billions copies of invasive carp DNA could be deposited daily by cormorants into the CAWS. While this study cannot assess the relative contribution of carp DNA into the CAWS by cormorants or other piscivorous birds from other potential vector sources (e.g., boat hulls, bilge pumps, etc.) (ACRCC 2013, Schultz et al. 2014), the team's data suggest that it is likely that piscivorous birds,

\footnotetext{
1 Baerwaldt, K. L., A. Benson, and K. Irons. 2013. Asian carp distribution in North America. Unpublished report, U.S. Army Corps of Engineers, Chicago District.

2 Guilfoyle, M. P., and M. T. Schultz. (In review). The contribution of double-crested cormorants (Phalacrocorax auritus) to silver carp (Hypophthalmichthys molitrix) DNA loads in the Chicago Area Waterway System. The Journal of Great Lakes Research.
} 
particularly the Double-Crested Cormorant, are important vectors of invasive carp eDNA in the CAWS.

\section{Other Seasonal and Demographic Information about Cormorants}

Seasonal movement data and specific demographic differences within cormorant populations remain understudied (Dorr and Somers 2012). Therefore, the team took the opportunity to learn more about seasonal movements of Double-Crested Cormorants. In addition, using collected feather samples, the team used genetic sexing analyses to determine the sex of all captured cormorants (Guilfoyle et al. 2017). This permitted the team to examine seasonal differences among the genders for daily movement patterns, average bearing, home range sizes, and home range perimeter lengths. Comparing results from Baker's Lake and TNC Emiquon Preserve also permitted the team to examine any potential differences among birds from an urban (Baker's Lake) and rural (TNC Preserve) colony.

The 95\% and 50\% kernel home ranges estimated presented in this report are very large (See Appendix B); much larger than those reported by other researchers (Scherr et al. 2010, Guillaumet et al. 2011, Dorr et al.2012), and more in line with home ranges presented by King et al. (2012a,b). This result is likely due to the relatively small number of birds used for the home range analyses (especially for the migration and wintering seasons) and the use of a biweight kernel estimator (Laver 2005), which is more similar to the adaptive-kernel estimator used by King et al. (2012a,b) than the fixed-kernel estimator used by Dorr et al. (2012).

The team's marked birds generally had larger winter home ranges than summer home ranges, similar to results of Scherr et al. (2010) and differing from results of King et al. (2012a). The team found birds from Baker's Lake having nearly double winter home range sizes than summer home ranges, while birds from the TNC Preserve had slightly larger winter home ranges than during the summer. These results may be due to differences in sample sizes between the seasons or capture and handling effects on birds marked during the winter by King et al. (2012a). Also, one bird from Baker's Lake had remarkably small home ranges during each season, rarely venturing more than $10 \mathrm{~km}$ per movement, and rarely moving beyond the original capture location (even during the winter season) and may constitute an outlier affecting the results. The smaller seasonal home ranges in general by birds from Baker's Lake (especially during the summer), may be due in part 
because of the relatively large number of stocked ponds in and around the CAWS, producing a result similar to King et al. (2012a) of birds around aquaculture-intensive areas. While several birds captured at Baker's Lake moved great distances into Canada or Green Bay, WI (and one bird moved to Detroit, MI) (see Figures B1-B12) during the breeding and migration seasons, these birds tended to remain largely in urbanized areas that also were likely to possess numerous stocked ponds. Regardless, individual cormorants show substantial individual variation in movements. Further ongoing analyses on habitat utilization by these birds may provide more insight into this phenomenon. Birds from both colonies tended to winter in the Mississippi Alluvial Valley (MAV) and coastal Louisiana, with one bird from the TNC Emiquon Preserve wintering westward into OK and northern TX. These results further support results by Guillaumet et al. (2011) and Dorr et al. (2012) that birds along the western Great Lakes (which include birds from both colonies in this study) tend to migrate and winter using the Mississippi Flyway.

King et al. (2012b) looked at spring migration from the MAV to northern breeding grounds. In this study, the team looked at fall migration from the northern breeding grounds to wintering areas in the MAV and coastal LA. Many of the birds tagged by King et al. (2012b) followed similar migration routes to breeding areas in and around the Chicago area, and north along Lake Michigan to MN, Green Bay, WI, and into Canada; very close to where several of the birds spent a significant amount of time during the breeding and migration seasons. A few birds from King et al. (2012b) even flew to Detroit, MI, like one of the birds in this study. If the team had used satellite tags designed to last longer, it is likely that these birds would have moved north in a similar pattern during fall migration. Numerous cormorants tagged by King et al. (2012b) in Alabama flew farther east to Lake Erie and Lake Ontario, as well as to the Mid-Atlantic coast.

The team calculated and compared home ranges during the migration period, which, to every team member's knowledge, has not been done before. The team used Dorr et al. (2012) to determine breeding, migration, and wintering periods for cormorants nesting on the Great Lakes. The period for fall migration (July 13 - October 31) (Dorr et al. 2012) was the longest time period, and permitted the largest number of satellite locations (see Table 5). However, these dates may require some modification in future analyses. First, several birds from both colonies moved shortly after capture and remained in other areas for periods of 4-6 weeks or longer. Examples 
include birds that moved from Baker's Lake to Green Bay, WI, and Detroit, MI (see Table 2). While it is not known whether these birds attempted another breeding effort (since birds were originally captured at active nest sites, any additional attempt would be considered double-brooding events), the possibility must be considered likely since these birds are known to make occasional second nesting attempts (Dorr et al. 2014). Several of these birds did not begin moving to southern wintering areas until later in September. Once the birds moved, most traveled the distance from breeding areas to the MAV within 1 to 2 weeks; therefore, the migration home ranges and the mean distance moved during migration could be biased by some birds essentially still in an active breeding period. Discrepancies in seasonal dates (e.g., overlap between migration and breeding and/or wintering periods), plus variation in daily movements exhibited by birds while foraging, likely explains the lack of significant differences among seasonal kernel home range estimates (see Table 5) and bearing values (see Table 4). Also, movements of birds on both colonies shortly after captures were significant, which likely altered perceptions of typical bird movements during nesting attempts. Results from this study indicate that birds moved frequently at greater distances during the breeding (e.g., Baker's Lake) or wintering season (e.g., TNC Preserve) (see Table 4) than they did during the migration season. This result is likely due to both the movements of some cormorants after capture and the discrepancies of other cormorants remaining relatively stationary during large portions (e.g., August and September) of the migration season dates.

King et al. (2012a, b) found few differences among adult and immature birds, and speculated that some degree of the variation observed in daily movement patterns may be due to gender differences. Here, the team used a genetic sexing procedure to determine the gender of captured birds and to make comparisons between various metrics. Overall, the team found few differences among gender. In general, females tended to have higher mean movement distance during the breeding and migration seasons, while males had a higher $50 \%$ kernel home range estimate during the breeding season. Although sample size was very small, and no statistical significance was found (see Table 7), females had much higher kernel home range estimates during the winter. Females may have to move more frequently within their territory to meet daily nutritional requirements for feeding both the young and themselves during the breeding season. While males and females generally make equal efforts during raising of young (Dorr et al. 2014), males may move more widely (hence, slightly larger 
breeding ranges) for territory defense, or some differential behavior is keeping females closer to the nesting site. Perhaps competition exists between sexes during the wintering season where aggressive males have some advantage and pressure females to exhibit wider and more frequent movements. Reasons for larger kernel home ranges observed for females during the winter in this study are not known, and more research with larger sample sizes are needed.

Finally, at the end of the study, some additional information on several birds became available. One satellite tag (\#119212) for a bird captured and tagged at Baker's Lake was found and returned during the winter of 2013. The satellite tag was found at Lake Bogue Homa, just west of Laurel, MS, indicating that this was one bird that spent some portion of the wintering season just east of the MAV and LA coast. Also, in May 2013, satellite tag (\#119206) inexplicitly began retransmitting a signal. The team again used the online data download option from CLS America, Inc., and followed the cormorant for approximately five weeks from early May to mid-June 2013. Why this tag began retransmitting is unknown, but there have been prior occurrences from Sirtrack transmitters (pers. comm., Mike van den Tillart, Lotek/Biotrack/Sirtrack, June 15, 2013, via email communication). During 2013, this cormorant was located north of Baker's Lake, and remained in and around the Aurora, IL, near the Fox River (about 25 miles south of Baker's Lake) for about 3 weeks.

\section{Ideas for Future Research Involving Piscivorous Birds and Asian Carp eDNA}

1. The authors recommend testing various lakes and ponds in and around the CAWS, especially Baker's Lake and Lake Renwick. Initially, invasive carp DNA results should be negative during the winter months. As cormorants begin returning to the artificial nesting structures in early spring, one would expect that positive invasive carp DNA results would be found in fecal material sampled using swabs from active nests in the Baker's Lake and/or Lake Renwick colonies. As the season progresses, water samples collected from these lakes should also begin showing positive DNA results for invasive carp. This natural experiment would be similar to the enclosed ponded water habitats tested by the USGS (see ACRCC 2013), and would provide further evidence that piscivorous birds are likely important vectors of invasive carp DNA in the CAWS. 
2. Currently, we have a poor understanding of the number of invasive carp DNA copies excreted in fecal material daily by cormorants ${ }^{1}$. Moreover, uncertainty exists on degradation rates of carp DNA once the fecal material is deposited into the water column. Currently, it is assumed that invasive carp DNA imbedded in cormorant fecal material likely consists of the refractory or slow-degrading DNA (ACRCC 2013); however, this assumption should be verified. A study that uses captured cormorants and initiates experimental trials that will include controlled diets of invasive carp, along with laboratory research on the amount of carp DNA copies per unit gram of fecal material, and a concurrent study of carp DNA decomposition rates in fecal material when deposited in water, would provide a better understanding of how piscivorous birds are contributing to the presence and persistence of invasive carp DNA in the CAWS.

3. During a discussion, Dr. Jon Amberg, Research Fish Biologist, USGS Upper Midwest Environmental Sciences Center, suggested research using piscivorous birds as an indicator group showing the movements of an invasive species (in this case, invasive carp) through the environment. This research would serve as a proof-of-concept, and may be relevant to other invasive species. The idea focuses on differential daily and/or seasonal movements of most birds, where collection of fecal samples (e.g., at nesting sites) would be collected first from cormorants (because they are one of the most wide-ranging species). Once cormorant feces begin to show positive results for invasive carp, then testing would shift towards other piscivorous species (e.g., Great Blue Heron, Great Egret) with a more moderate movement behavior and lower population density, and finally, testing would begin on species with more localized behavior (e.g., Snowy Egret, Belted Kingfisher (Megaceryle alcyon)). The general idea is that northern invasive carp spawning populations near Peoria, IL, would complete the breeding cycle in early spring, and then begin to move northward along the Illinois River. This movement should be detectable in piscivorous birds. One would hypothesize that invasive carp eDNA would first become noticeable in cormorants, and then as the season progresses and young carp move northward, other piscivorous birds would start including them in their diets and start showing positive carp DNA in their feces. These data would allow the team to verify the patterns and timing of annual movements of invasive carp and a more comprehensive view of piscivorous birds as carp DNA vectors in the CAWS. The timing and

\footnotetext{
1 Guilfoyle, M. P., and M. T. Schultz. (In review). The contribution of double-crested cormorants (Phalacrocorax auritus) to silver carp (Hypophthalmichthys molitrix) DNA loads in the Chicago Area Waterway System. The Journal of Great Lakes Research.
} 
patterns of positive Asian carp DNA in bird feces should also be highly correlated with ongoing fish sampling and carp eDNA monitoring efforts in the CAWS. As a proof-of-concept, such research may be applicable to other existing or future invasive species, and may show an expanded application of eDNA monitoring in the study of invasive species generally.

4. Personal communication with Doug Stotz, of The Field Museum, Chicago, Oct 10, 2013, via email indicates that hundreds - and potentially thousands - of cormorants roost along the Lake Michigan shoreline during the migration and breeding seasons. The potential role of migrating, or non-breeding cormorants, contributing to invasive carp DNA deposition in the CAWS is unknown. First, more standardized population size, distribution, and habitat utilization data need to be collected for better population estimates ${ }^{1}$. Then, non-breeding cormorants could be captured and tested through the use of throat and cloacal swabs, as demonstrated by Guilfoyle et al. (2017). With sufficient sample sizes (e.g., $>40$ cormorants per season), the number of captured, non-breeding cormorants showing positive results for carp in their swabs could be included in existing models of invasive carp DNA deposition by secondary sources in the CAWS (Schultz et al. 2014). These data would remove existing uncertainty inherent in these models and may provide further insight into the role of piscivorous birds as vectors of invasive carp DNA in the CAWS.

\footnotetext{
1 Guilfoyle, M. P., and M. T. Schultz. (In review). The contribution of double-crested cormorants (Phalacrocorax auritus) to silver carp (Hypophthalmichthys molitrix) DNA loads in the Chicago Area Waterway System. The Journal of Great Lakes Research.
} 


\section{References}

Andrews, D. W., G. S. Fraser, and D. V. Weseloh. 2012. Double-Crested Cormorants during the chick-rearing period at a large colony in southern Ontario: analyses of chick diet, feeding rates and foraging direction. Waterbirds (Special Publication 1) $35: 82-90$.

Asian Carp Regional Coordinating Committee (ACRCC). 2013. Environmental DNA Calibration Study (ECALS), $2^{\text {nd }}$ Interim Technical Report. Kelly Baerwaldt, Editor, U.S. Army Corps of Engineers. http://www.asiancarp.us/ecals.htm. Accessed 9 October 2015.

ACRCC. 2014. ECALS, $3^{\text {rd }}$ Interim Technical Report. Kelly Baerwaldt, Editor, U.S. Army Corps of Engineers. http://www.asiancarp.us/ecals.htm. Accessed June 24, 2015.

Bart, J., A. Manning, L. Dunn, R. Fischer, and C. Eberly. 2012. Coordinated Bird Monitoring: Technical Recommendations for Military Lands. U.S. Geological Survey Open-File Report 2010-1078, 68p.

CLS America, Inc. 2008. Argo's User's Manual: Worldwide Tracking and Environmental Monitoring by Satellite. Lanham, MD.

Dejean, T., A. Valentini, A. Duparc, S. Pellier-Cuit, F. Pompanon, P. Taberlet, and C. Miaud. 2011. Persistence of Environmental DNA in freshwater ecosystems. PloS ONE: 6(8): e23398. Doi:101371/journal.pone.0023398.

Dorr, B. S., J. J. Hatch, and D. V. Weseloh. 2014. Double-Crested Cormorant (Phalacrocorax auritus). In The Birds of North America, No. 441 (A. Poole and F. Gill, eds.). The Birds of North America, Inc., Philadelphia, PA.

Dorr, B. S., C. Somers. 2012. The direction of research and management of DoubleCrested Cormorants heading into the 200os: symposium overview and future information needs. Waterbirds (Special Publication 1) 35:138-148.

Dorr, B. S., T. Alderman, P. H. Butchko, and S. C. Barras. 2010a. Management effects on breeding and foraging numbers and movements of Double-Crested Cormorants in the Les Cheneaux Islands, Lake Huron, Michigan. Journal of Great Lakes Research 36:224-231.

Dorr, B. S., A. Moerke, M. Bur, C. Bassett, T. Aderman, D. Traynor, R. Singleton, P. Butchko, and J. D. Taylor II. 2010b. Evaluation of harassment of migrating Double-Crested Cormorants to limit depredation on selected sport fisheries in Michigan. Journal of Great Lakes Research 36:213-223.

Dorr, B. S., J. D. Taylor, II, S. J. Werner, D. T. King, J. F. Farquhar, I. M. Mazzocchi, and R. D. McCullough. 2012. Summer and migrational movements of satellitemarked Double-Crested Cormorants from a breeding colony managed by eggoiling in Lake Ontario, USA. Waterbirds (Special Publication 1) 35:114-1123.

Guilfoyle. M. P., H. L. Farrington, R. F. Lance, K. C. Hanson-Dorr, B. S. Dorr, and R. A. Fischer. 2017. Movement of Hypophthalmichthys DNA in the Illinois Watershed by the Double-crested Cormorant (Phalacrocorax auritus). Waterbirds 40:63-68. 
Guillaumet, A., B. Dorr, G. Wang, J. D. Taylor, R. B. Chipman, H. Scherr, J. Bowman, K. F. Abraham, T. J. Doyle, and E. Cranker. 2011. Determinants of local and migratory movements of Great Lakes Double-Crested Cormorants. Behavioral Ecology doi:10.1093.

Kernohan, B. J., R. A. Gitzen, and J. J. Millspaugh. 2001. Analysis of animal space use movements. In Radio Tracking and Animal Populations, eds. J. J., Millspaugh and J. M. Marzluff, 125-166. San Diego, CA: Academic Press.

King, D. T. and M. E. Tobin. 200o. Capture and telemetry techniques for Double-Crested Cormorants (Phalacrocorax auritus). Proceedings: Vertebrate Pest Conference 19:54-57.

King, D. T., B. K. Strickland, and A. A. Radomski. 2012a. Winter and summer home ranges and core use areas of Double-Crested Cormorants near aquaculture facilities in the southeastern United States. Waterbirds (Special Publication 1) 35: 124-131.

King, D. T., B. K. Strickland, and A. Radomski. 2012b. Migration patterns of DoubleCrested Cormorants wintering in the southeastern United States. Waterbirds (Special Publication 1) 35:132-137.

Klimaszyk, P., T. Joniak, T., T. Sobczynski, and W. Andrzejewski. 2008. Impact of a cormorant (Phalacrocorax carbo L.) colony on surface water quality. Overland Flow as a factor of nutrient transfer from colony to lake. In The Functioning and Protection of Water Ecosystems, ed. R. Goldyn, P. Klimaszyk, N. KuczyriskaKippen, and R. Piotrowicz, 45-50. Poznan, Poland: Department of Water Protection, Adam Mickiewicz University.

Klimaszyk, P., T. Joniak, and P. Rzymski. 2014. Roosting colony of cormorants (Phalacrocorax carbo sinensis L.) as a source of nutrients for the lake. Limnological Review 14:111-119.

Laver, P. N. 2005. Kernel home range estimation for ArcGIS, using VBA and ArcObjects: Abode User manual (Beta v.2). Virginia Tech, Blacksburg, VA.

Merkes, C. M., S. G. McCalla, N. R. Jenson, M. P. Gaikowski, and J. J. Amberg. 2014. Persistence of DNA in carcasses, slime and avian feces may affect interpretation of environmental DNA data. PloS ONE: 9(11): e113346. doi: $\underline{10.1371 / \text { journal.pone.0113346. }}$.

Monitoring and Response Work Group (MRWG). 2013. 2012 Asian carp monitoring and rapid response plan, interim summary reports, Asian Carp Regional Coordinating Committee (ACRCC).

Nettleship, D. N., and D. C. Duffy. 1995. Cormorants and human interactions: an introduction. Colonial Waterbirds 18 (Special Publication):3-6.

Ridgway, M. S. 2010. A review of estimates of daily energy expenditure and food intake in cormorants (Phalacrocorax spp.). Journal of Great Lakes Research 36:93-99.

SAS Institute. 2006-2010. SAS Enterprise Guide, SAS Institute, Inc. Cary, NC. 
Scherr, H., J. Bowman, and K. F. Abraham. 2010. Migration and winter movements of Double-Crested Cormorants breeding in Georgian Bay, Ontario. Waterbirds 33: 451-460.

Schultz, M. T., C. F. Cerco, B. E. Skahill, R. F. Lance, M. R. Noel, P. K. DiJoseph, D. L. Smith, and M. P. Guilfoyle. 2014. A probabilistic analysis of environmental DNA monitoring results in the Chicago Area Waterway System.

http://www.asiancarp.us/documents/FINAL_REPORT-ALL_ACRCC_Framework_Item_2.6.3. Probabilistic_Model_120314.pdf. Accessed 19 April 2017.

Sparks, R. E., T. L. Barkley, S. M. Creque, J. D. Dettmers, and K. M. Stainbrook. 2010. Evaluation of an electric fish dispersal barrier in the Chicago Sanitary and Ship Canal. American Fisheries Society Symposium 74:139-161.

Tobin, M. E. ed. 1999. Symposium on Double-Crested Cormorants: population status and management issues on the Midwest. Technical Bulletin No. 18979. Fort Collins, CO: U.S. Department of Agriculture, Animal and Plant Health Inspection Service, Wildlife Service, National Wildlife Research Center.

U.S. Fish and Wildlife Service (USFWS). 2015. The Second Annual Report to Congress: Summary of activities and expenditures to manage the threat of Asian carp in the Upper Mississippi and Ohio River basins. July 2014 to September 2015. https://www.fws.gov/midwest/fisheries/asian-carp/WRRDA2015.pdf. Accessed 19 April 2017.

Wires, L. R., and F. J. Cuthbert. 2006. Historic populations of the Double-Crested Cormorant (Phalacrocorax auritus): implications for conservation and management in the $21^{\text {st }}$ century. Waterbirds 29:9-37. 


\section{Appendix A: eBird Distributions of the 10 Most Common Piscivorous Birds from Havana, IL, to the CAWS, 2005-2012}

Figure A1. Distribution of eBird American White Pelican observations from Havana, IL, to the CAWS, 2005-2012.

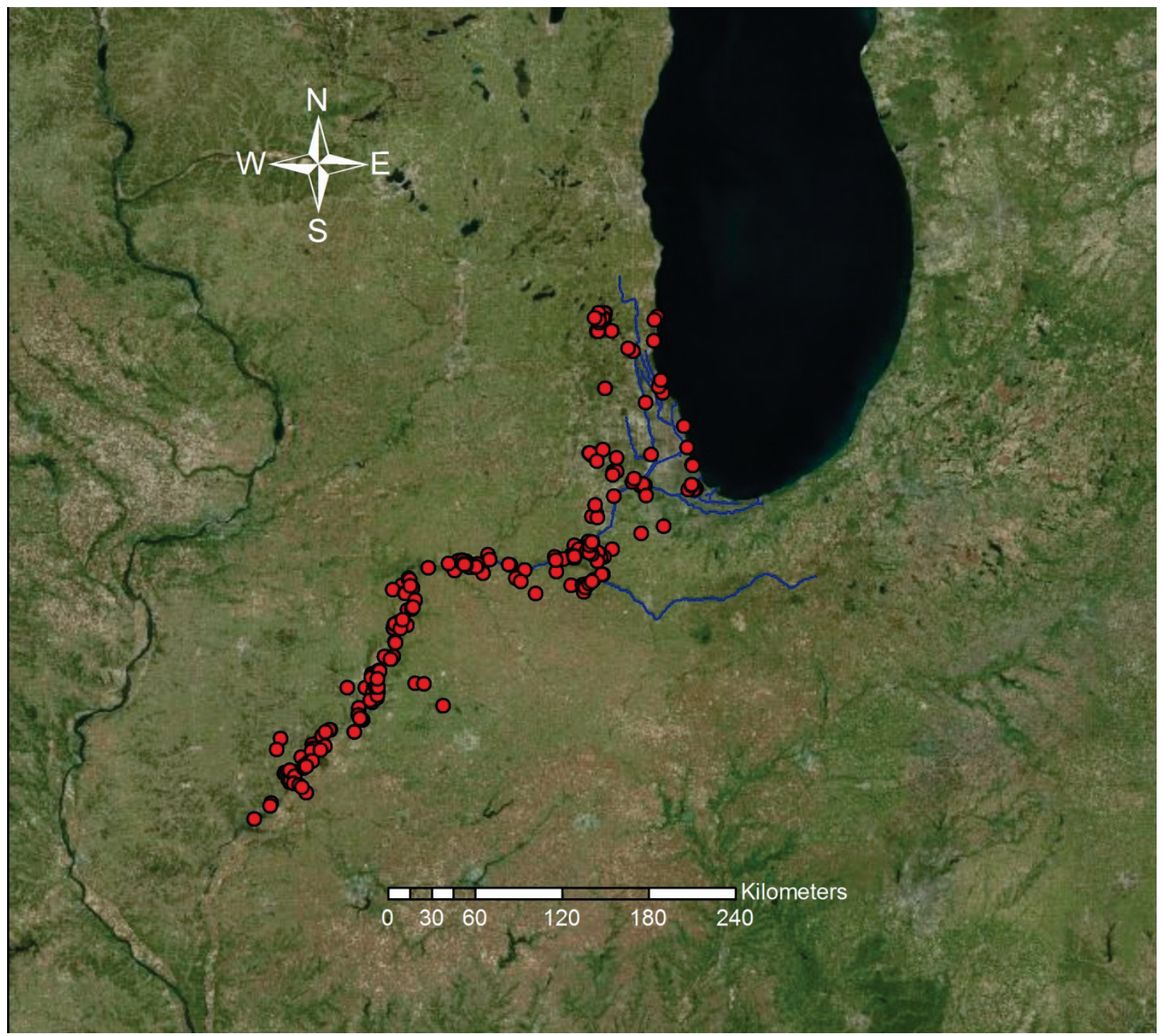


Figure A2. Distribution of eBird Double-Crested Cormorant observations from Havana, IL, to the CAWS, 2005-2012.

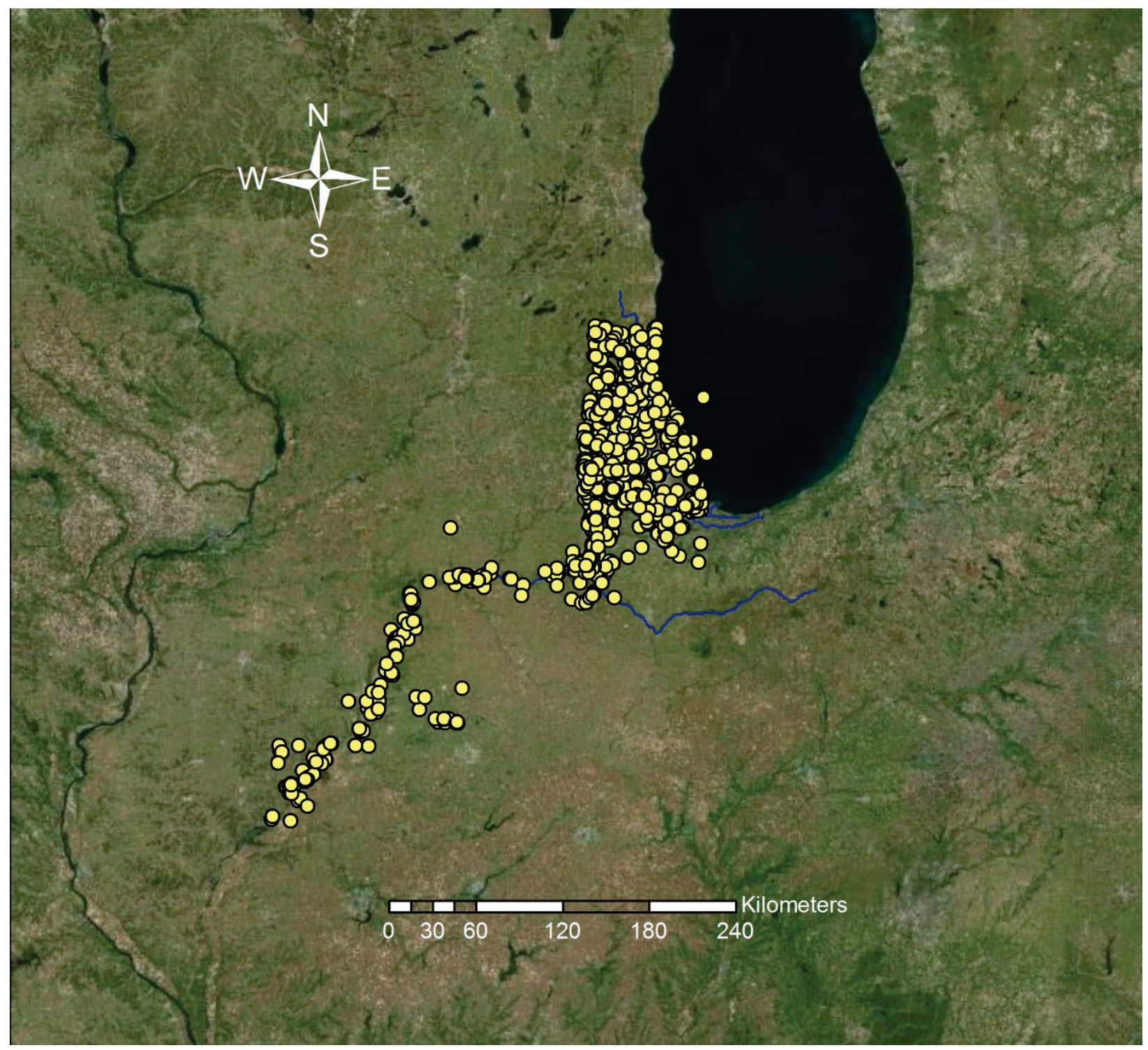


Figure A3. Distribution of eBird Great Blue Heron observations from Havana, IL, to the CAWS, 2005-2012.

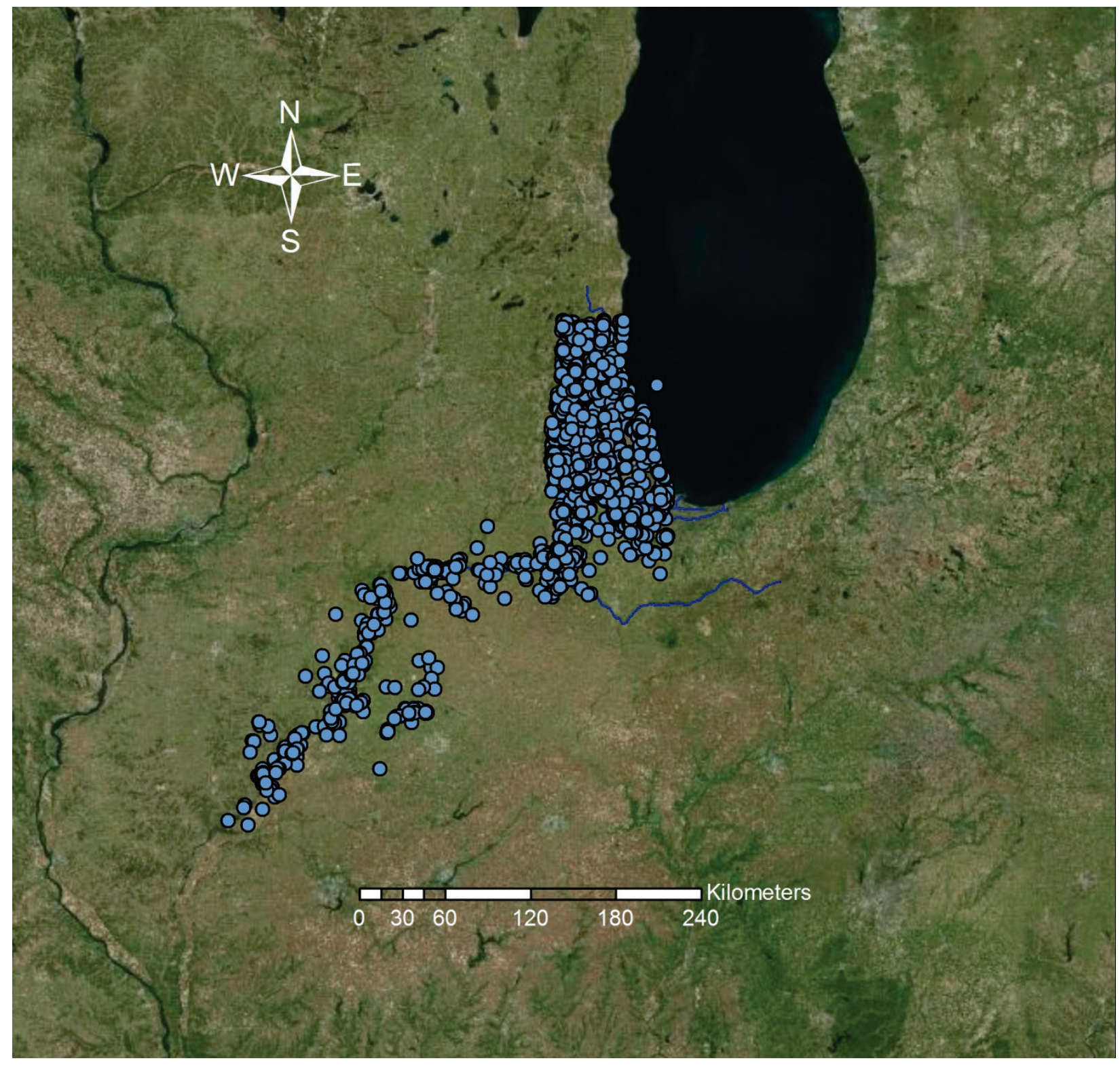


Figure A4. Distribution of eBird Great Egret observations from Havana, IL, to the CAWS, 2005-2012.

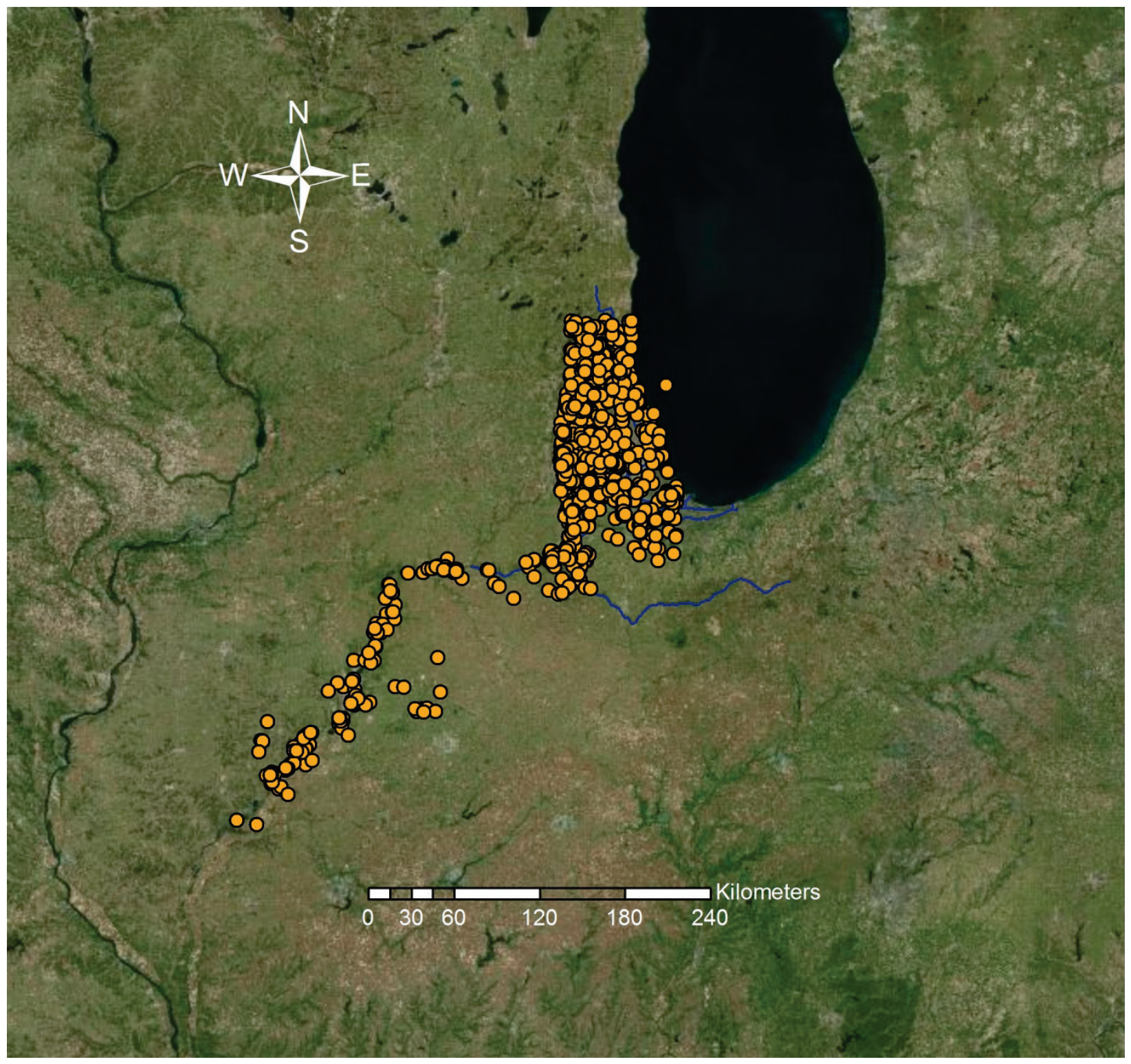


Figure A5. Distribution of eBird Snowy Egret observations from Havana, IL, to the CAWS, 2005-2012.

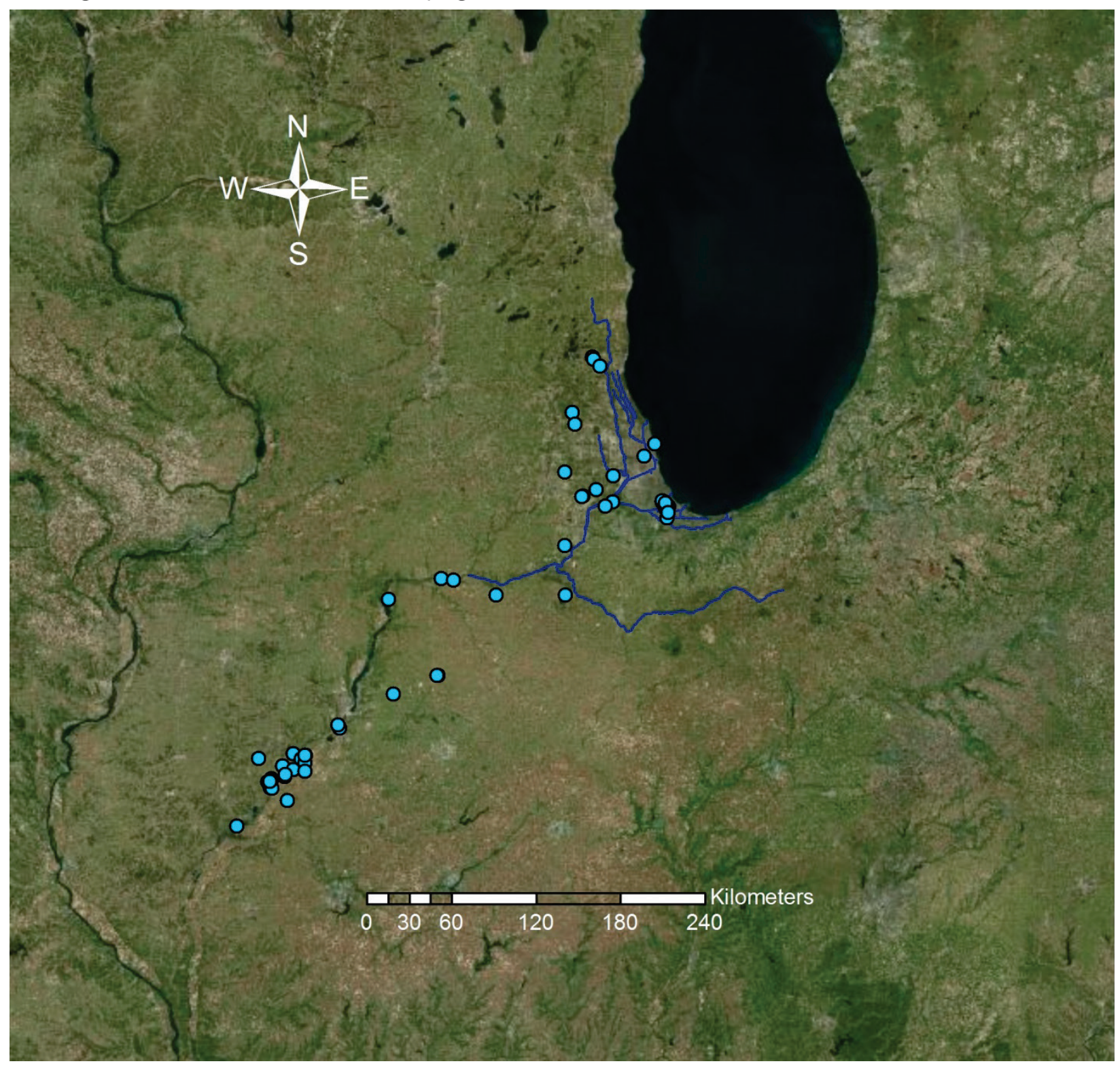


Figure A6. Distribution of eBird Little Blue Heron observations from Havana, IL, to the CAWS, 2005-2012.

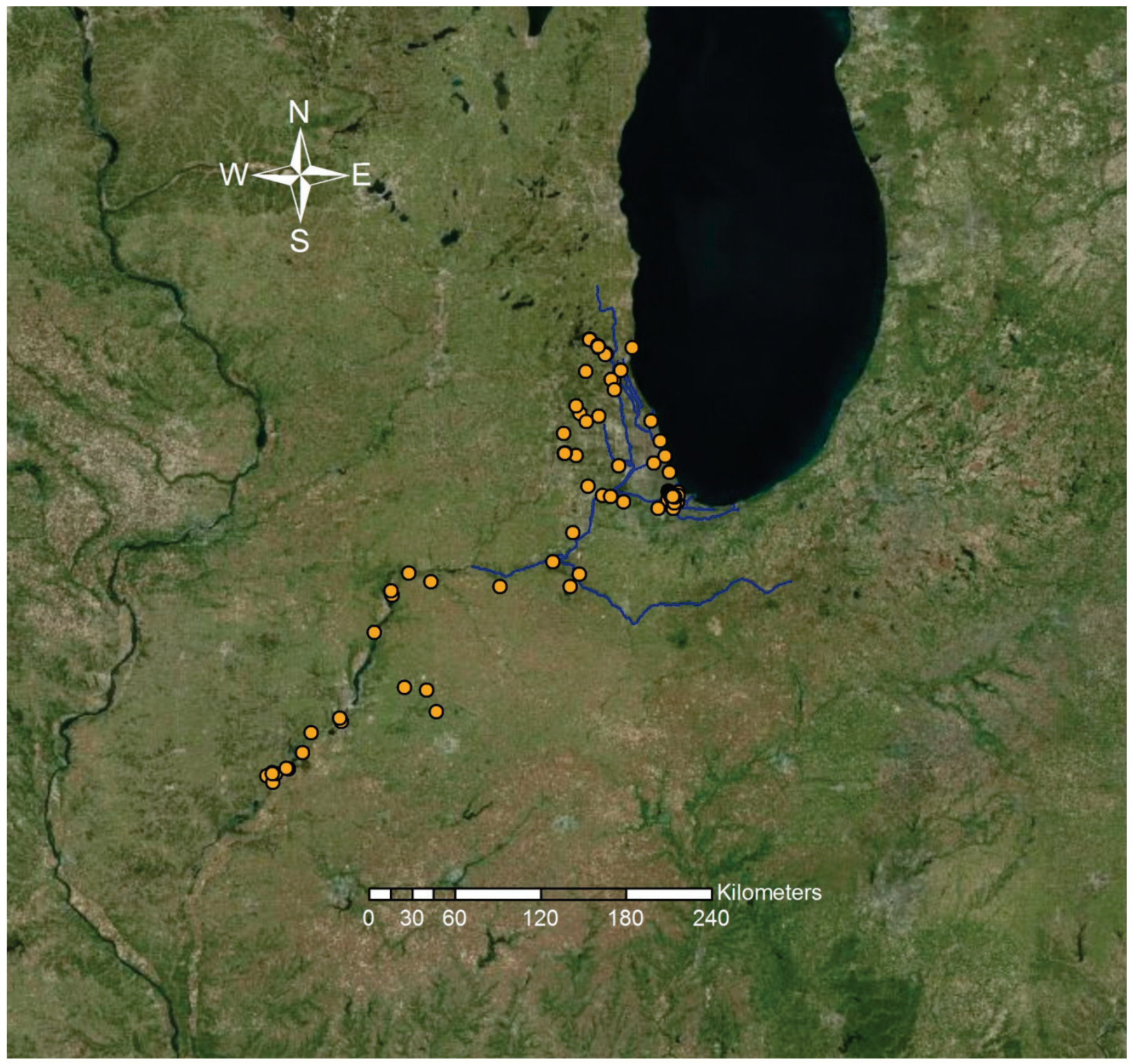


Figure A7. Distribution of eBird Green Heron observations from Havana, IL, to the CAWS, 2005-2012.

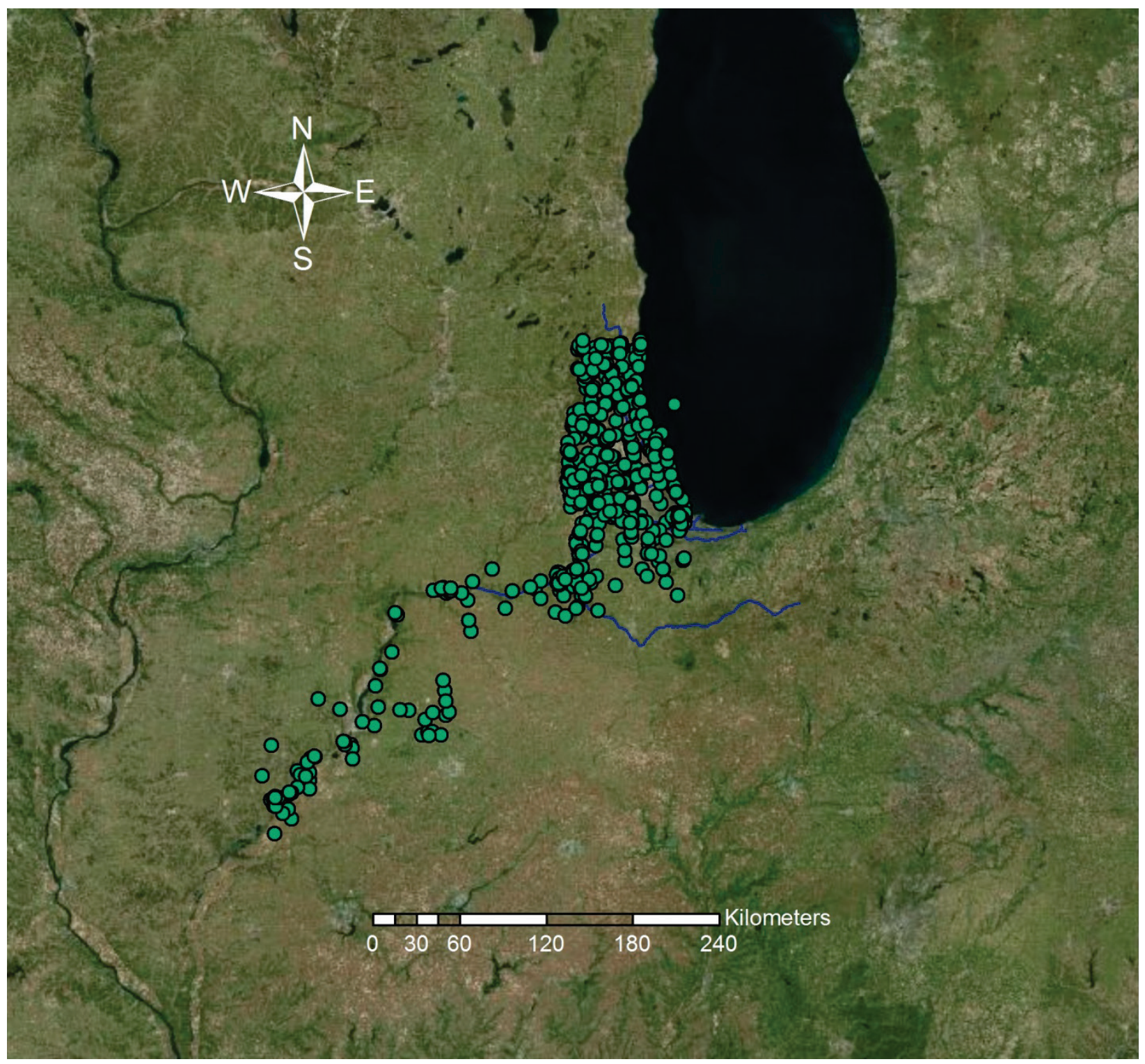


Figure A8. Distribution of eBird Black-Crowned Night-Heron observations from Havana, IL, to the CAWS, 2005-2012.

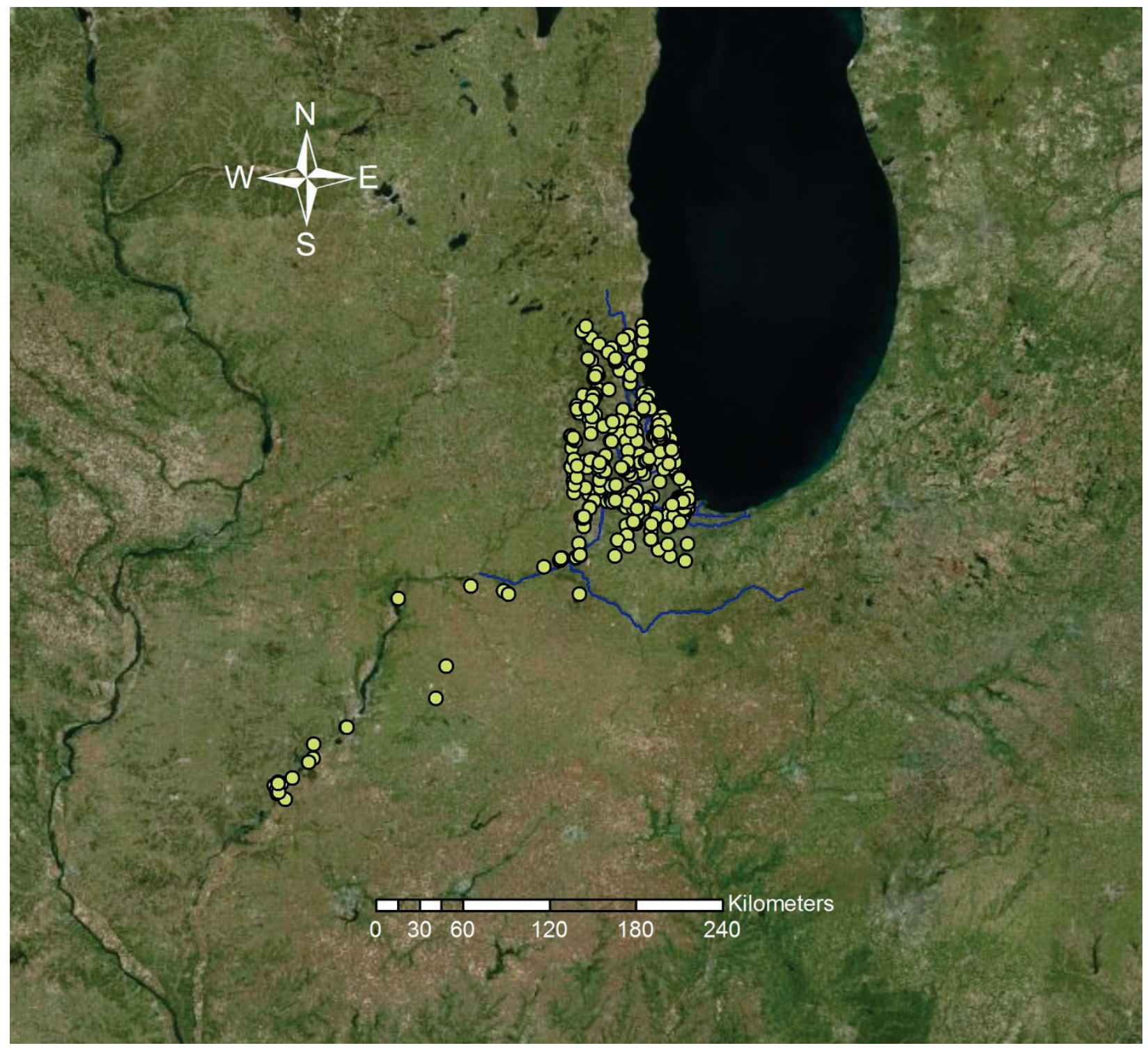


Figure A9. Distribution of eBird Bald Eagle observations from Havana, IL, to the CAWS, 2005-012.

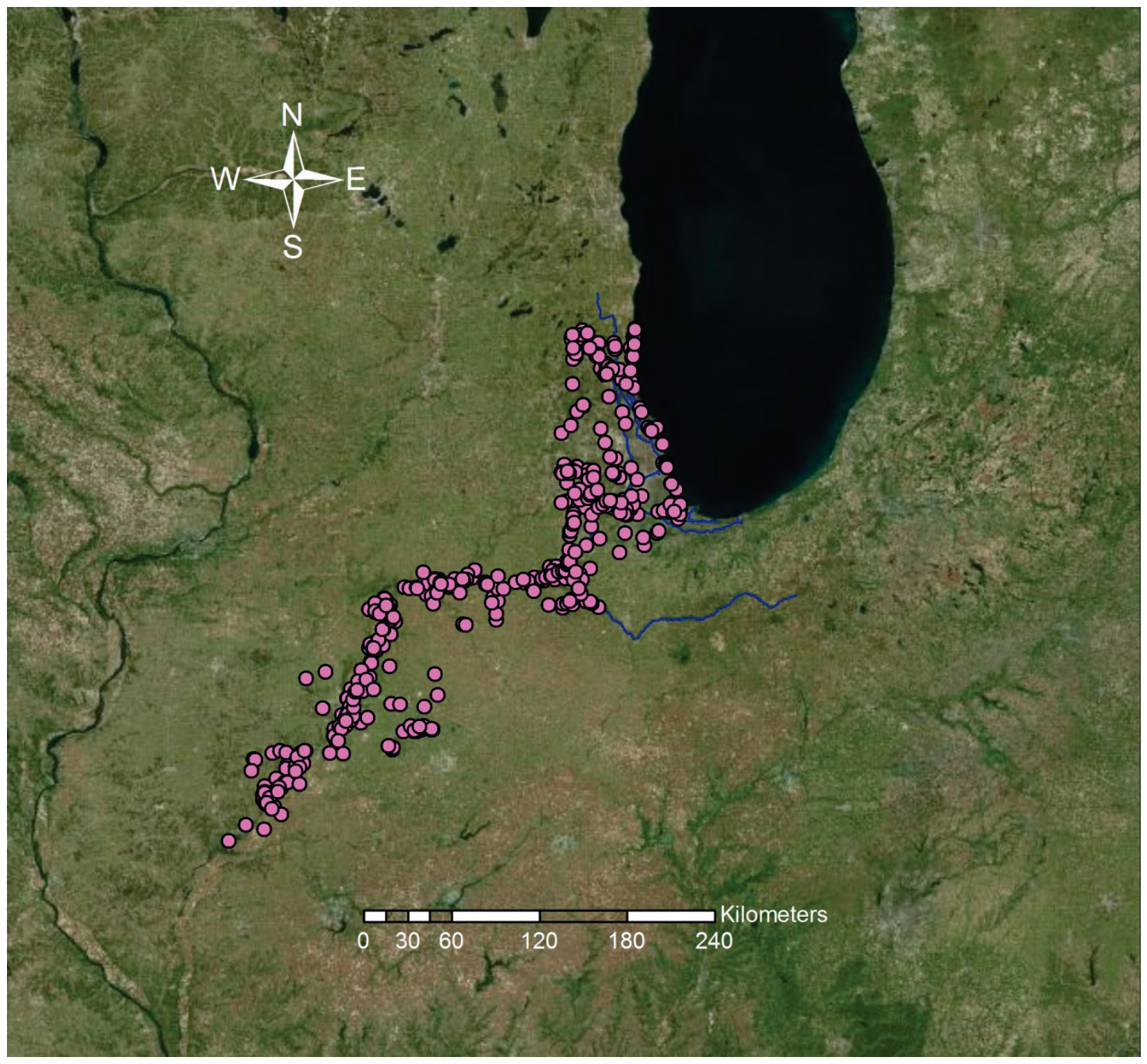


Figure A10. Distribution of eBird Osprey observations from Havana, IL, to the CAWS, 2005-2012.

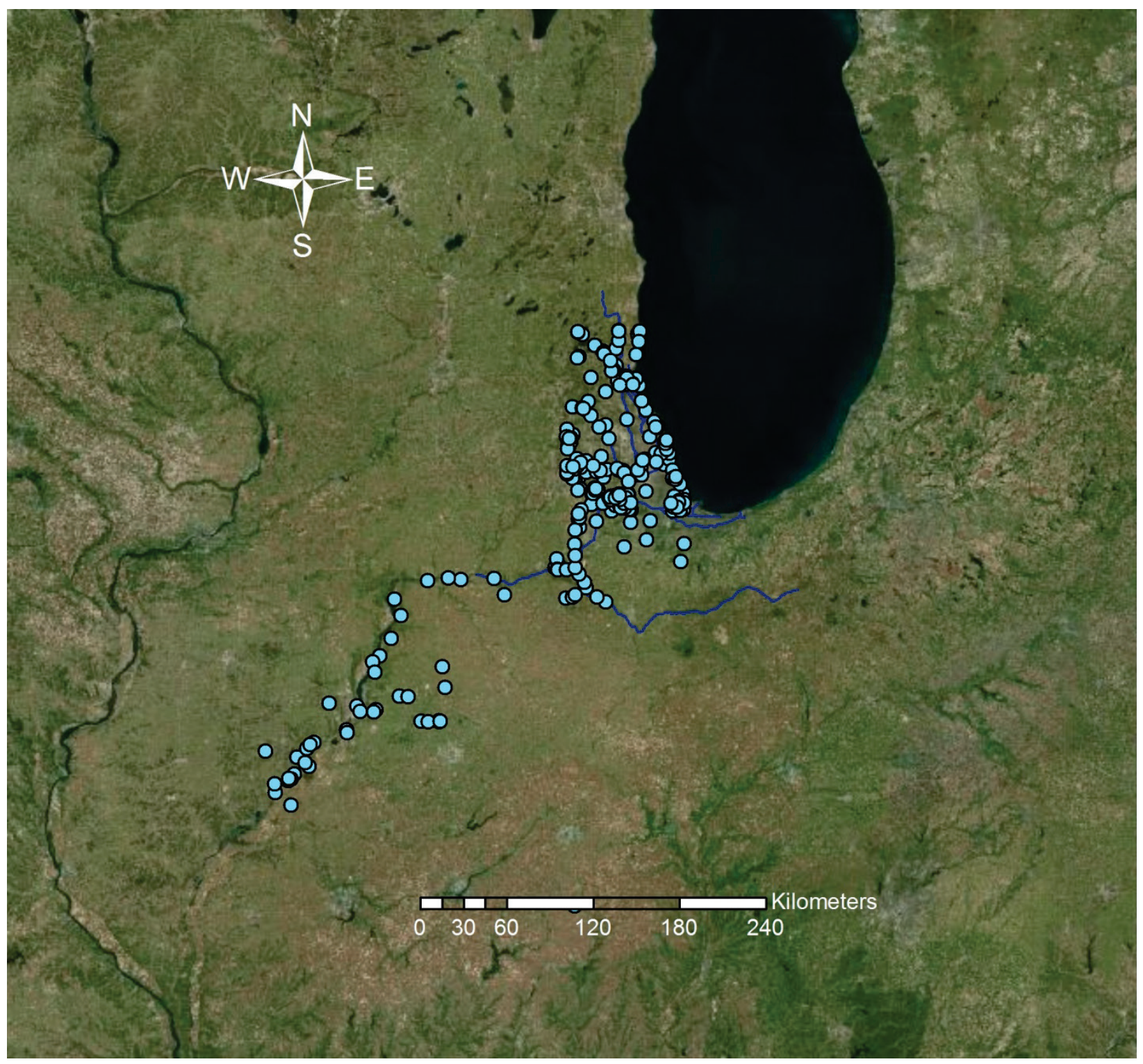




\section{Appendix B: Seasonal 95\% and $50 \%$ Kernel Home Range Polygons for All Cormorants Captured and Tagged at Baker's Lake and the TNC Emiquon Preserve, 2012}

Figure B1. 95\% kernel home range polygons for 14 breeding cormorants from Baker's Lake, May 26 - July 12, 2012.

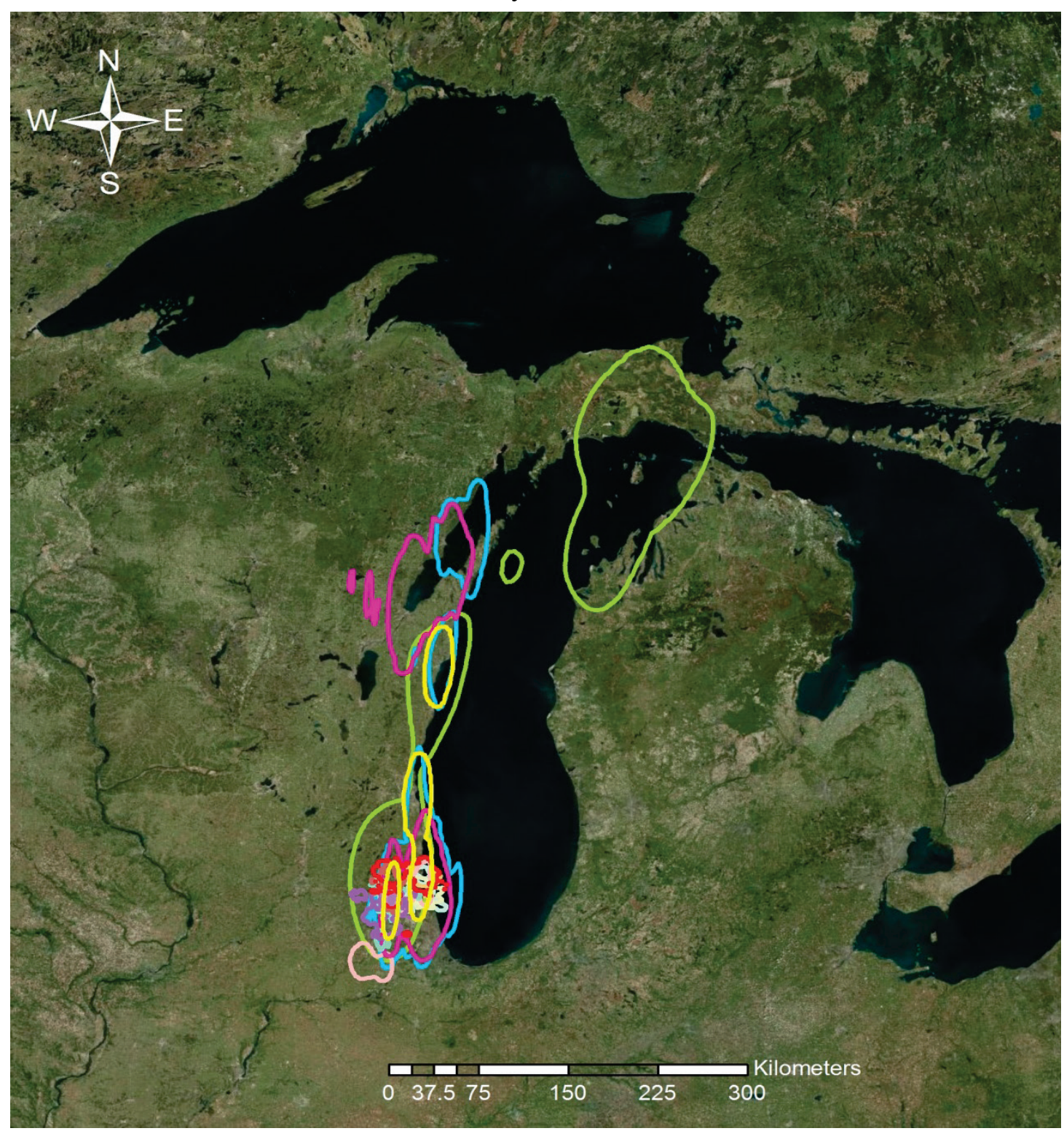


Figure B2. 50\% kernel home range polygons for 14 breeding cormorants from Baker's Lake, May 26 - July 12, 2012.

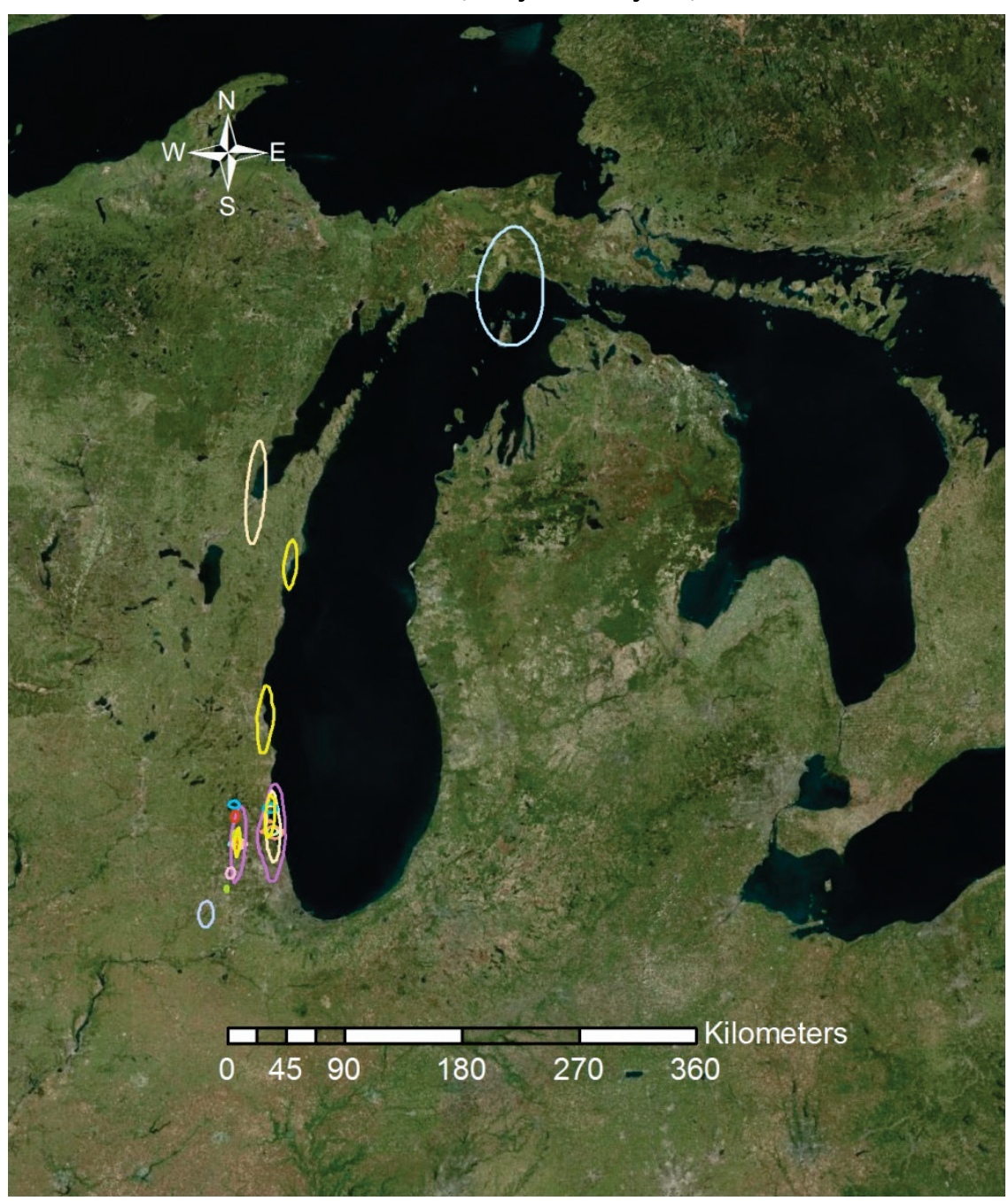


Figure B3. 95\% kernel home range polygons for 15 breeding cormorants from TNC Emiquon Preserve, May 26 - July 12, 2012.

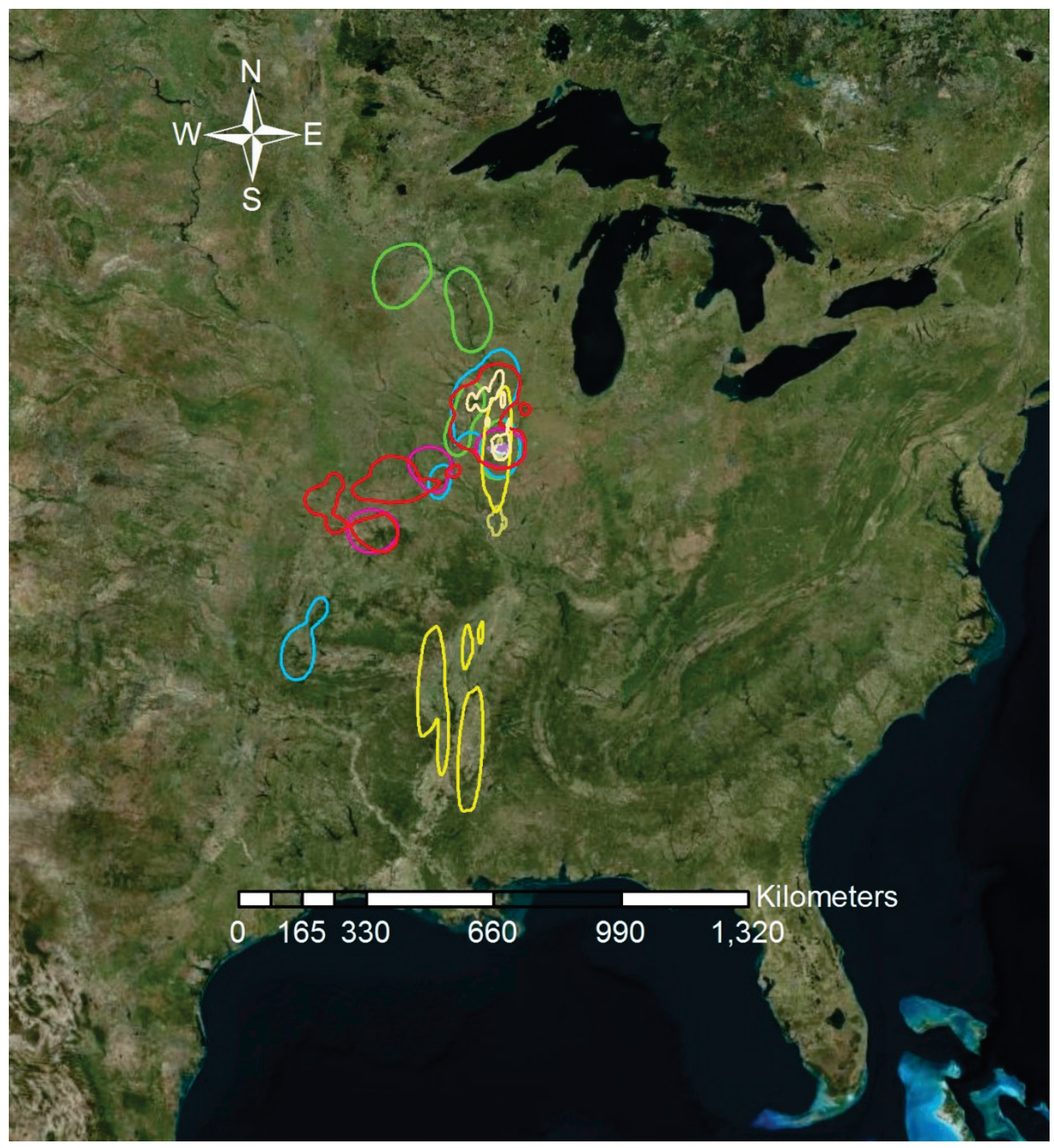


Figure B4. 50\% kernel home range polygons for 15 breeding cormorants from TNC Emiquon Preserve, May 26 - July 12, 2012.

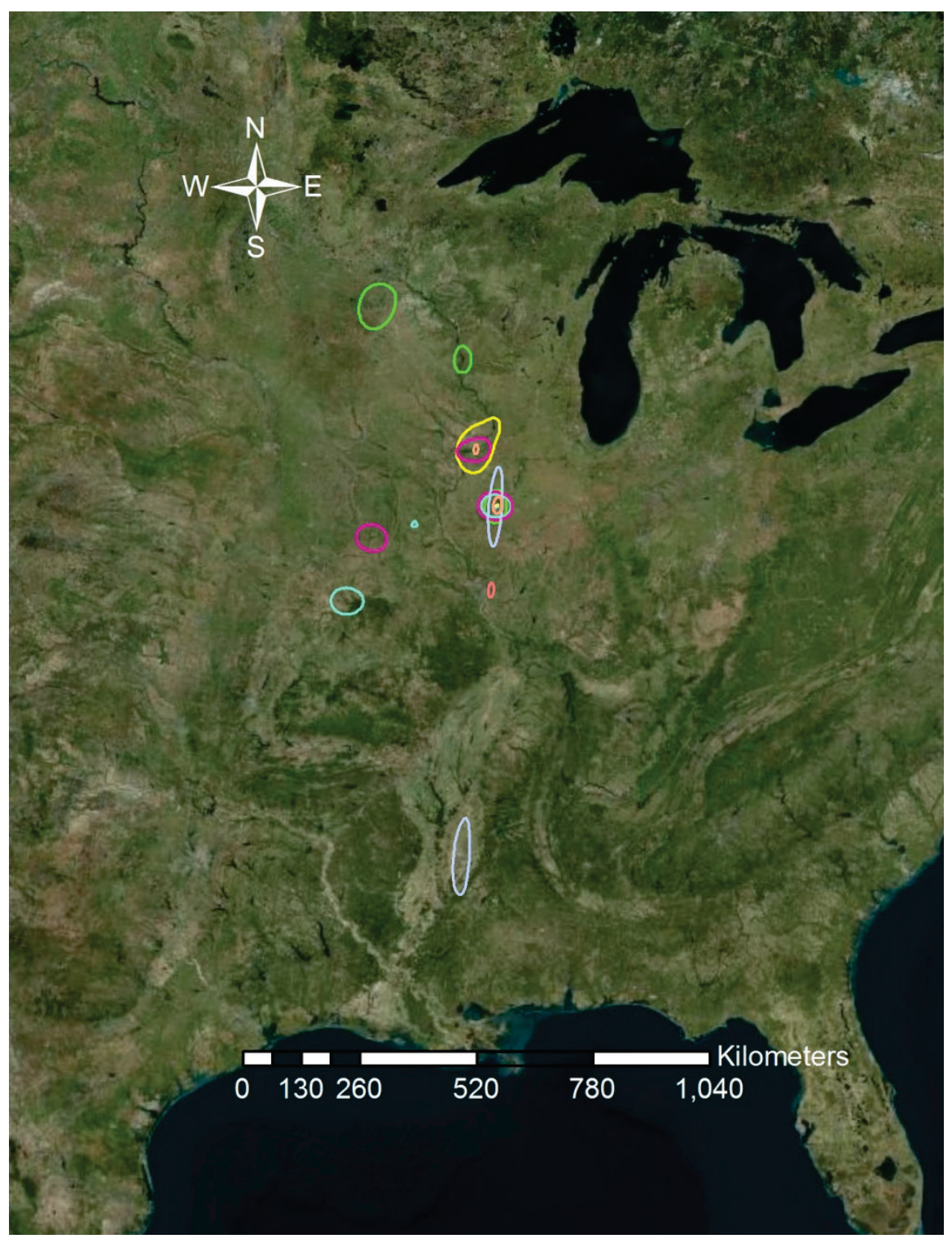


Figure B5. 95\% kernel home range polygons for 8 migrating cormorants from Baker's Lake, July 12 - October 31, 2012.

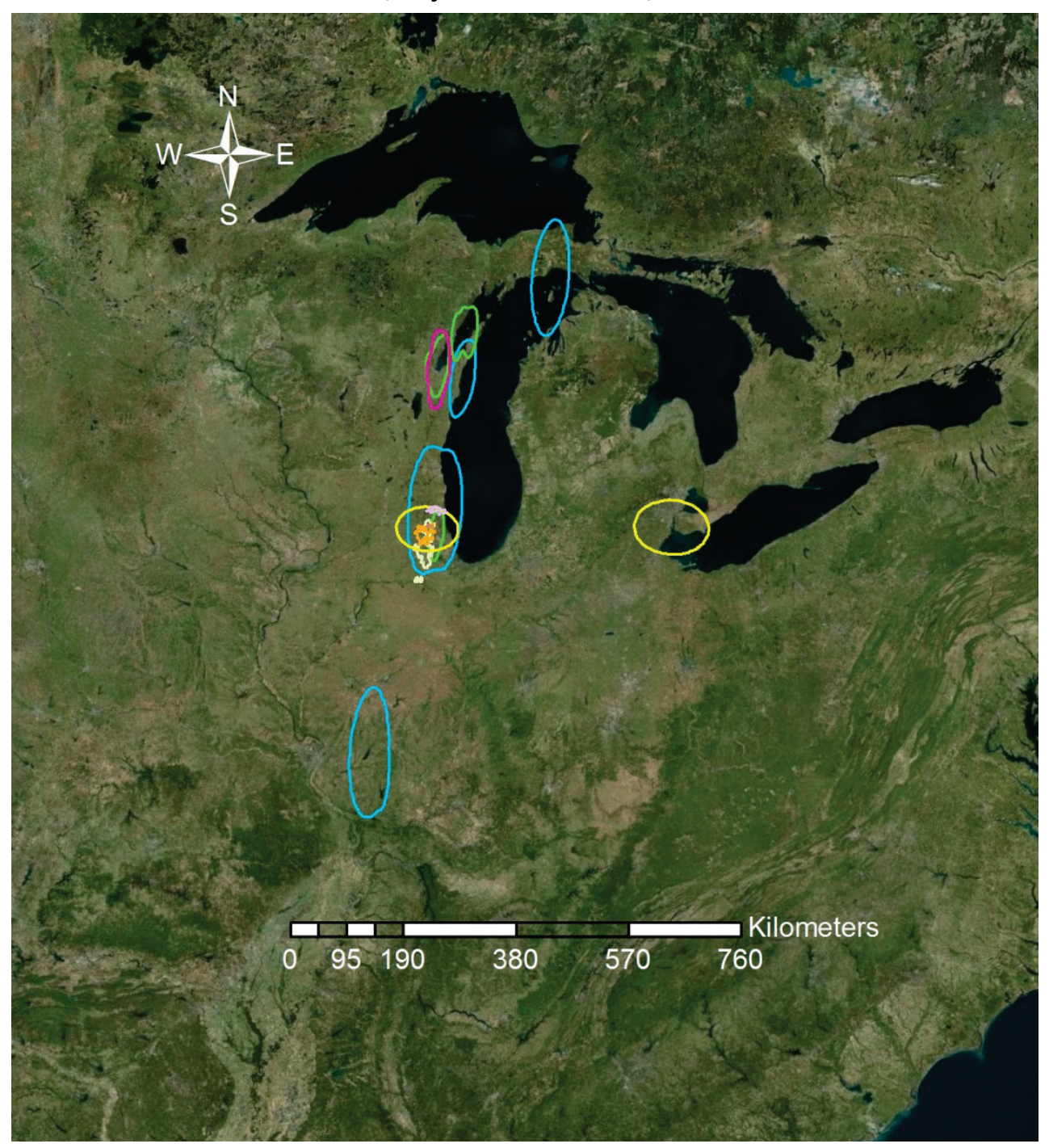


Figure B6. 50\% kernel home range polygons for 8 migrating cormorants from Baker's Lake, July 13 - October 31, 2012.

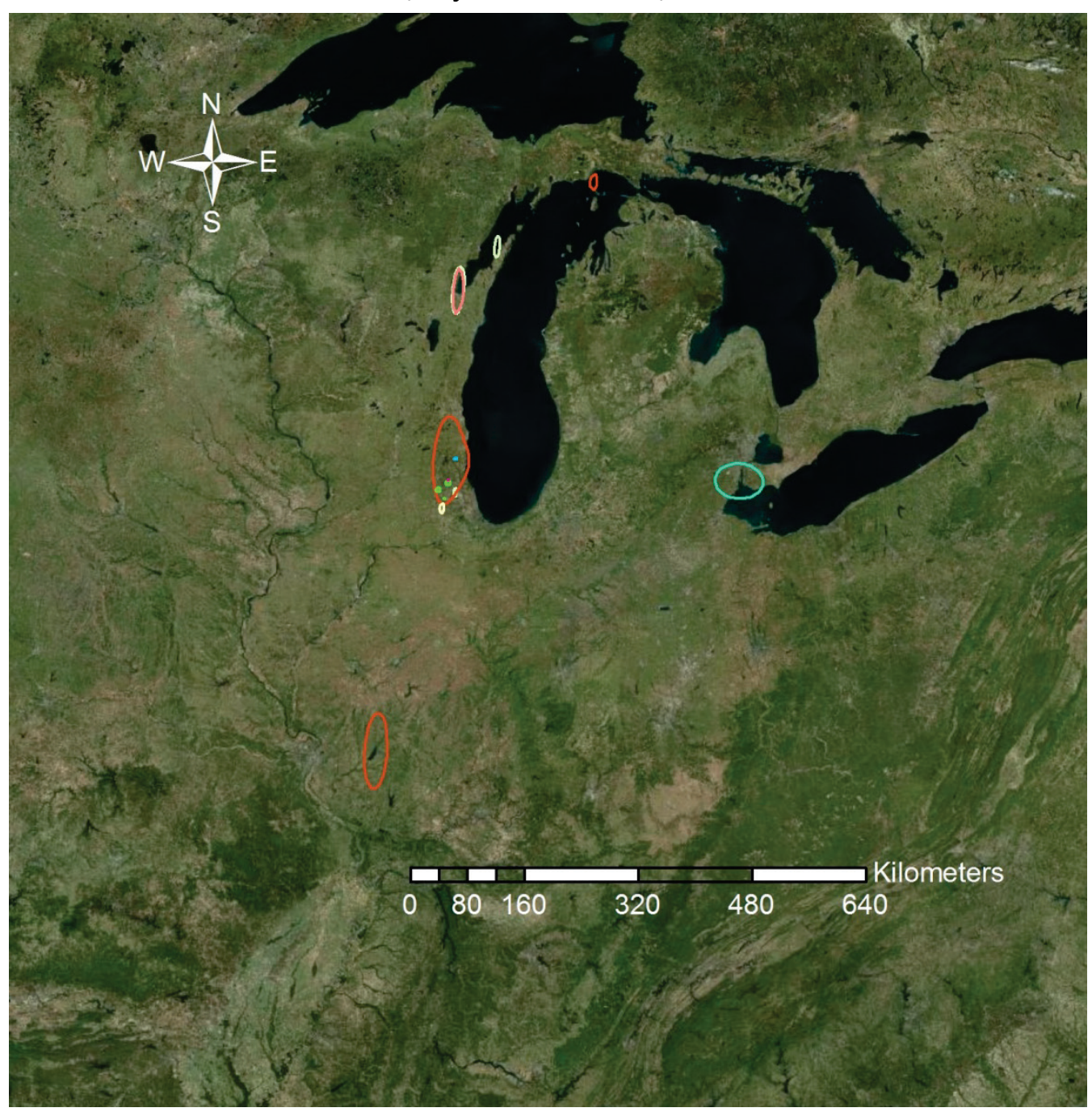


Figure B7. 95\% kernel home range polygons for 8 migrating cormorants from TNC Emiquon Preserve, July 12 - October 31, 2012.

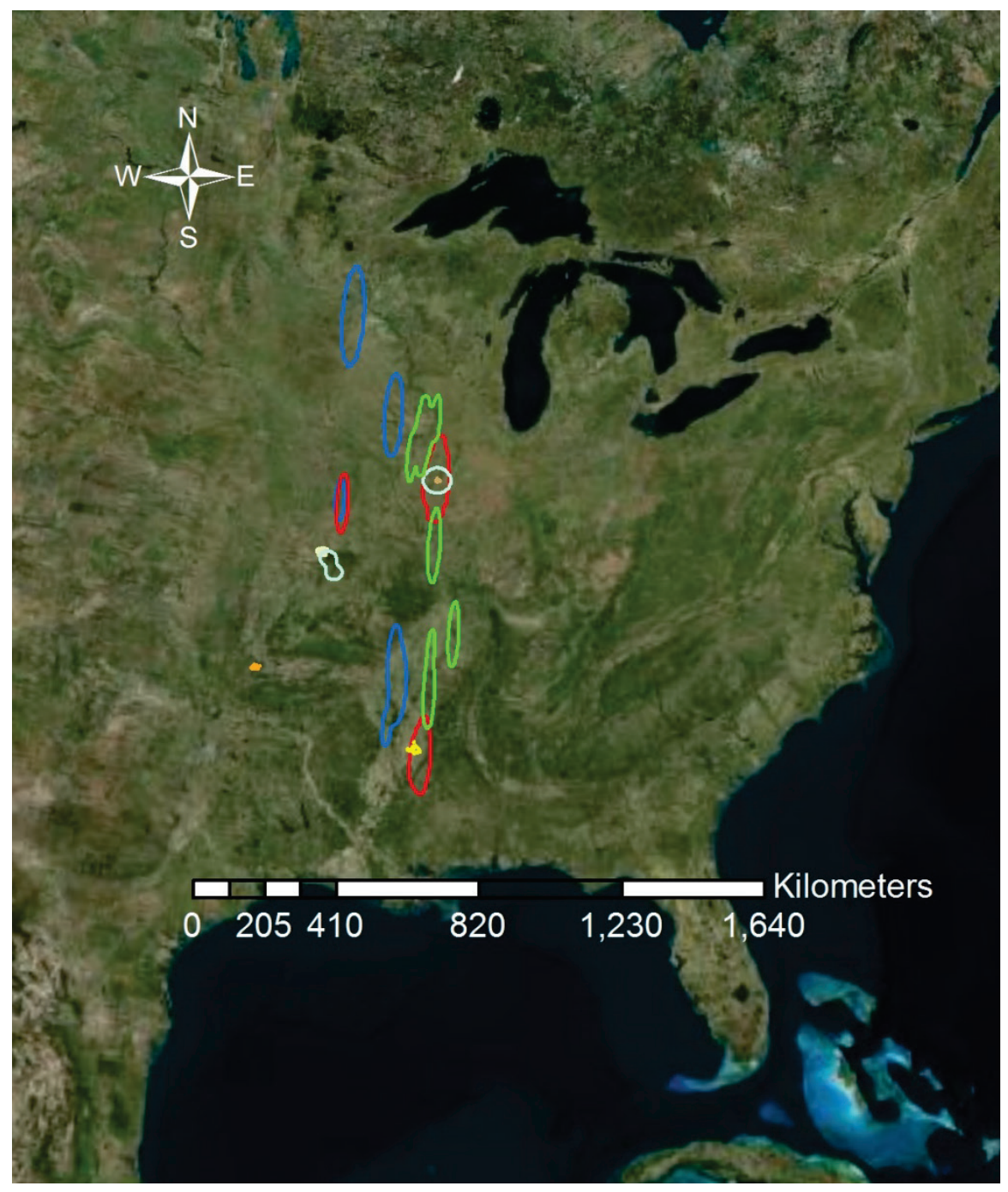


Figure B8. 50\% kernel home range polygons for 8 migrating cormorants from TNC Emiquon Preserve, July 12 - October 31, 2012.

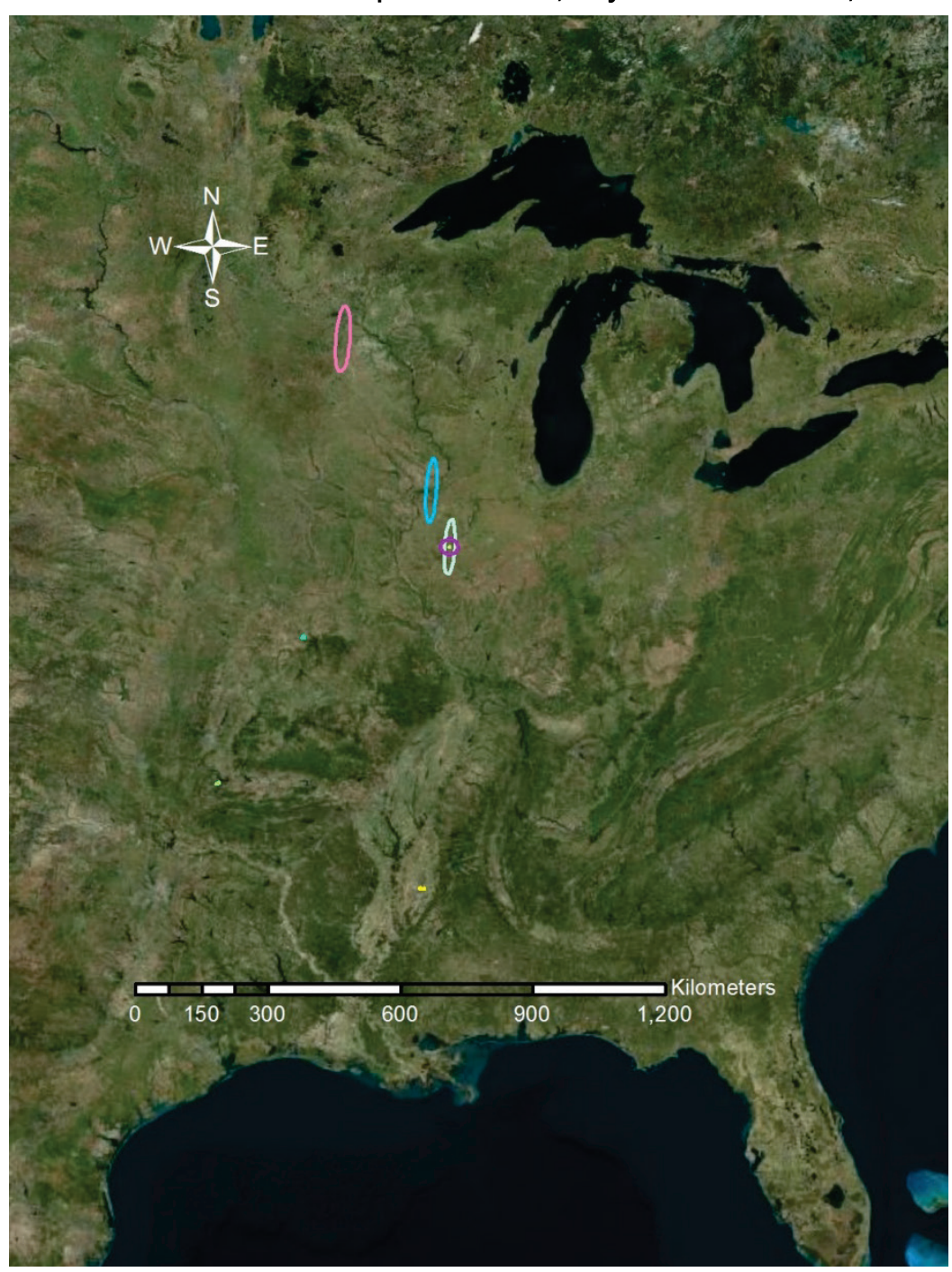


Figure B9. 95\% kernel home range polygons for 4 wintering cormorants from Baker's Lake, November 1 - December 24, 2012.

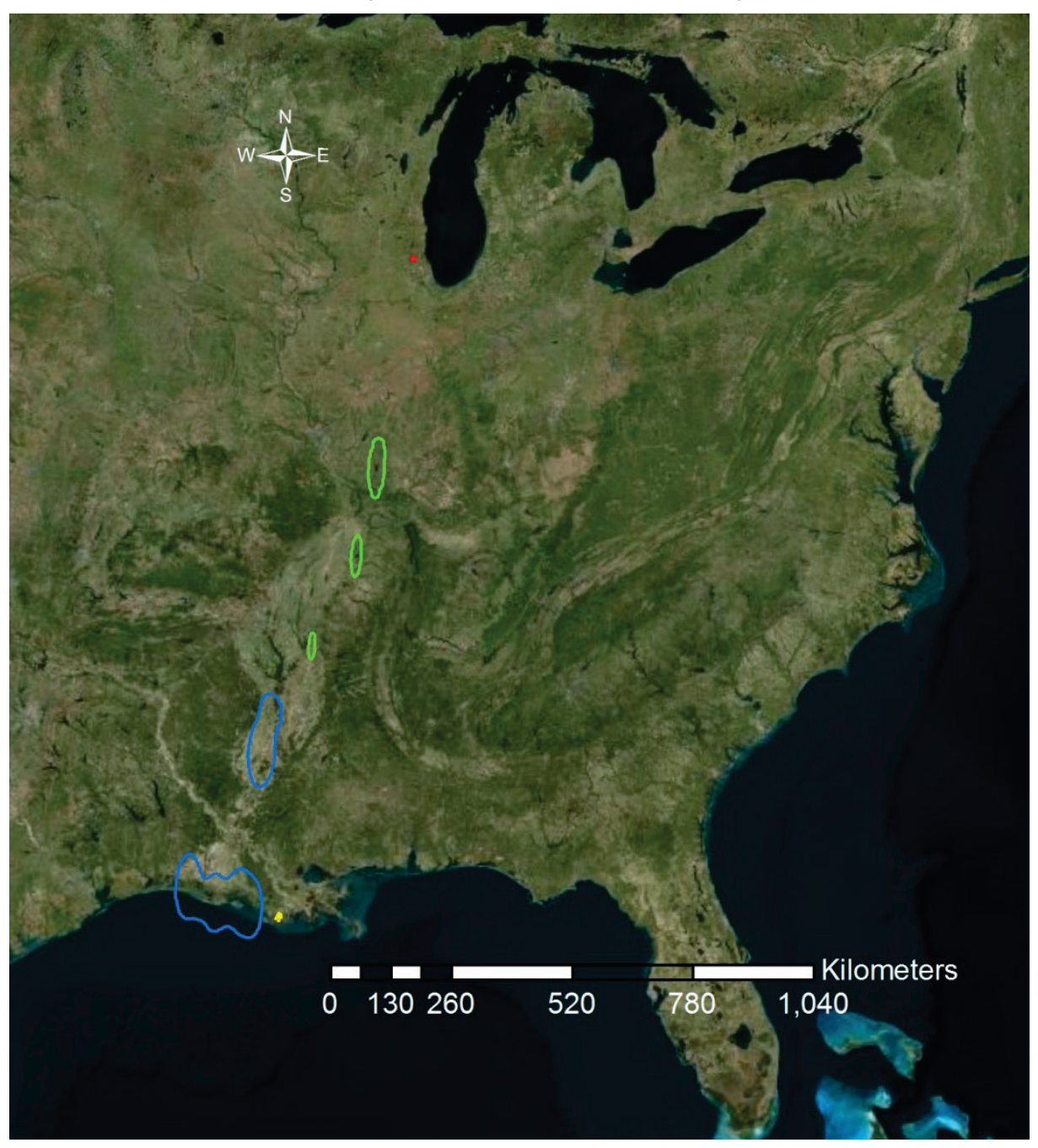


Figure B10. 50\% kernel home range polygons for 4 wintering cormorants from Baker's Lake, November 1 - December 24, 2012.

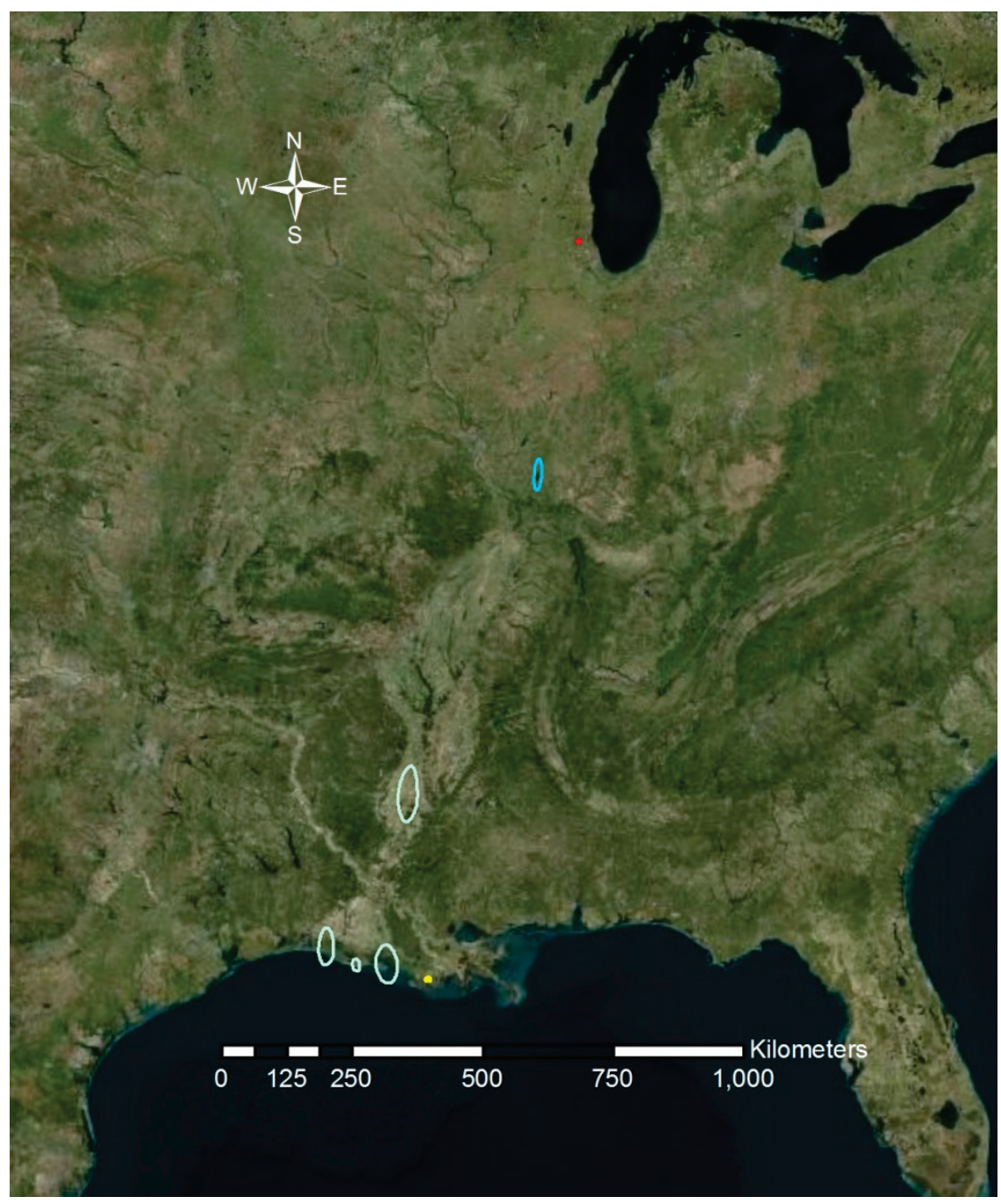


Figure B11. 95\% kernel home range polygons for 4 wintering cormorants from TNC Emiquon Preserve, November 1 - December 24, 2012.

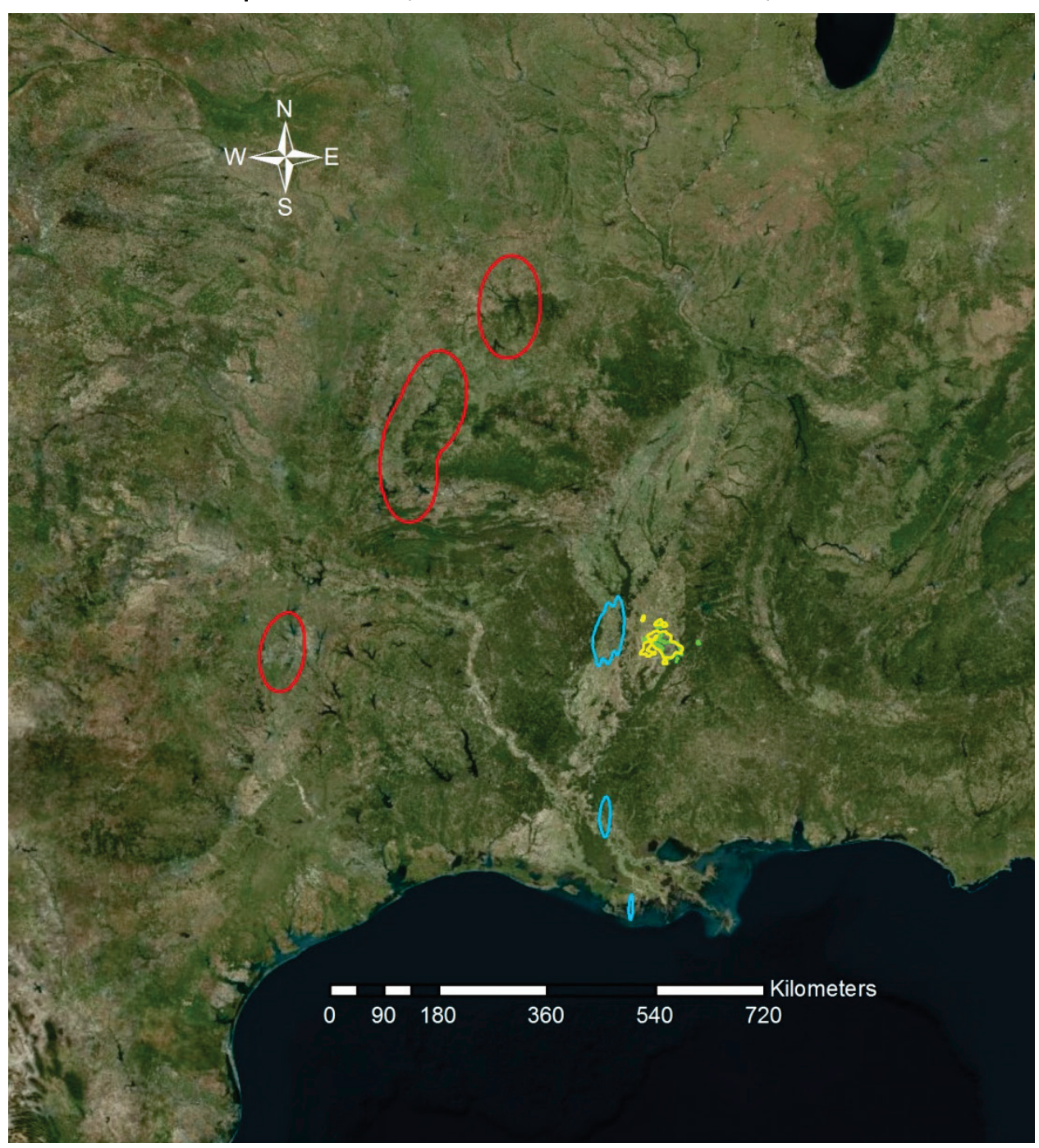


Figure B12. 50\% kernel home range polygons for 4 wintering cormorants from TNC Emiquon Preserve, November 1 - December 24, 2012.

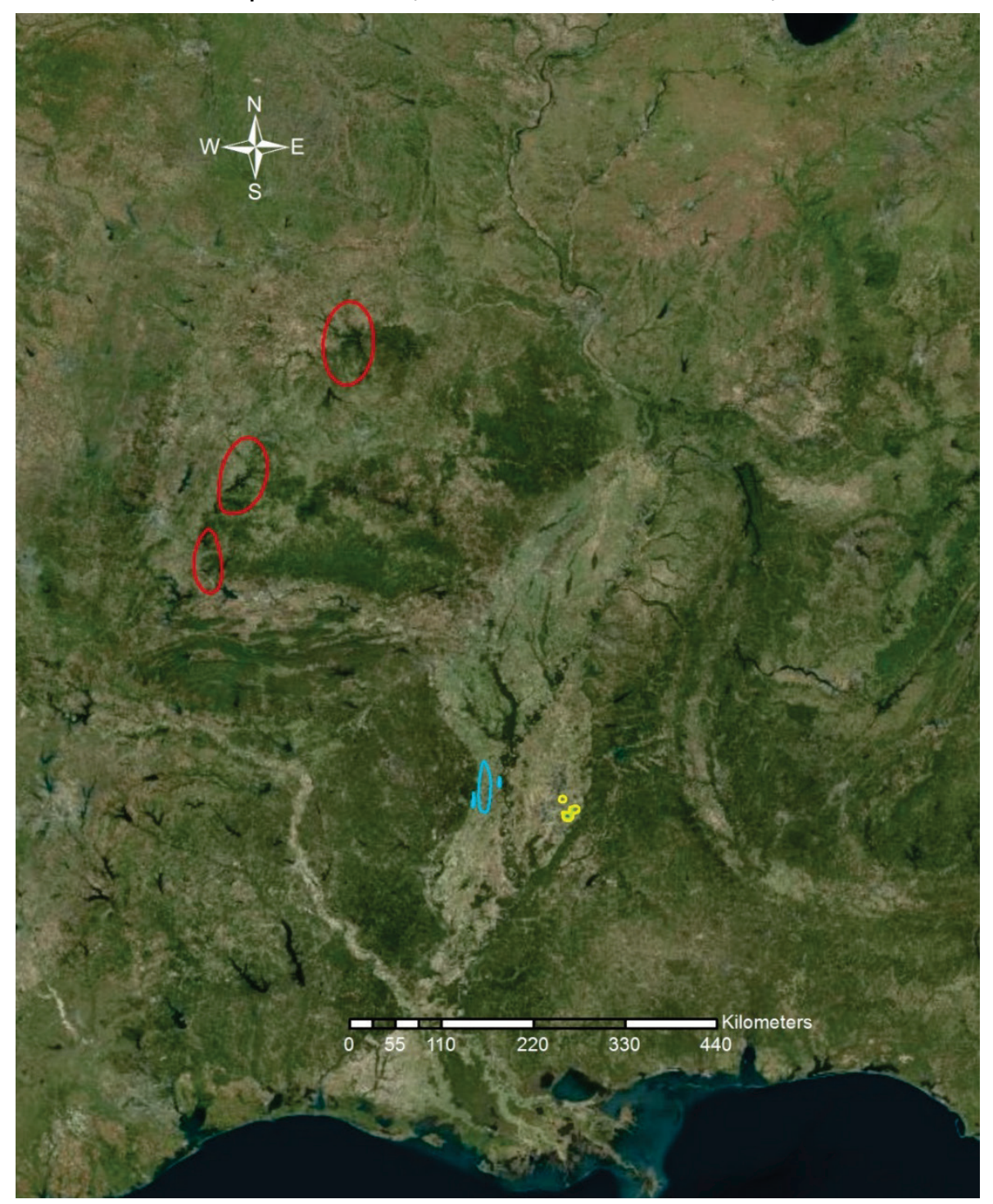




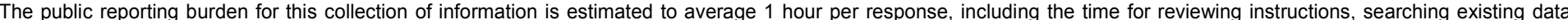

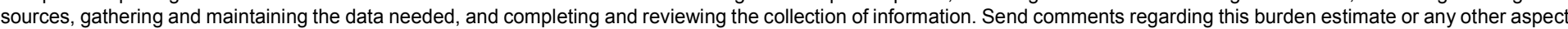

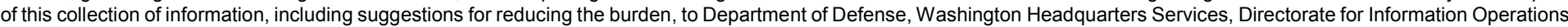

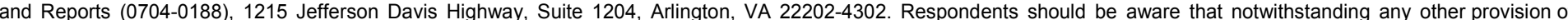
law, no person shall be subject to any penalty for failing to comply with a collection of information if it does not display a currently valid OMB control number.

PLEASE DO NOT RETURN YOUR FORM TO THE ABOVE ADDRESS.

\begin{tabular}{l|l|l|l}
\hline $\begin{array}{l}\text { 1. REPORT DATE } \\
\text { July } 2017\end{array}$ & $\begin{array}{l}\text { 2. REPORT TYPE } \\
\text { Final }\end{array}$ & 3. DATES COVERED (FrOm - To)
\end{tabular}

\section{TITLE AND SUBTITLE}

Documenting Presence and Movements of Piscivorous Birds along the Illinois River and within the Chicago Area Waterway System

\section{5a. CONTRACT NUMBER}

NOT ALL OF SECTION 5 IS APPLICABLE TO EVERY REPORT. SEE $2^{\text {ND }}$ PAGE OF THIS FORM.

\section{5b. GRANT NUMBER}

NA

\section{5c. PROGRAM ELEMENT NUMBER}

NA

\section{AUTHOR(S)}

Michael P. Guilfoyle, Brian S. Dorr, Katie Hanson-Dorr, Richard A. Fischer, and Anthony M. Friona

5d. PROJECT NUMBER

W81G6612907866

5e. TASK NUMBER

NA

5f. WORK UNIT NUMBER

33143

\section{PERFORMING ORGANIZATION NAME(S) AND ADDRESS(ES)}

Engineer Research and Development Center

3909 Halls ferry Rd, Vicksburg, MS 39180

USDA Wildlife Services, National Wildlife Research Center

Mississippi State University, MS

\section{SPONSORING/MONITORING AGENCY NAME(S) AND ADDRESS(ES)}

\section{PERFORMING ORGANIZATION REPORT NUMBER}

ERDC/EL TR-17-12

10. SPONSOR/MONITOR'S ACRONYM(S) CENAN

11. SPONSOR/MONITOR'S REPORT
NUMBER(S)
Not Applicable

Not Applicable

\section{DISTRIBUTION/AVAILABILITY STATEMENT}

Approved for public release; distribution is unlimited.

\section{SUPPLEMENTARY NOTES}

\section{ABSTRACT}

This technical report summarizes research conducted on piscivorous birds along the Illinois River and in the Chicago Area Waterway System (CAWS) to assess the potential role of these birds as vectors of invasive carp (bighead carp (Hypophthalmichthys noblis) and silver carp (H. molitrix)) DNA (deoxyribonucleic acid). To prevent invasive carp from invading the Great Lakes, the U.S. Army Corps of Engineers has spent considerable time and resources constructing electrical barriers in the Chicago Sanitary and Ship Canal around Romeoville, IL, just south of the Chicago metropolitan area. Since the construction of these barriers, intensive monitoring of fish populations and invasive carp environmental DNA (eDNA) have been used to document the possible presence of carp above the barrier. The Asian Carp eDNA Calibration Study (ECALS) was designed to improve our understanding and interpretations of eDNA monitoring efforts in the Chicago Area Waterway System (CAWS). Existing online bird population data sources were analyzed, and 30 DoubleCrested Cormorants (Phalacrocorax auritus) were captured and satellite-tagged. The results from these projects are evidence that piscivorous birds are likely contributing — at least in part - to the presence of invasive carp DNA in the Chicago Area Waterway System.

\section{SUBJECT TERMS}

Asian Carp eDNA Calibration Study (ECALS), CAWS, Double-Crested Cormorants, environmental DNA (eDNA), invasive carp, piscivorous birds, Piscivorous birds, Double-crested cormorant, DNA--Environmental aspects-Monitoring, Chicago (Ill.)--Water-supply, Carp, Fish populations, Bird populations, Illinois River (Ill.)

\begin{tabular}{|c|c|c|c|c|c|}
\hline \multicolumn{3}{|c|}{ 16. SECURITY CLASSIFICATION OF: } & \multirow{3}{*}{$\begin{array}{l}\text { 17. LIMITATION OF } \\
\text { ABSTRACT } \\
\text { SAR }\end{array}$} & \multirow{3}{*}{$\begin{array}{c}\text { 18. NUMBER } \\
\text { OF PAGES } \\
69\end{array}$} & \multirow[t]{2}{*}{ 19a. NAME OF RESPONSIBLE PERSON } \\
\hline 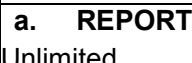 & b. ABSTRACT & $\begin{array}{ll}\text { c. } & \text { THIS PAGE } \\
\text { Unlimited }\end{array}$ & & & \\
\hline & & & & & 19b. TELEPHONE NUMBER (Include area code) \\
\hline
\end{tabular}

